DEPARTMENT OF COMMERCE

BUREAU OF. STANDARDS

George K. Burgess, Director

TECHNOLOGIC PAPERS OF THE BUREAU OF STANDARDS, NNo. 307

[Part of Vol. 20]

\title{
DURABILITY OF CEMENT DRAIN TILE \\ AND CONCRETE IN ALKALI SOILS: FOURTH PROGRESS REPORT \\ (1923)
}

\author{
BY \\ G. M. WILLIAMS, Consulting Engineer \\ IRVING FURLONG, Associate Chemist \\ Bureau of Standards
}

JANUARY 20, 1926

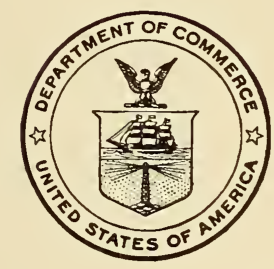

PRICE 20 CENTS

\$1.25 PER VOLUME ON SUBSCRIPTION

Sold only by the Superintendent of Documents, Government Printing Office Washington, D. C. 



\title{
DURABILITY OF CEMENT DRAIN TILE AND CON- CRETE IN ALKALI SOILS: FOURTH PROGRESS REPORT (1923)
}

\author{
By G. M. Williams and Irving Furlong
}

\section{ABSTRACT}

This paper reports the results of the inspection in 1923 of experimental draintile and concrete-block installations at eight alkali-bearing projects in the West. The investigation has been carried on since 1913, and the conclusions to date are that the best quality of concrete will disintegrate when exposed to severe alkali attack and that installations of concrete in soils containing more than 0.1 per cent of salts of the sulphate type should be preceded by an examination of surrounding conditions.

\section{CONTENTS}

I. Introduction

II. Early history of field investigation

1. Program and scope of drain-tile investigation

2. Program and scope of concrete-block investigation _._._. 195

3. Methods of field tests and inspections_._.

III. Summary of results of field inspection 198

1. Drain tile

2. Concrete blocks_... 224

IV. Summary of results

1. Drain tile

2. Concrete blocks__._. 235

V. Conclusions

1. Concrete blocks_._. 235

2. Cement drain tile

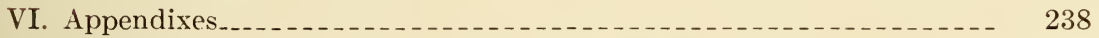

Appendix A.-Absorption tests on tile of series 1 to $21 \ldots$

Appendix B.- The presence and distribution of salts in the soil and their action on cement and concrete........ 238

\section{INTRODUCTION}

The field inrestigation of the durability of cement drain tile and concrete in alkali soils and waters was started in 1913 with the installation of drain-tile test specimens in 10 Western districts, followed in 1915 by the exposure of concrete blocks in 8 localities, some of which are the same in which drain tile were installed. Full details of the manufacture and installation of the drain tile, together with ground and soil water conditions, were included in a report prepared after the first inspection in 1914. This report (B. S. 
Tech. Paper No. 44) is now out of print. Following the installation of the concrete blocks in 1915 and the third inspection made in 1916, B. S. Technologic Paper No. 95 was prepared. In that report are included all the essential data of B. S. Technologic Paper No. 44. Owing to press of war work, no further investigation was made until 1919, when a third report, B. S. Technologic Paper No. 214 , was issued. The latter is designated as a "third progress report" and contains a very brief summary of the earlier history of the investigation included in full in B. S. Technologic Paper No. 95.

\section{EARLY HISTORY OF FIELD INVESTIGATION}

\section{PROGRAM AND SCOPE OF DRAIN-TILE INVESTIGATION}

The Bureau of Standards cooperative investigation of the durability of concrete in alkali soils and waters was started in 1913 to supplement a somewhat similar investigation relating to the use of concrete in sea water which was begun by the technologic branch of the United States Geological Survey and completed by the Bureau of Standards after the work of the former branch was turned over to the bureau in 1910 .

The sea-water concrete investigation showed conclusively that Portland cement could be disintegrated under laboratory conditions, but criticism was made that in practice concrete was proving durable where exposed to field conditions. To make observations on concrete of known quality under practical working conditions was the purpose of the present investigation. The cooperation of the United States Reclamation Service, Drainage Investigations of the United States Department of Agriculture, and what is now known as the Portland Cement Association was obtained, since these three organizations were greatly interested in the use of concrete in alkali soils. In 1919 this grouping was enlarged by the addition of the American Concrete Pipe Association and the Engineering Institute of Canada.

Test specimens in the form of drain tile were selected because they have comparatively thin walls, because they would be immersed in the ground water a considerable portion of the time, and because their position below the frost line would avoid the possibility of frost action complicating alkali action. Later, concrete blocks were prepared for exposure, so as to simulate the exposure conditions of larger masses, such as are employed by the Reclamation Service.

A program was drawn up which provided for the manufacture of 16 varieties or types of cement drain-tile, 8 inches in diameter and 12 inches long, to be installed in working drains in the Western States. To replace tile removed for test, five additional types were subsequently provided for installation in drains at intervals, as listed in Table 1. 
A list of all drain tile provided for test, as well as essential data relating to their manufacture, are included in Table 1 . The tile of the original series were manufactured during the summer of 1.913 at a commercial cement tile plant at Armstrong, Iowa. Good practice was followed in the manufacture of these tile and every precaution was taken to make as good and uniform tile as the proportions of materials used would permit.

After a curing period of at least one month carload shipments were made to certain places where they were installed in working drains.

Tile shipped to the following districts were installed in concentrated alkali soils where there was sufficient ground water available in the soil to result in flow during a portion of the year: Garland, Wyo.; Fort Shaw, Mont.; Huntington, Utah; Sunnyside, Wash.; Yuma, Ariz.; Roswell, N. Mex.; Grand Junction and Montrose, Colo.

To obtain comparative test data, shipments were also made to Crookston, Minn., and Columbia, Mo., where the tile would be exposed only to fresh water. Another shipment was made to Iowa State College, Ames, Iowa, for storage in the open, exposed to the atmosphere.

TABLE 1.-Schedule of mixtures and processes of manufacture of drain tile

\begin{tabular}{|c|c|c|c|c|c|c|}
\hline Installation & Series & $\begin{array}{c}\text { Pro- } \\
\text { por- } \\
\text { tions } \\
\text { cement- } \\
\text { sand } \\
\text { by vol- } \\
\text { uma }\end{array}$ & $\begin{array}{l}\text { Consist- } \\
\text { ency } 1\end{array}$ & Manufacture & Curing & Notes \\
\hline $\begin{array}{l}\text { Original installa- } \\
\text { tion. }\end{array}$ & $\begin{array}{r}1 \\
2 \\
3 \\
4 \\
\\
5 \\
6 \\
\\
7 \\
7 \\
\\
8 \\
9 \\
10 \\
11 \\
12 \\
13 \\
14 \\
15 \\
16\end{array}$ & $\begin{array}{l}1: 21 / 2 \\
1: 21 / 2 \\
1: 2 \\
1: 2 \\
1: 2 \\
1: 2 \\
1: 3 \\
1: 4 \\
1: 11 / 2 \\
1: 11 / 2 \\
1: 3 \\
1: 4 \\
1: 21 / 2 \\
1: 3 \\
1: 3 \\
1: 4\end{array}$ & 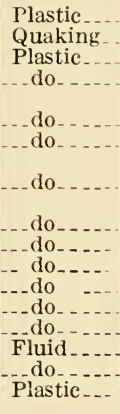 & 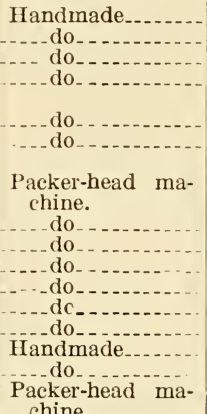 & 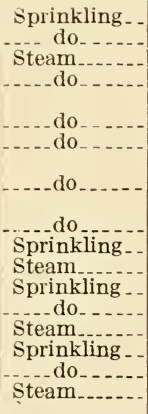 & $\begin{array}{l}\text { Dipped in cement } \\
\text { grout. } \\
\text { Dipped in hot tar. } \\
10 \text { per cent ferrous sul } \\
\text { phate in mixing water. }\end{array}$ \\
\hline 1914 replacement. & $\begin{array}{l}17 \\
18\end{array}$ & $\begin{array}{l}1: 1 \frac{1}{2} \\
1: 2\end{array}$ & $\begin{array}{l}\text { Quaking } \\
\text { do_..... }\end{array}$ & $\begin{array}{l}\text { On jigging ma- } \\
\text { chine. }\end{array}$ & Damp sand_ & $1 / 2$ inch maximum size \\
\hline 1915 replacement. & $\begin{array}{l}19 \\
20\end{array}$ & $\begin{array}{l}1: 21 / 2 \\
1: 21 / 2\end{array}$ & Plastic .... & Tamping machine. & $\begin{array}{l}48 \text { hours } \\
\text { steam. } \\
96 \text { hour s }\end{array}$ & \\
\hline 1919 replacement. & 21 & $1: 3$ & $\ldots$... do _. . ... & $\begin{array}{l}\text { Packer-head ma- } \\
\text { chine. }\end{array}$ & $\begin{array}{l}\text { steam. } \\
\text { Steam....... }\end{array}$ & Aggregate up to $1 / 2$ inch. \\
\hline
\end{tabular}

1 Plastic consistency $=$ damp sand consistency. As wet as would permit immediate removal of the jacket. Quaking consistency = not fluid, but wet enough to require retention in the molds for sereral hours. Fluid
consistency $=$ soupy mixture which was easily poured from a bucket. 


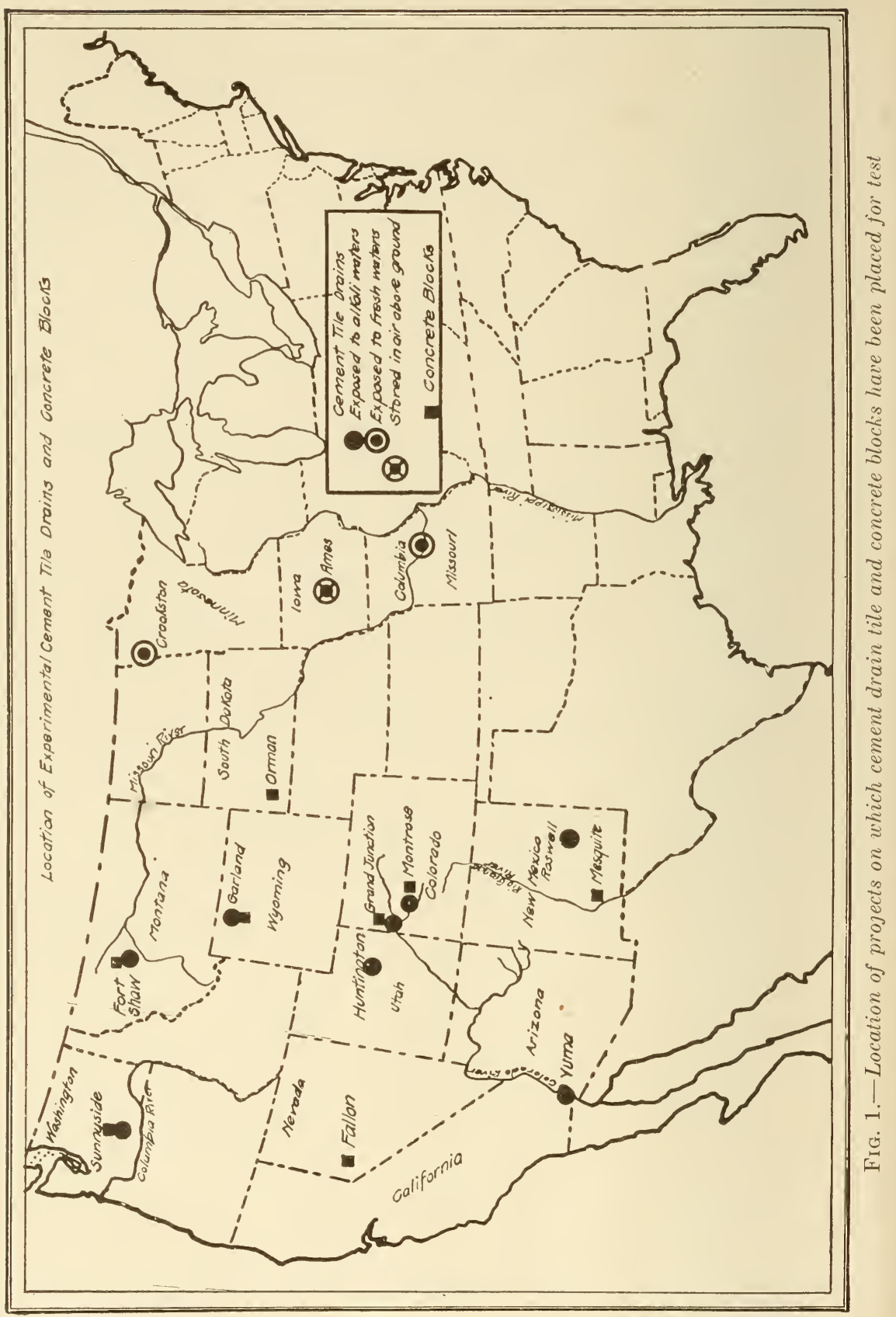


Referring to the tile used in the original installation of 1913, as listed in Table 1, it will be seen that proportions varied from 1 cement$11 / 2$ agregregate to 1 cement -4 aggregate. For most series a plastic consistency was employed which was as wet as could be used with the packer-head machine and yet permit the immediate removal of the jacket. The hand-tamped tile were molded in sheet-metal forms. Series 2 was molded of a quaking consistency mortar which was sticky and slightly flowable, requiring that the forms be kept in place for several hours. Series 14 and 1.) were of a soupy, creamy consistency, which was poured from a bucket. Series 3 to 6 , inclusive, were similar as to cement and aggregate content but received different treatments after molding. Series 4 was dipped in neat cement grout after 24 hours, series 5 was dipped in hot coal-tar pitch after 30 days, while 10 per cent ferous sulphate by weight was used in the mixing water of series 6. Steam-cured tile were exposed to exhaust stean for a total period of 96 hours. 'The water-cured tile were held in the curing rooms for a period of 12 days, during which time they were sprinkled twice daily without exposure to steam.

To replace tile removed for test in 1911 , series 17 and 18 tile were manufactured and furnished by the Lniversal Portland ('oment ('o., Chicago, III.

Series 19 and 20 tile used for replacement in 1915 were manuactured by the Utah (oncrete Pipe Co., Salt Lake ('ity, Ltah.

In 1919 tile removed for test were replaced by series 21 tile, manufactured by the Zeidler Concrete Pipe Co., Muscatine, Iowa, and furnished by the American Concrete Pipe Association.

Location of the drains and concrete block sites in the Western States are shown in Figure 1, and the distribution of the various types of the tile in each drain for convenience of removal for test is shown in Figure 2.

\section{PROGRAM AND SCOPE OF CONCRETE-BLOCK INVESTIGATION}

'To determine the effect of alkali waters on concrete placed above and below the ground line, a large number of concrete blocks were molded and installed in 1915. In order that actual ficld conditions might be duplicated, blocks of concrete 10 inches square and $21 / 2$ fect long were provided, to be placed rertically, with the lower end embedded in the ground to a depth of 1 foot. Two vertical steel reinforeing rods were placed in each block, 2 inches from each fare, and a third rod formed a loop projecting from the top which aided in handling. One series of blocks was molded at Denver, a central point, where an excellent quality of aggregate was available, in order to insure a uniform and good quality of concrete. Representative lots of these blocks were shipped to all projects where 

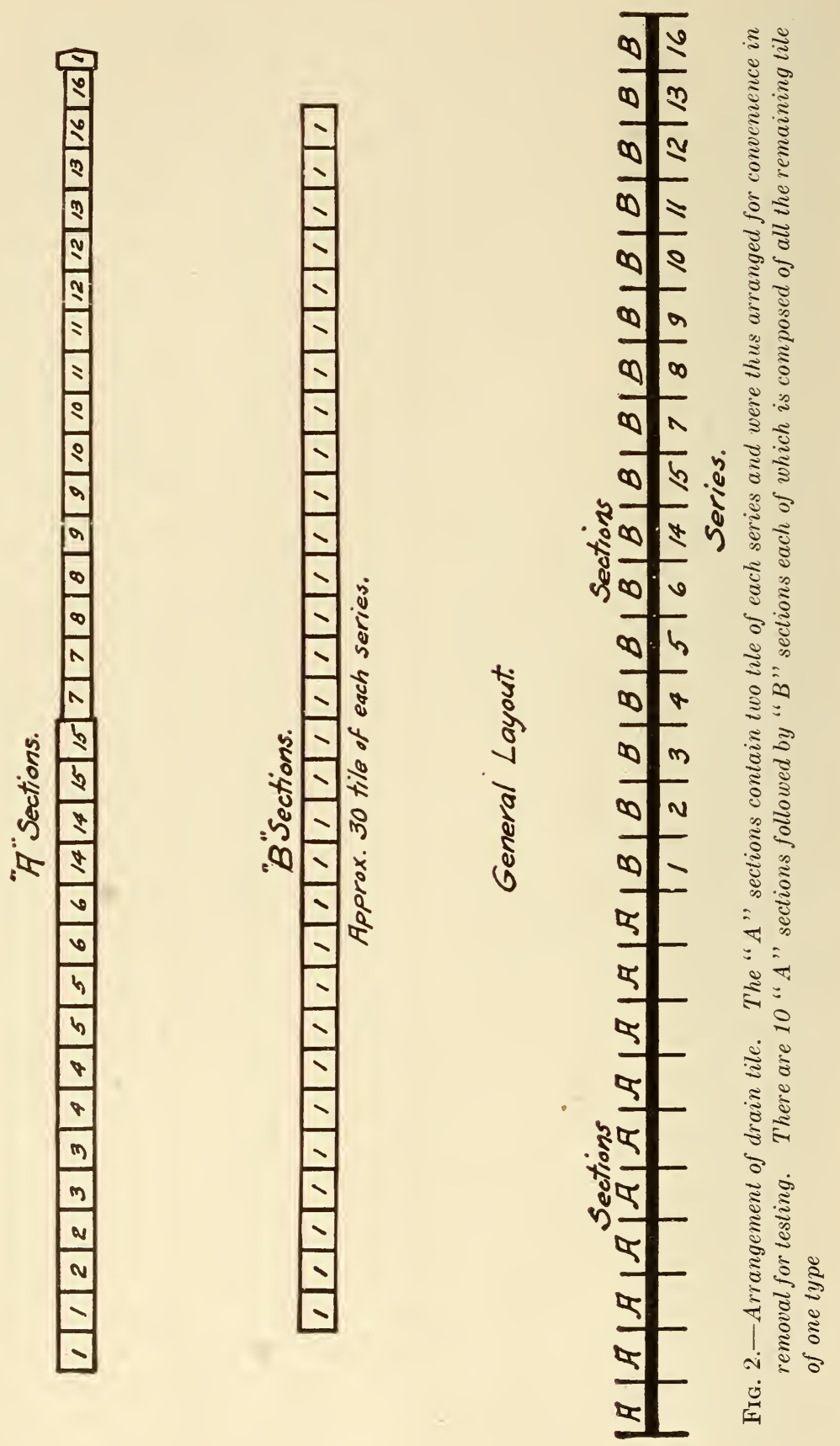
tests were to be made. Another series of similar blocks was molded at each project and after curing for 30 days was set in place in the soil, while a third series was molded in place immediately exposed to alkali water. At each project the cement in use there was used and the aggregates were of those then available in commercial quantities near the site of construction work on the projects.

The manufacture of one set of blocks at Denver insured a good quality of concrete which would be installed on all projects, thereby permitting direct comparisons to be made of the severity of alkali action at the block sites of the different projects, as well as to gire an idea of the relative qualities of the many concretes made with local materials. Concrete blocks were manufactured and installed at Orman, S. Dak.; Powell, Wyo.; Fort Shaw, Mont.; Sunnyside, Wash.; Falion, Ner.; Mesquite, N. Mex.; Montrose and Grand Junction, Colo.

In the following table is shown a list of concrete blocks manufactured and installed on each project:

TABLE 2.- List of concrete blocks molded and installed in 1915

[All blocks molded in smooth wood molds unless otherwise indicated. Blocks are 10 by 10 inches square and 30 inches long]

\begin{tabular}{|c|c|c|c|c|c|c|}
\hline \multirow{3}{*}{ Place of installation } & \multirow{2}{*}{\multicolumn{2}{|c|}{$\begin{array}{l}\text { Molded at Denver: } \\
\text { A series (propor- } \\
\text { tions by vol- } \\
\text { ume) }\end{array}$}} & \multicolumn{4}{|c|}{ Molced at project } \\
\hline & & & \multicolumn{2}{|c|}{$\begin{array}{c}\text { Central yard B } \\
\text { series (propor- } \\
\text { tion by volume) }\end{array}$} & \multicolumn{2}{|c|}{$\begin{array}{l}\text { In place in alkali } \\
\text { soil C series (pro- } \\
\text { portion by vol- } \\
\text { ume) }\end{array}$} \\
\hline & $1: 11 / 2: 3$ & $1: 21 / 2: 5$ & $1: 1 / 2: 3$ & $1: 21 / 2: 5$ & $1: 1 \frac{1}{2}: 3$ & $1: 21 / 2: 5$ \\
\hline Orman, S. Dak . - & $\begin{array}{rl} & 2 \\
1 & 2 \\
2 & 2\end{array}$ & $\begin{array}{rl} & 2 \\
1 & 2 \\
2 & 2\end{array}$ & 2 & 2 & 2 & 2 \\
\hline Powell, Wyo_... & $\begin{array}{rl} & 2 \\
1 & 2 \\
2 & 2\end{array}$ & $\begin{array}{rl} & 2 \\
1 & 2 \\
2 & 2\end{array}$ & 2 & 2 & 2 & 2 \\
\hline $\begin{array}{l}\text { Fort Shaw, Mont } \\
\text { Sunnyside, Wash } \\
\text { Mesquite, N. Mex. } \\
\text { Fallon, Nev } \\
\text { Montrose, Colo. }\end{array}$ & $\begin{array}{l}2 \\
2 \\
2 \\
2 \\
2\end{array}$ & $\begin{array}{l}2 \\
2 \\
2 \\
2 \\
2\end{array}$ & $\begin{array}{l}2 \\
2 \\
2 \\
2 \\
2\end{array}$ & $\begin{array}{l}2 \\
2 \\
2 \\
2 \\
2\end{array}$ & $\begin{array}{l}2 \\
2 \\
2 \\
2 \\
2\end{array}$ & $\begin{array}{l}2 \\
2 \\
2 \\
2 \\
2\end{array}$ \\
\hline Grand Junction, Colo. ${ }^{3}$ & $\begin{array}{rl} & 2 \\
1 & 2 \\
2 & 2\end{array}$ & $\begin{array}{rl} & 2 \\
1 & 2 \\
2 & 2\end{array}$ & $\begin{array}{c}2 \\
-\end{array}$ & 2 & $\begin{array}{r}2 \\
-\end{array}$ & 2 \\
\hline
\end{tabular}

1 Molded in steel-lined molds.

2 Molded in rough-wood molds.

3 Blocks of both proportions of sand cement concrete and natural cement concrete were also molded at ${ }^{3}$ Blocks of both proportions of sand cemen
Denver for installation at Grand Junction.

Throughout the block work care was taken to produce the best possible quality of concrete. All materials were weighed to insure accuracy and thoroughly mixed by shoveling in batches sufficiently large for a single block. Sufficient mixing water was used to result in a plastic quaking concrete which handled and placed easily. For

$$
56960^{\circ}-26 \dagger-2
$$


the Denver blocks equal quantities of water were used for all blocks of the same proportion. The same procedure was followed at each project. The consistency was not fluid, as is commonly used in reinforced concrete construction work, and was probably slightly stiffer than could be used in many structures.

With the variations in brands and constituents of Portland cement used and with the different gradations of aggregates available on the different projects, a large variety of concretes were obtained. Full records were kept of quantities of cement, sand, gravel, and water used, and samples of each were obtained for complete laboratory tests and analyses.

\section{METHODS OF FIELD TESTS AND INSPECTIONS}

As indicated in Figure 2, the tile originally installed were so grouped that excaration of a continuous trench 32 feet long would allow the removal of a section consisting of 2 each of the 16 types. Field tests made in 1914, 1915, 1916, 1919, and 1923 consisted of the removal of one or more such sections and crushing tests made near the drain by means of a portable hydraulic tile testing machine which was designed and built at the bureau. Samples of all broken tile were obtained and observation was made as to the conditions of each, such as apparent amount of moisture and white salts in the walls. Samples of soils and waters were obtained for chemical analysis. During the early part of the investigation water samples were also obtained for analysis each spring.

The concrete blocks were inspected in 1916, 1919, and 1923. This consisted of visual inspection of each block above and below the water or ground line. Samples of soil waters to which the blocks were subjected were secured for chemical analysis.

\section{SUMMARY OF RESULTS OF FIELD INSPECTION}

\section{DRAIN TILE}

The inspection made in the fall of 1923 of drain tile laid in 1913 completed the original program for a study of durability over a 10-year period.

In Table 6, page 320, are listed the individual results of crushing tests made at the several projects in 1923 . Table 7 , page 321 , contains a summary of all crushing test results made during the 10 years of drain-tile exposure.

Since the resistance of the tile to alkali action was found to vary more generally with the consistency of the mixture and with the method of manufacture, the following grouping is made for convenience of reference:

Group A.-Plastic consistency, machinemade. Series 8, 12, and 16 (proportions 1:4), series 7, 11, and 21 (proportions $1: 3$ ), series 13, 19, and 20 (proportions $1: 2 \frac{1}{2}$ ) and series 9 and 10 (proportions $1: 1 \frac{1}{2}$ ). 
Group B.-Plastic consistency, handmade. Series 1 (proportions $1: 21 / 2$ ), series $3,4,5$, and 6 (proportions $1: 2$ ).

Group C.-Quaking consistency, handmade. Series 2 (proportions $1: 21 / 2$ ), series 18 (proportions $1: 2$ ) and series 17 (proportions $1: 1 \frac{1}{2}$ ).

Group D.-Fluid consistency, handmade. Series 14 (proportions $1: 3$ ) and series 15 (proportions 1:3 using sand cement).

Group A, Plastic Consistency, Machinemade Tile.-At the end of three years of exposure the leaner mix specimens of this group showed the presence of alkali within tile wall and with disintegrating effects on some members of the $1: 4$ proportioned mixes (series 8,12 , and 16) at five of the eight alkali projects. At the end of $10-$ year exposure the $1: 4$ mix type as a unit had escaped some degree of disintegration at only two of the alkali projects. At only three of the alkali projects, where exposure conditions were particularly severe, were some members of the $1: 3$ type of mix affected. These series $(7,11$, and 21$)$ as a unit first show disintegration in series 21 at the end of the fourth year with condition of the grouping unit progressively somewhat worse at the end of the tenth year. Series 13, 19, and 20 (the $1: 2 \frac{1}{2}$ type of mix) were more resistant to attack, series 13 only showing disintegration at one project during the 10 -year period observed during the third year. The richest type of mix represented in the grouping (proportions $1: 1 \frac{1}{2}$ ) represented in series 9 and 10 showed disintegration in only one instance throughout the entire 10 years of exposure. Within the range of study this grouping shows that in tile of plastic consistency, made on the packerhead type of machine, relative resistance to alkali attack increases with richness of the mix.

Group B, Plastic Coxsistency, Handmade Tile.-Tile of this group were generally found to contain salts within tile wall after three years of exposure at all projects where exposed to alkali water. In some cases cracking and swelling were observed at the third year period. At the end of the tenth year at least one tile from each series had undergone more or less disintegration at one of the alkali projects. None of these tile were made of a mixture leaner than 1 part Portland cement to $2 \frac{1}{2}$ parts sand. The inefficiency of hand tamping of a plastic or dry mixture is clearly shown by these tile. The resistance of these tile to alkali exposure is apparently no greater than that of the leanest mixture of Group A. No positively beneficial effects have resulted from the addition and the use of ferrous sulphate in the mixing water of series 6 , or by a coating of neat cement grout (series 4), or by a coating of tar (series 5). While the coatings of series 4 and 5 have had some apparent beneficial effects in retarding action of waters of low concentration, the retarding action appears to be negligible where concentrations are high.

Group C, Quaking Consistency, Handmade.- The tile of proportions 1 part cement to $2 \frac{1}{2}$ sand (series 2) were hand tamped 
and those of proportions 1 part cement to 2 parts sand (series 17 and 18) were made on a jigging device. The type of tile represented by series 2 permitted but slight permeation of alkali waters into tile wall. Only at one alkali project where a reserve supply of series 2 tile was embedded in alkali-bearing shale was incipient disintegration observed. Series 17 and 18 also have proved relatively impervious to alkali water, though susceptible to surface attack. At the end of five years' exposure surface attack at two projects harl progressed to the point of partial disintegration of the specimens of both series, but the conditions effecting this rapid action were severe.

Group D, Fluid Consistency, Handuade.--In this group are included series 14, 1 part cement to 3 parts sand, and series 15,1 part sand cement to 3 parts sand. The sand-cement tile have eridenced alkali salts in the tile wall, and in numerous cases during the 10 years have shown a softening of the walls and disintegration, even during the first year of exposure to severe conditions. Series 14, most nearly comparable with series 2 of Group C, was usually found to be nearly dry within tile wall when tested during the early exposure periods. At the end of three years' exposure in contact with high concentrations of alkali salts were observed in the tile walls, and 10 years' exposure to such environment effected partial disintegration.

As one of the purposes of the investigation was to define the durability of cement drain tile in terms of aikali environment, there are given in Table 3 the average amount and composition of soluble salts in the water flowing through the several drain-tile installations during the 10-year exposure period.

TABLE 3.-Analyses (percentage reacting values) of waters in experimental drains [For explanation of reacting values and method of calculations see B. S. Tech. Paper No. 95, pp. 37-43]

\begin{tabular}{|c|c|c|c|c|c|c|c|c|c|}
\hline \multirow{2}{*}{ Location } & \multicolumn{3}{|c|}{$\begin{array}{l}\text { Per cent soluble solids } \\
\text { in water }\end{array}$} & \multicolumn{6}{|c|}{ Percentage reacting values } \\
\hline & $\begin{array}{l}\text { A ver- } \\
\text { age }\end{array}$ & $\begin{array}{l}\text { Maxi- } \\
\text { mum }\end{array}$ & $\begin{array}{l}\text { Mini- } \\
\text { mum }\end{array}$ & $\mathrm{Na}$ & $\mathrm{Ca}$ & $\mathrm{Mg}$ & $\mathrm{Cl}$ & $\mathrm{SO}_{4}$ & $\mathrm{CO}_{3}$ \\
\hline $\begin{array}{l}\text { Garland, W yo } \\
\text { Fort Shaw, Mont-. } \\
\text { Sunnyside, Wash } \\
\text { Yuma, Ariz }\end{array}$ & $\begin{array}{l}0.22 \\
.15 \\
.27 \\
.13\end{array}$ & $\begin{array}{r}0.49 \\
.54 \\
.58 \\
.19\end{array}$ & $\begin{array}{l}0.12 \\
.12 \\
.18 \\
.07\end{array}$ & $\begin{array}{l}33.3 \\
26.0 \\
28.4 \\
24.2\end{array}$ & $\begin{array}{r}9.5 \\
6.6 \\
11.0 \\
15.0\end{array}$ & $\begin{array}{r}7.2 \\
17.4 \\
10.6 \\
10.8\end{array}$ & $\begin{array}{r}2.0 \\
1.0 \\
6.5 \\
15.3\end{array}$ & $\begin{array}{l}35.8 \\
29.2 \\
35.1 \\
17.1\end{array}$ & $\begin{array}{r}12.2 \\
19.8 \\
8.4 \\
17.6\end{array}$ \\
\hline $\begin{array}{l}\text { Roswell, N. Mex } \\
\text { Montrose, Colo } \\
\text { Grand Junction, Colo-.-. } \\
\text { Huntington, Utah. }\end{array}$ & $\begin{array}{r}.48 \\
.45 \\
.44 \\
.30\end{array}$ & $\begin{array}{r}.50 \\
1.01 \\
1.10 \\
.49\end{array}$ & $\begin{array}{l}.42 \\
.23 \\
.13 \\
.24\end{array}$ & $\begin{array}{r}24.7 \\
9.8 \\
23.3 \\
18.3\end{array}$ & $\begin{array}{l}18.9 \\
27.3 \\
14.5 \\
20.1\end{array}$ & $\begin{array}{r}6.4 \\
12.9 \\
12.2 \\
11.6\end{array}$ & $\begin{array}{r}27.6 \\
.3 \\
16.2 \\
1.8\end{array}$ & $\begin{array}{l}19.5 \\
46.7 \\
28.4 \\
40.8\end{array}$ & $\begin{array}{l}2.9 \\
3.0 \\
5.4 \\
7.4\end{array}$ \\
\hline
\end{tabular}

Regional operating drainage systems were installed at the site of several of the experimental drain locations and furnished an outlet for the leaching, percolating ground water, from either natural or irrigation sources. This resulted in a gradual reduction of alkali concentration in both the soil thus affected and the water draining 
from such soil. With gradual reduction of alkali concentration in the soil thus effected, there also occurred a gradual reduction of alkali concentration in the water draining from such soil. In general, therefore, the maximum concentration of dissolved alkali in drain water from any one experimental drain was recorded during the early exposure periods, while the minimum concentration was found during the tenth year.

Although there was, in general, a gradual reduction of concentration of alkali in drainage water, little variation is shown in the relative quantities of the constituents dissolved in the water of any one experimental drain. Table 4, recording analyses of all water samples taken at the outlet of the Garland, Wyo., test drain, indicates the typical constancy of composition during the 10-year period of gradual reduction in concentration of dissolved solids.

TABLE 4.-Analyses (percentage reacting values) of all water samples taken at outlet of Garland, Wyo., experimental drain

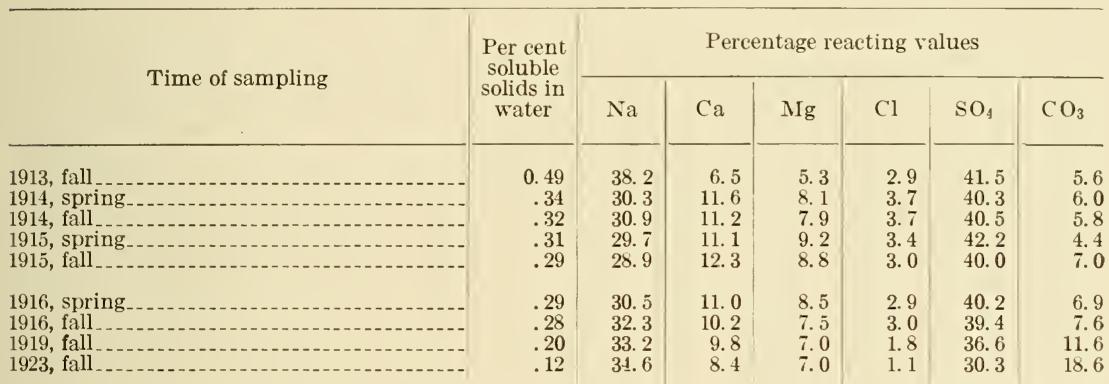

The analyses ot a number of soil samples secured in 1919 immediately in contact with tile which were badly disintegrated aid in emphasizing that concentrations to which individual tile may be exposed may be greatly in excess of the arerage concentrations as determined by analyses of water samples taken a short distance below at the outlet. These results are shown in Table 5. The analyses of the three soil samples from locations only a few feet apart at Fort Shaw illustrate the wide differences in salt content which may be found. The presence of orer 5 per cent soluble salt in the soil immediately abore a tile is certain to result in high concentrations when sufficient seepage water is present. These results indicate how greatly the salt content of the soil raries only a few feet apart and are of special value in pointing out how misleading the analyses of a single sample may be.

Garland, Wyo. - At the time of installation of the experimental drain at this location the site chosen showed much surface eridence of alkali. Figure 3 illustrates this feature. During the first year of installation the water flowing through the drain carried the highest recorded concentrations of dissolved salts. At the end of three 
rears' exposure tile series 12 and 16 of Group A showed evidences of deterioration. In the meanwhile heary local irrigation was rapidly reducing the severity of alkali enrironment. At the end of

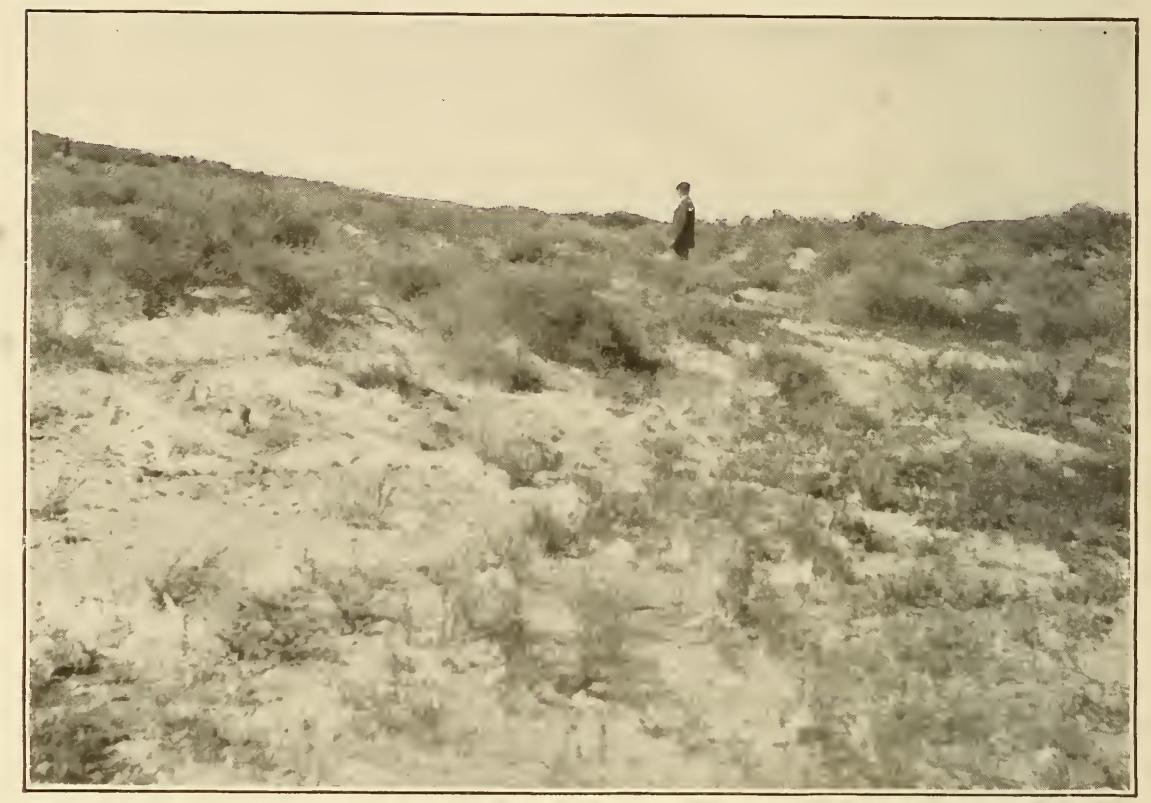

FIG. 3.- Site of experimental drain, lower end, at Garland, Wyo., showing heavy incrustations of alkali on surface and character of the vegetation. This site is usually swampy from seepage water, and the alkali concentration may be considered as bad as any to be found in the State

10 years' exposure the concentration of dissolved salts in drain water was reduced to about a quarter of the initial value. Most of the tile accumulated salts within the tile wall, but during the 10-year exposure period only series 12 and 16 showed disintegration.

TABLE 5.-Analyses (percentage reacting values) of waters, soils, and alkalies from drains in 1919

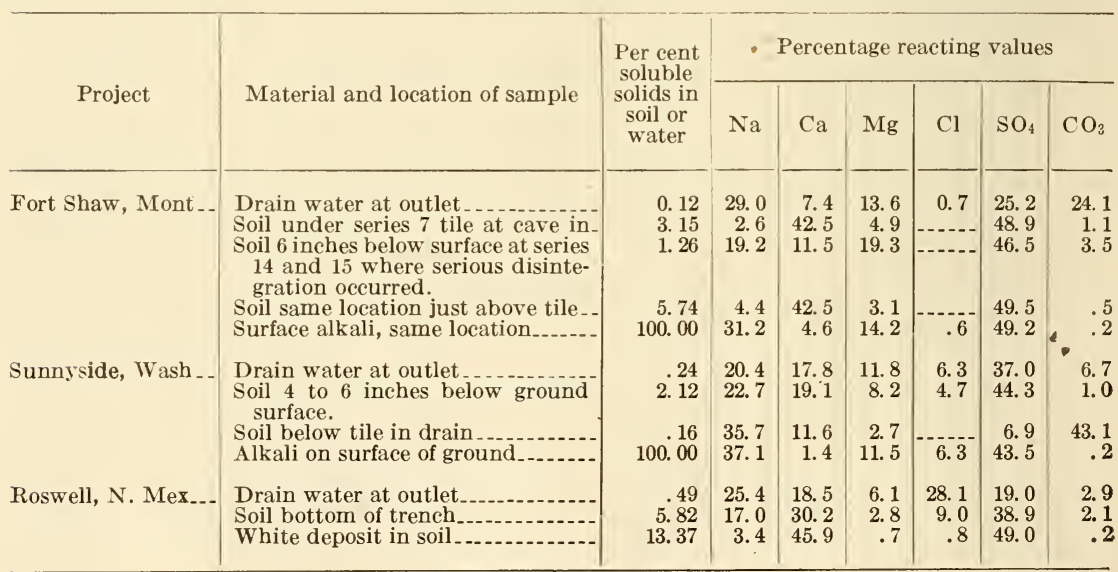


Fort Shaw, Mont.-At Fort Shaw a location for the tile was found just above an alkali lake, where the tile would also be of some service in draining an upper swamp. Figures 5 and 6 illustrate the site. As in the case of the Garland, Wyo., experimental drain, the highest concentration of dissolved salts in drain water was found during the first year of operation. With the exception of observed deterioration to series 13 and 16 tile after 10 years of exposure, the arerage concentration of the soluble salts in this drain water has not affected the tile excavated for examination further than to accumulate as a white

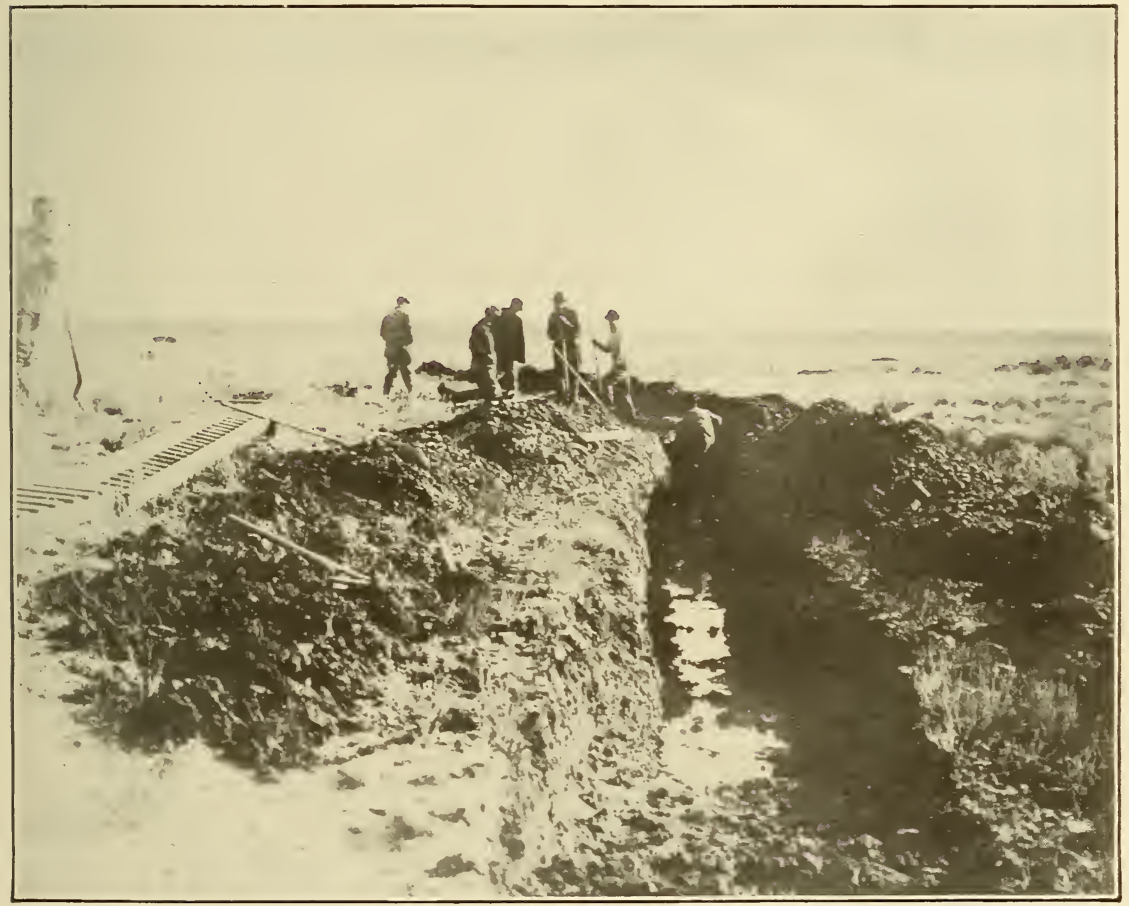

FIG. 4.-View of opened ditch at silt basin experimental drain at Garland, Iryo., showing the gravel soil and seepage water in the trench above the grade of the drain; also the wooden cradles shown on the left upon which the tile were placed

deposit within tile wall. Toward the outlet end of the line relatively close to the alkali lake a collapse of tile was discorered in the line after six years of exposure. Samples of soil taken either in contact with or just above collapsed tile were relatively rich in alkali content as recorded in Table 5. The condition of the tile in this portion of the drain indicated that samples of the drain water taken at the outlet of the line were not representative of the concentrations which had been present locally in the soil immediately surrounding some of the tile. 
Sunnyside, Wash.-In many respects the location of the Sunnyside, Wash., drain line resembled the Fort Shaw, Mont., site. Figures 7 and 8 indicate that a portion of the Sunnyside installation extended

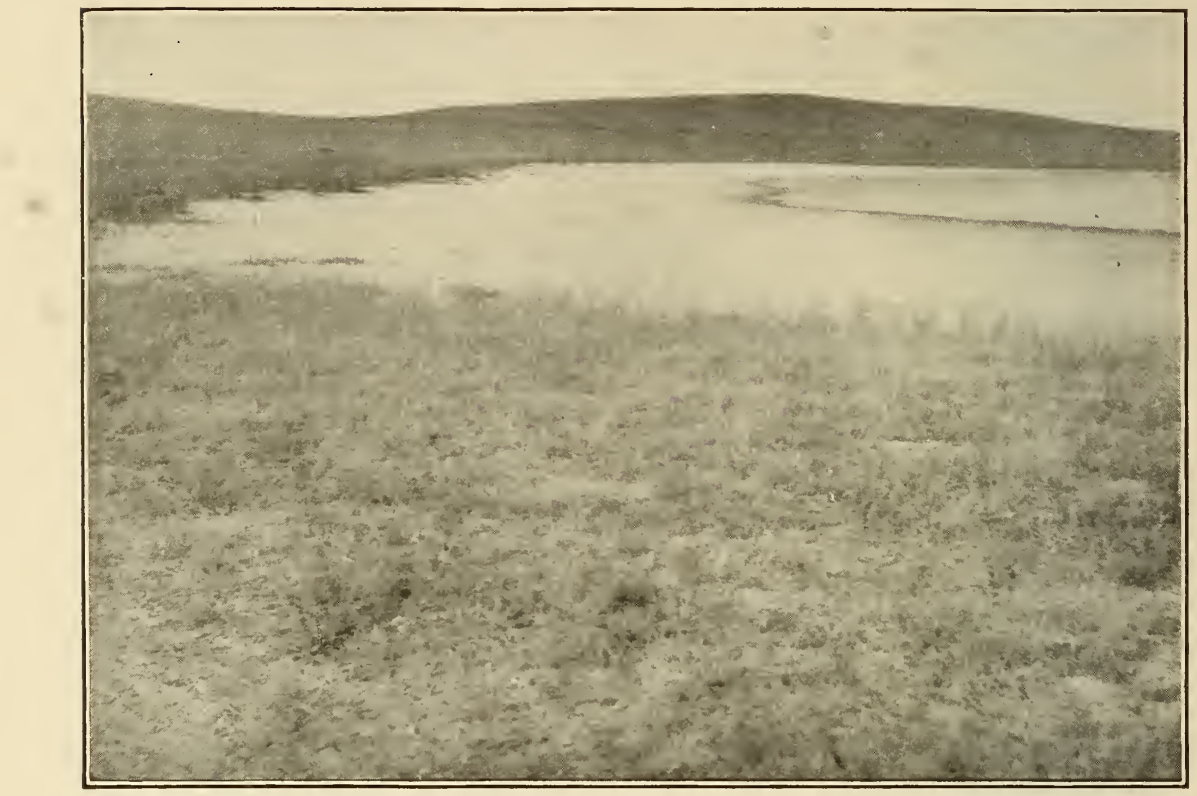

FIg. 5.-Alkali Lake at Lower end of experimental drain at Fort Shaw, Mont., showiug the heavy alkali deposits surrounding the lake

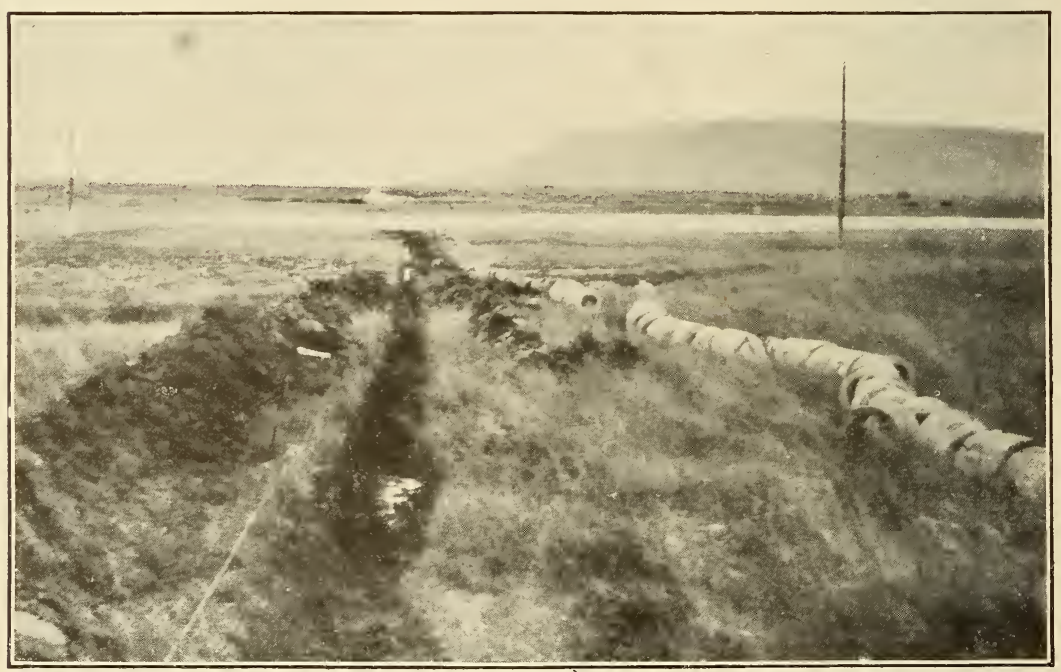

FIg. 6.- Site of experimental drain at Fort Shaw, Mont., looking toward lower end, showing the partially excavated trench and alkaline seepage water collecting in the bottom; also alkali weed covering the site 


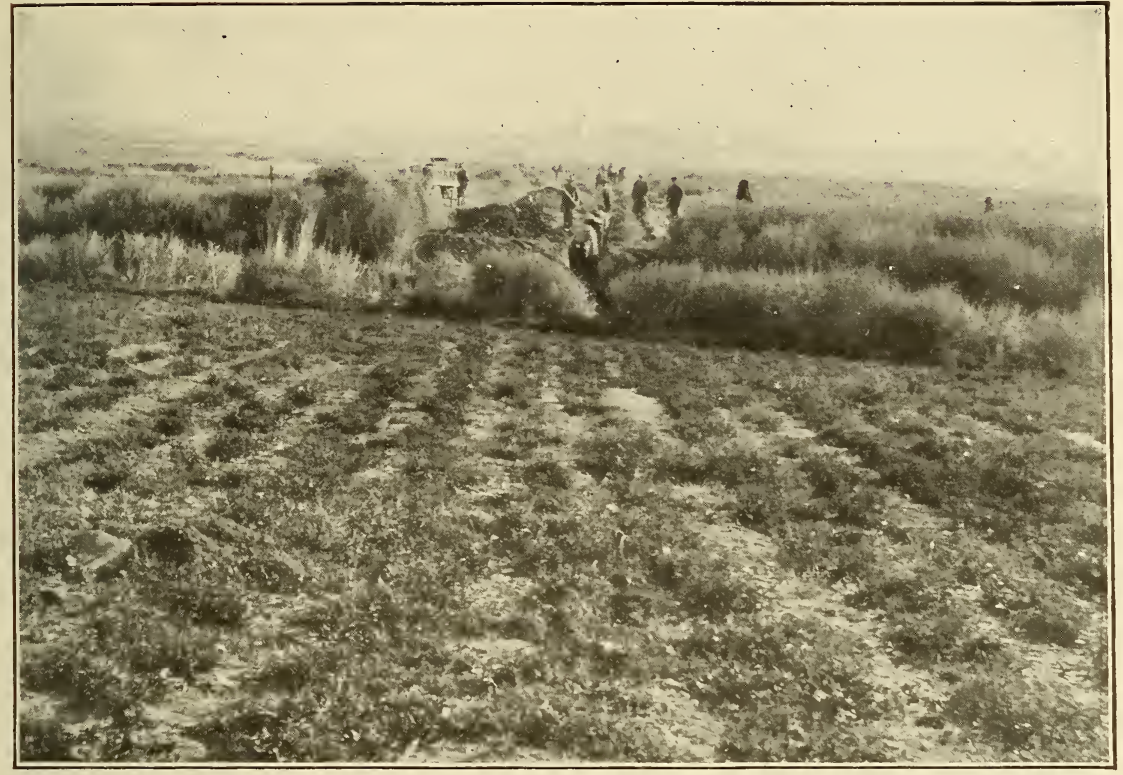

FIG. 7.-Opening lower end of ditch far experimental drain at Sunnyside, Wash., showing partially excavated trench. Note amount vegetation as compared with that in Fig. 8

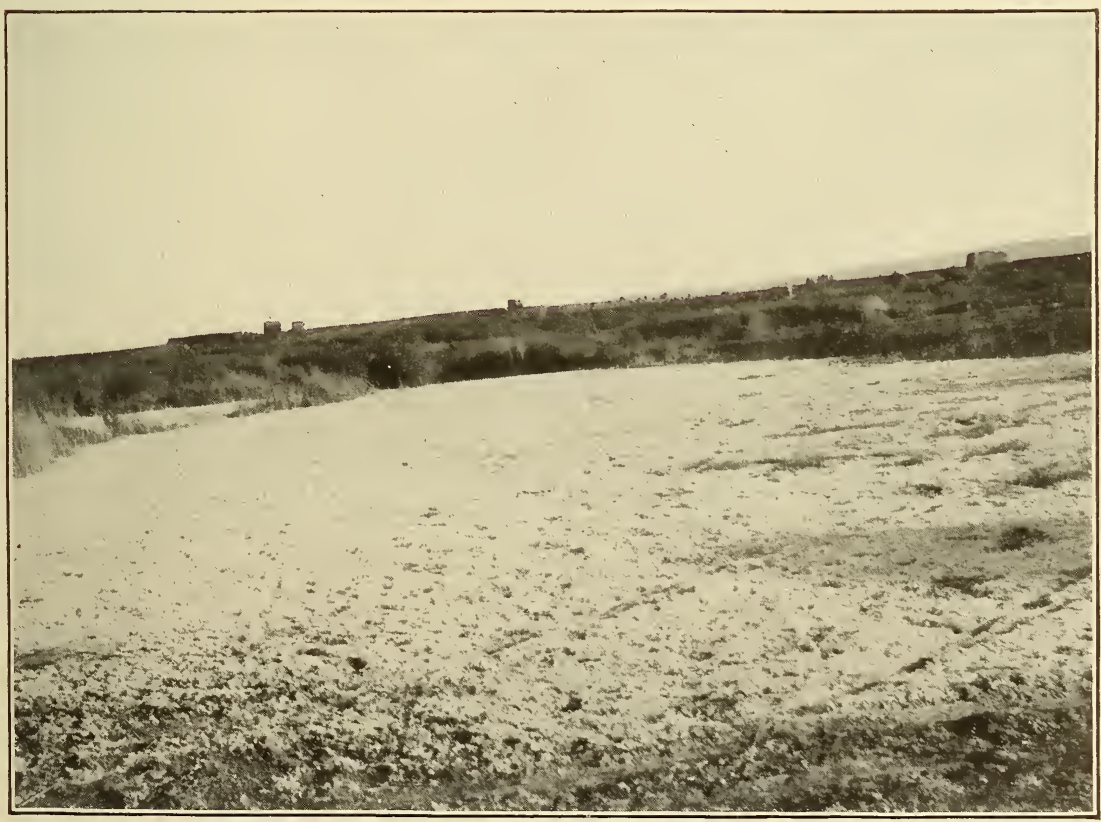

FIG. 8.-Upper end of site of experimental drain at Sunnyside, Wash., showing lack of vegetation and heavy alkali crust on surface of ground. The salts appear much more concentrated on the surface at the upper end than at the lower end $56960^{\circ}-26 \dagger-3$ 
into soil visibly impregnated with alkali salts. As was typical of operating drain tile installations, the alkali was gradually leached out of the soil with a resultant gradual reduction from year to year of salt concentration in drain water flowing through the Sunnyside line. Both in quantity and quality of salts in solution the average condition of exposure was slightly more serere at Sunnyside than at Fort Shaw. Relative severity was reflected in relative degree of disintegration recorded during 10 years of exposure. Not only were some of the leaner mixes of Group A but also some tile of Group B affected at the Sunnyside site. Specimens of Group C showed no

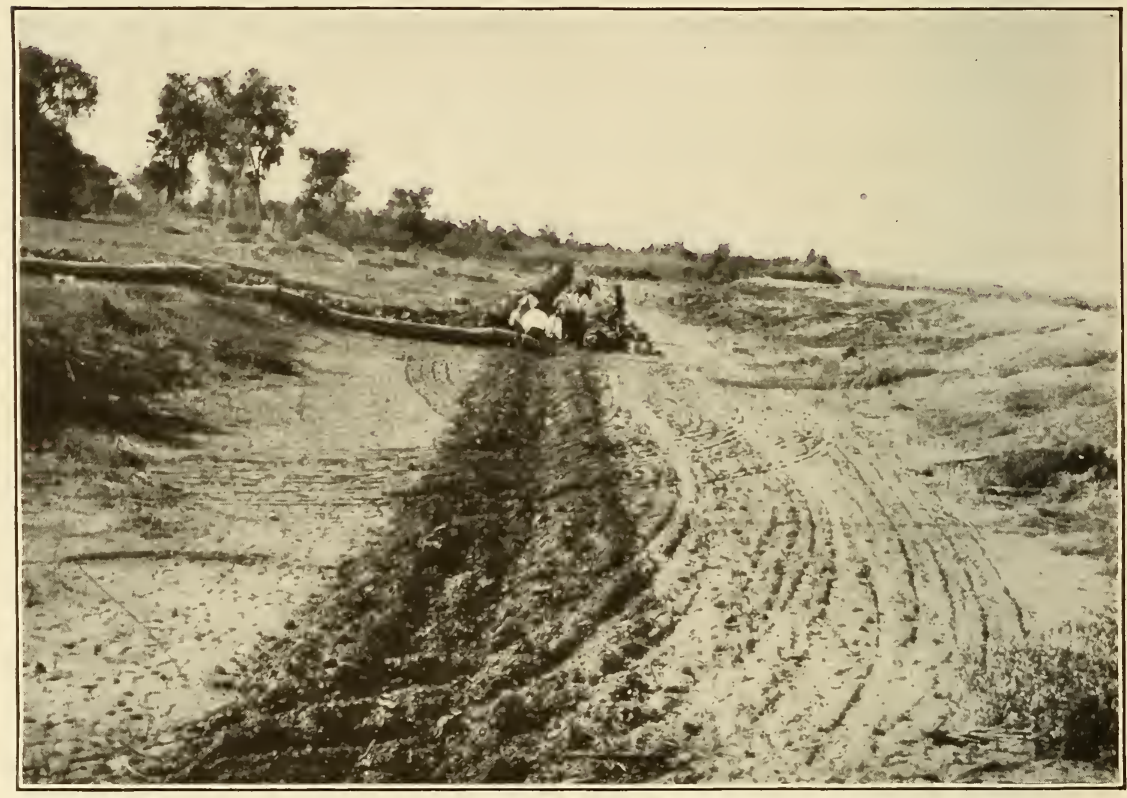

FIG. 9.-View from upper end of opened ditch for experimental drain at Y uma, Ariz., showing tile laid along the ditch ready for placing

deterioration during the 10 years, and only series 15 (sand-cement specimens) of Group D was affected, although the more permeable specimens of both groupings showed accumulations of salts within tile wall.

Yuma, Ariz.-The installation of a test drain line at Yuma was made in the line of an old slough where conditions were favorable for exposure in alkali water. Figure 10 shows the alkali water at the bottom of the trench, a condition continuing throughout the 10 years of exposure. Of all the alkali projects the Yuma site was the mildest in that the average concentration of salts in solution was the lowest. Though soluble sulphate salts were present, such salts did not predominate. During the 10 years of exposure to such condi- 
tions none of the types of tile under study indicated disintegration, though the more permeable specimens showed accumulations of salts within tile wall.

Roswell, N. Mex.-The site of the Roswell installation is shown in Figure 11. Ground water was encountered at the time of installation. Either due to deposition of silt in the experimental line or some other local cause the installation failed to carry off the ground water. The water table was so high at the termination of the tenth year

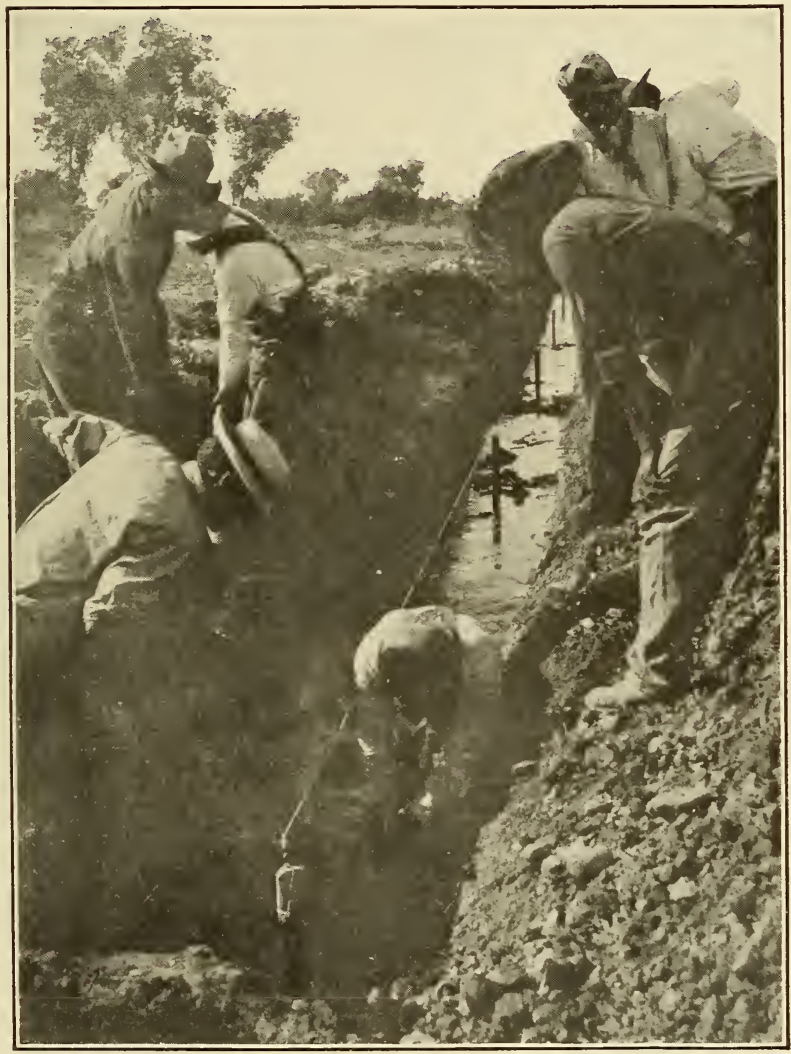

FIG. 10.-View of opened ditch at Yuma, Ariz., showing heavy flow of seepage water in the bottom; also the method of placing the tile

exposure period that it was not practicable to excavate a section for inspection. As in the case of the Yuma installation, the tile line at Roswell was subjected to submersion in alkaline water much of the time. The water in the drain line varied but little in salt concentration of a composition characterized as relatively mild in respect to soluble sulphate salts. At the termination of two years' exposure to such conditions series 17 , the richest of the handmade quaking con- 
sistency tile of Group C, evidenced surface disintegration (see fig. 12). This condition, later also appearing in series 18, was progressive. At the end of the sixth year of exposure only series 17 and 18 were visibly affected; the other specimens eridenced more or less accumulation of salts within tile walls in amounts apparently in proportion to relative permeability.

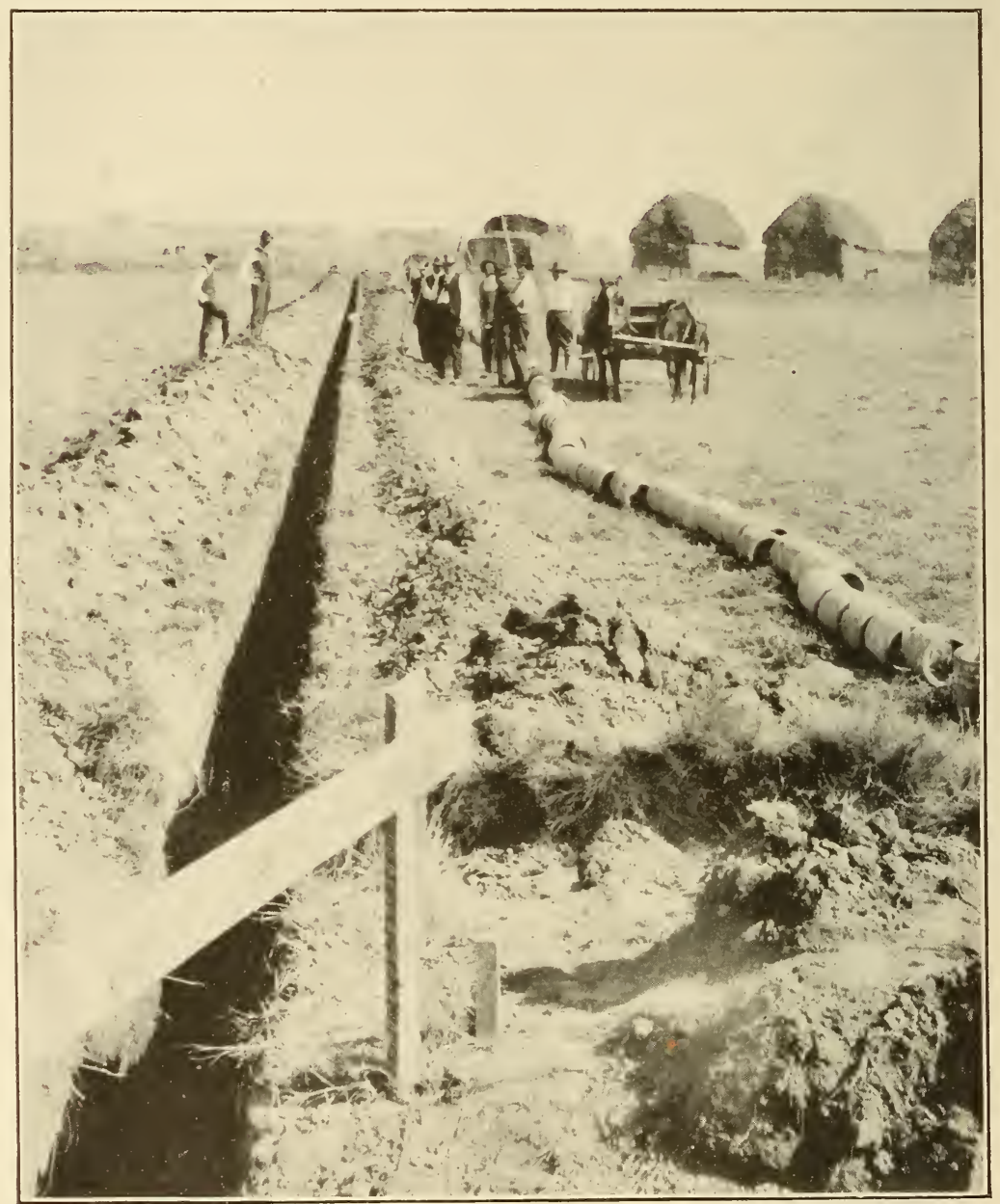

Fig. 11.- View from lower end of opened ditch for experimental drain at Roswell, N. Mex., showing tile strewn ready for placing. Note the entire trench is partly excavated and banks are vertical

Montrose, Colo.--In selecting the location for placing the tile near Montrose advantage was taken of a seepage flow created by leakage from the south canal of the United States Reclamation Service. In opening the trenclı both shale and adobe formations were encountered, with indications that most of the seepage occurred through the 

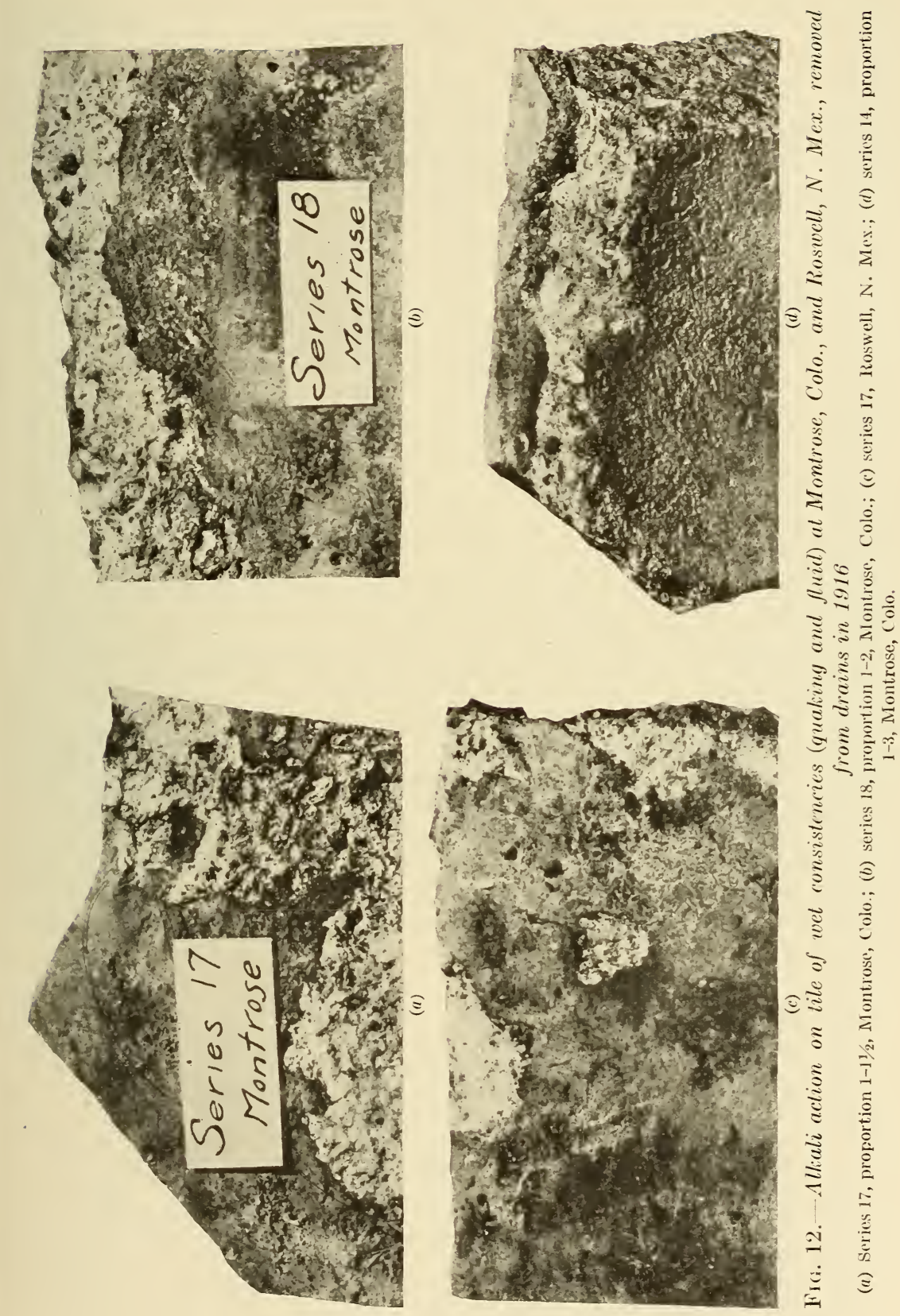

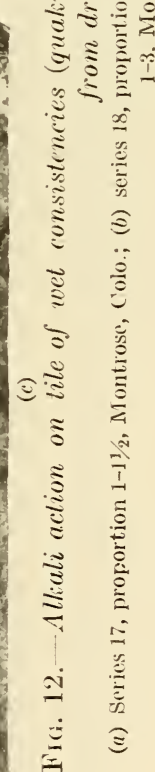


shale. Figure 13 shows a general view of this site while Figure 16 illustrates the alkali deposits probably originating from the seepage flow.

The concentration of dissolved alkali salts, characterized as the sulphate type, was relatively high throughout the 10 years of observation, with no direct evidence that the installation of a drain line was in this case an efficient local method for effecting a gradual reduction of alkali in the soil drained. The highest concentration of salts in drainage water recorded for this experimental line was found 9 years after the installation. A relatively high concentration of dissolved salts, maintained throughout the 10-year period, contributed to make the Montrose site one of serere exposure conditions.

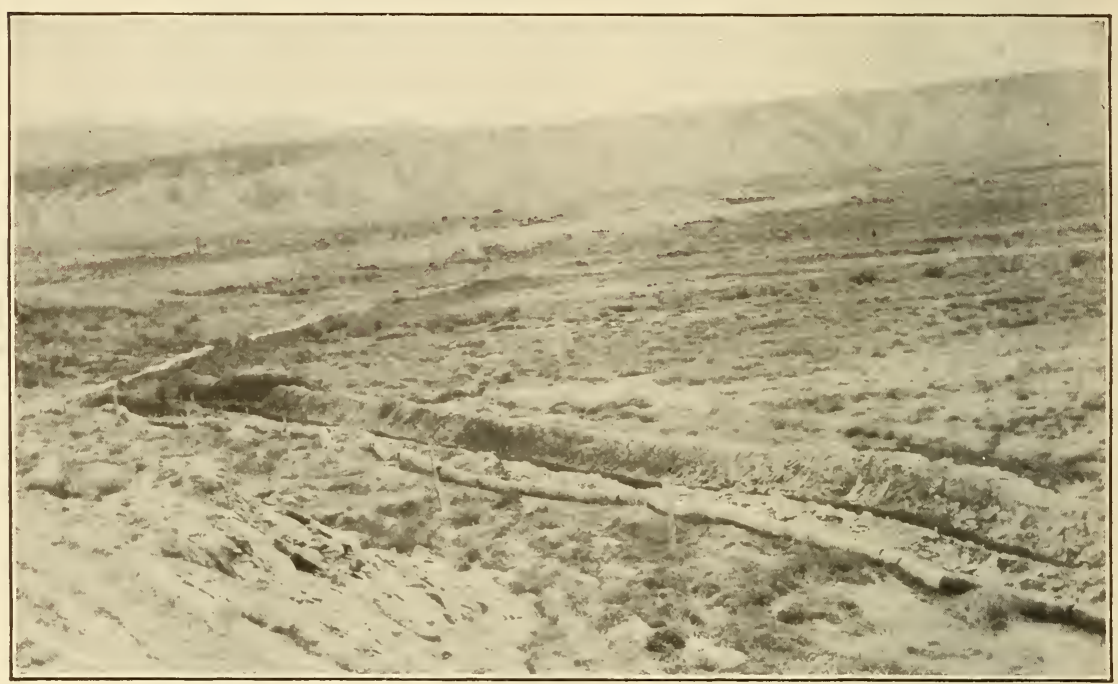

FIG. 13.- View from upper end of site of experimentai drain at Montrose, Colo. showing the opened ditch and the distribution of the tiles just previous to placing. Observe hard shale excavated at upper end to the right in picture

After three years of exposure, the tile of leanest proportions in Group A showed evidence of deterioration. As a unit, the tile of the same grouping proportioned 1:3 withstood the alkali environment, while some specimens of the richer mixtures showed disintegration at some period during the 10 years of exposure. As was demonstrated at some of the other alkali projects, the tile of Group B were little more durable than the leanest types of Group A. All tile series of Group C underwent some degree of disintegration during 10 years of exposure to the Montrose conditions. Series 15 (sandcement type) of Group D disintegrated during the first year of exposure while the corresponding series 14 (Portland cement type) of the same grouping first showed positive evidence of deterioration at the termination of the tenth year of exposure. 


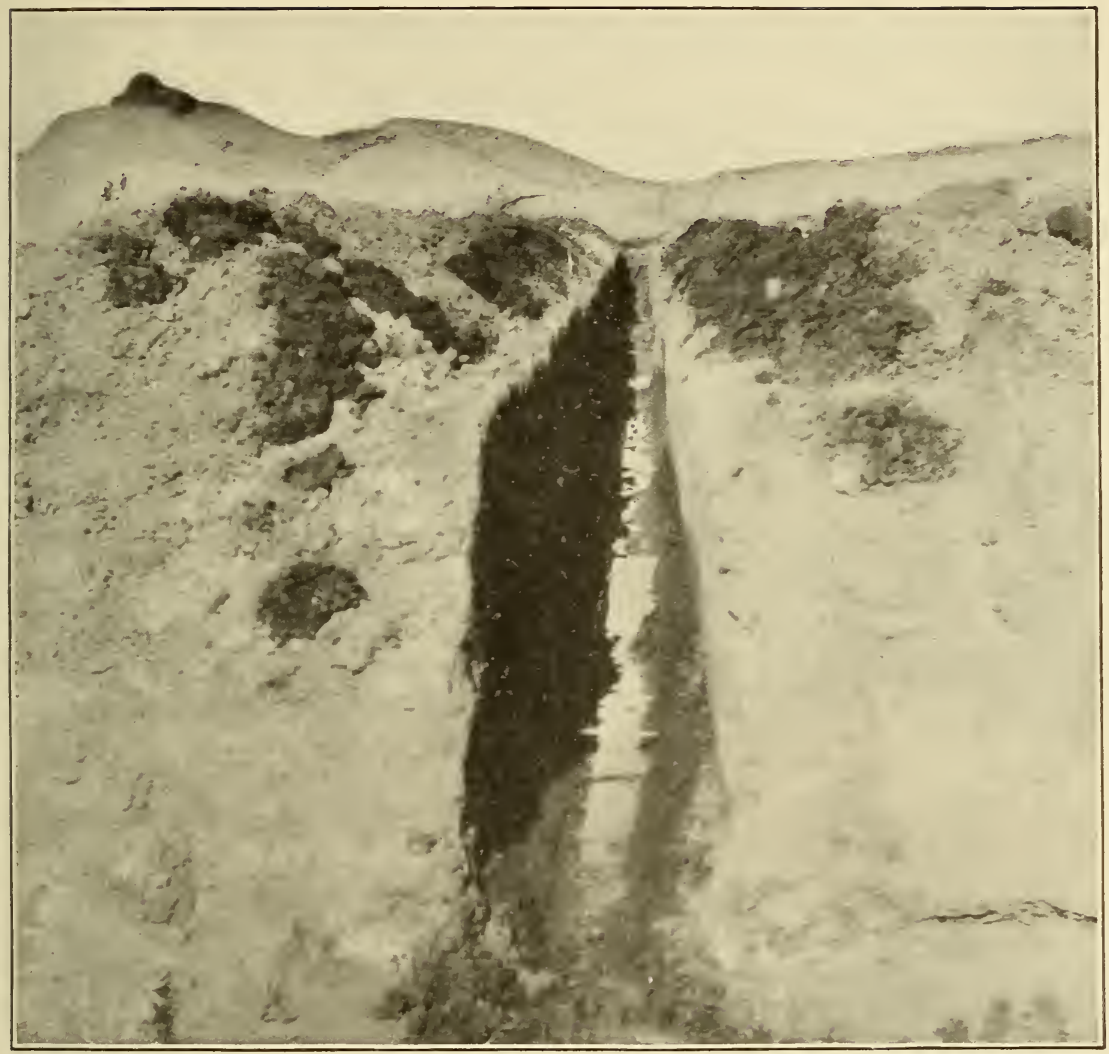

FIG. 14.-Lower end of opened ditch for experimental drain at Montrose, Colo., showing depth of completed trench, flow of seepage water, and alkali salts on surface of soil where partially dried in the foreground

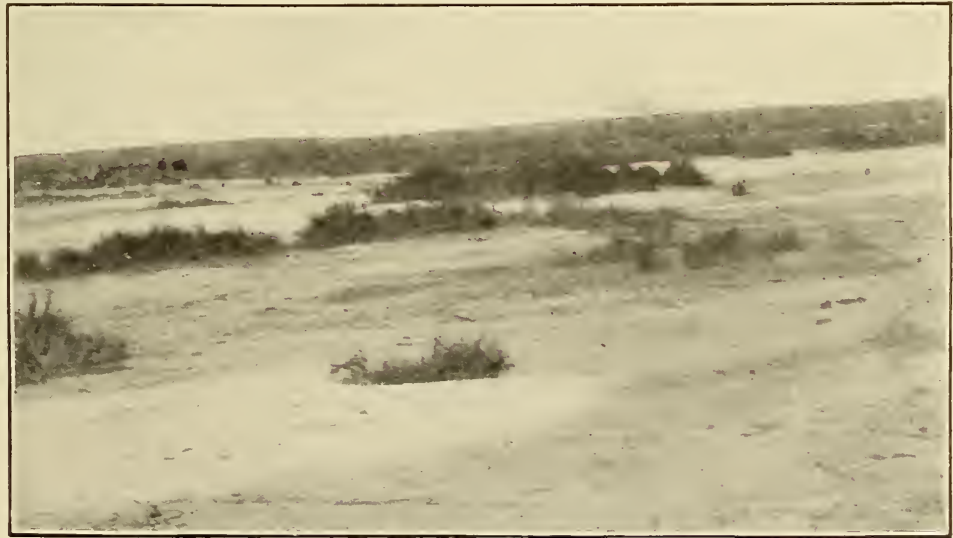

FIG. 15.-Tiew of site of experimental drain at Grand Junction, Colo., showing extremely heavy concentration of alkali salts on the surface of the ground. There is practically no vegetation other than alkali weed. Observe the salts are more concentrated on the high spots 
Grand Junction, Colo.-A 10-acre parcel of land near Grand Junction, known as the McKinney tract, previously irrigated and cultivated, was later abandoned agriculturally because of an accumulation of alkali on the surface and in the upper strata of the soil. The reclamation of the land of which this tract was a part was under-

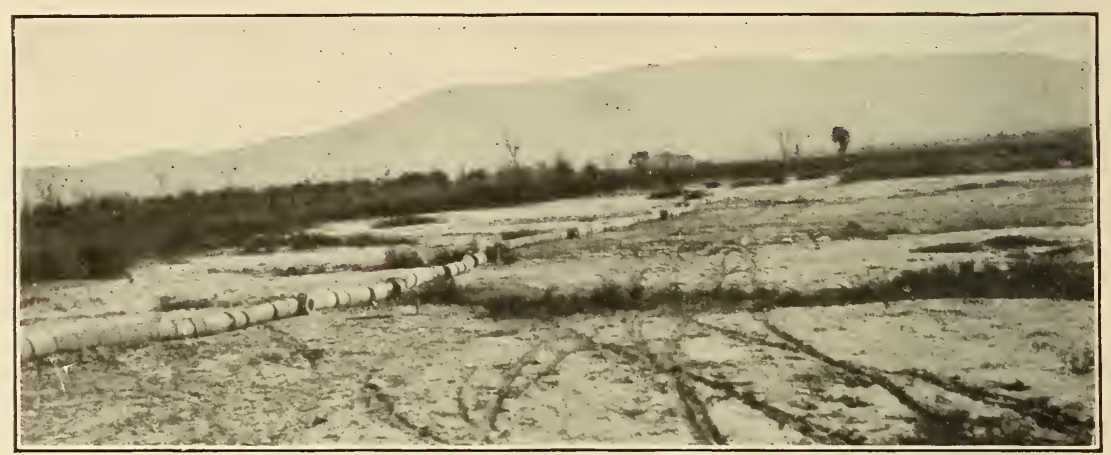

FIG. 16.- Site of experimental drain at Grand Junction, Colo., showing heavy alkali deposit. The tile have been strewn ready for placing. Note lack of vegetation

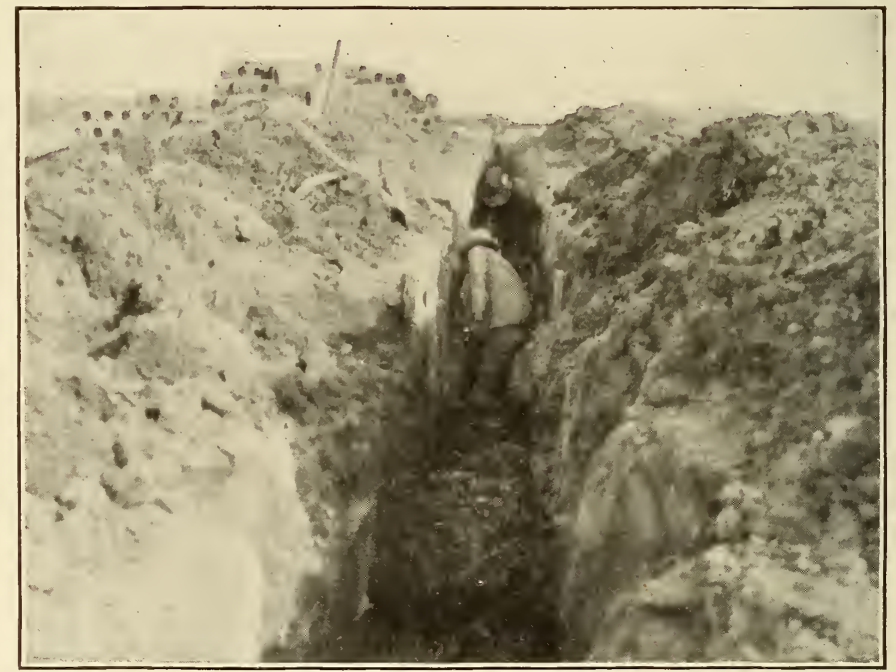

Frg. 17.-Opened ditch for experimental drain at Grand Junction, Colo., showing the difficulties encountered in placing the tile. Observe the caving banks and timber bracing required

taken under the supervision of Drainage Investigations, Department of Agriculture. 'The experimental drain placed in the McKinney tract by this bureau was tied in with other drainage systems installed as a part of the local reclamation project. Figures 15 and 16 illustrate the prevalence of surface alkali at time of the installation. 


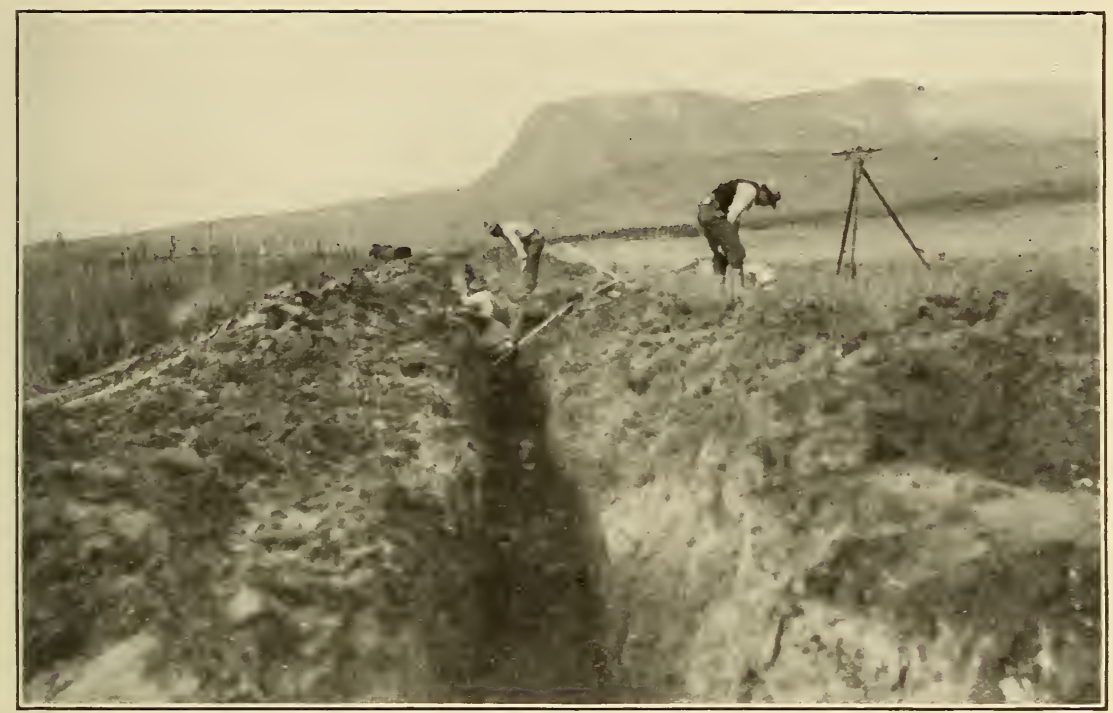

FiG. 18.-Opened ditch for experimental drain at Huntington, Utah, showing the character of the soil, lack of regetation due to alkali salts, and the approximate depth of excavation

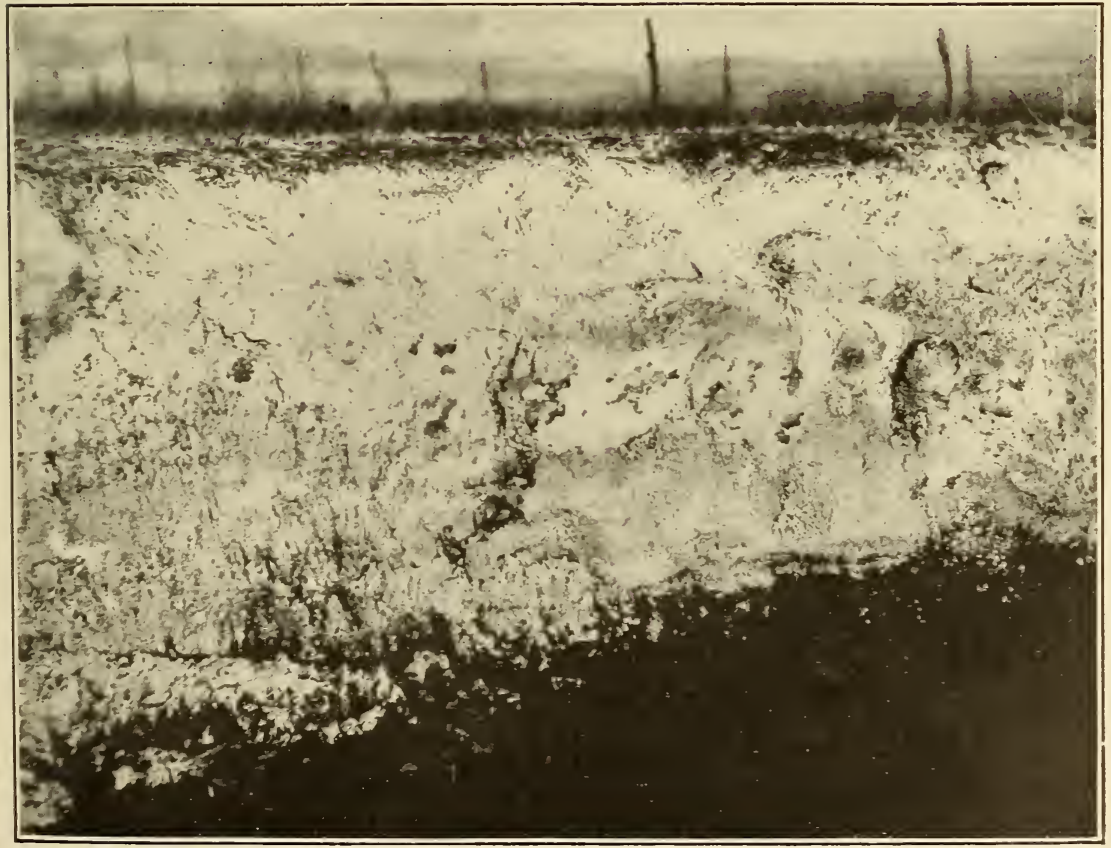

FIG. 19.- Bank of waste ditch, showing heavy white incrustation of alkali salts at Huntington, Utah

$56960^{\circ}-26 \dagger-4$ 
When the experimental drain was placed the lower portion of the trench was very wet and mucky. At the end of the tenth year comparatively dry conditions were encountered. Furthermore, there had been a gradual reduction of concentration of dissolved salts in the drainage water; that is, the efficacy of subdrainage as a method for lowering the water table and for incidentally gradually reducing the concentration of soluble salts in the soil was demonstrated.

This Grand Junction location, recognized at the time of drain installation as severe in point of alkali concentration and composition, gradually shaded off into a more and more mild exposure station as subdrainage gradually ameliorated the local alkali menace. Whatever disintegration was noted during the first six years of installation, therefore, made but little progress during the last four years of exposure.

Only the richest proportioned tile of Group A withstood the local environment over the 10-year period. All series of Group B underwent some degree of disintegration, again demonstrating that in spite of their relative richness these plastic consistency handmade tile have a relatively low resistance for concentrated alkaline waters. Only series 2 of Group C exhibited durability. Just as at the Montrose installation, both series of Group D underwent disintegration, but the decided superiority of the Portland cement type was again demonstrated.

Huntington, Utah.--The alkali district near Huntington was probably the product of heary irrigation without adequate subdrainage. Under such conditions alkali salts had accumulated to such an extent in upper soil strata as to make the particular location selected for the experimental drain probably the most severe to be found in the State. Figures 18 and 19 illustrate the prevailing conditions in the locality at time of experimental drain installation.

At some period between the third and sixth year exposure periods the tract involving the experimental drain was abandoned agriculturally. With irrigation discontinued the tract soon dried out to preclude further flow of water through the drain except, perhaps, during the winter months. A general absence of water tended to reduce materially the severity of alkali exposure conditions. Therefore the rate of disintegration of tile, if any, proceeded more rapidly during about the first five years of exposure or during only the periods when the soil was at least moistened.

All of the leaner mixes of Group A underwent more or less disintegration during the 10 years. The tile of Group B as a unit showed extensive disintegration except series 5, the tar-coated specimens; but the tar coating had been penetrated and the cement matrix of tile wall slightly affected. With the exception of series 18 , the tile of Group $\mathrm{C}$ were resistant to the environment during the 10 years of 
exposure. Both series of Group D were in the first stages of disintegration at the termination of the tenth year exposure period.

Crookston, Minn.-The installation of an experimental drain at the Northwest Agricultural School of the University of Minnesota

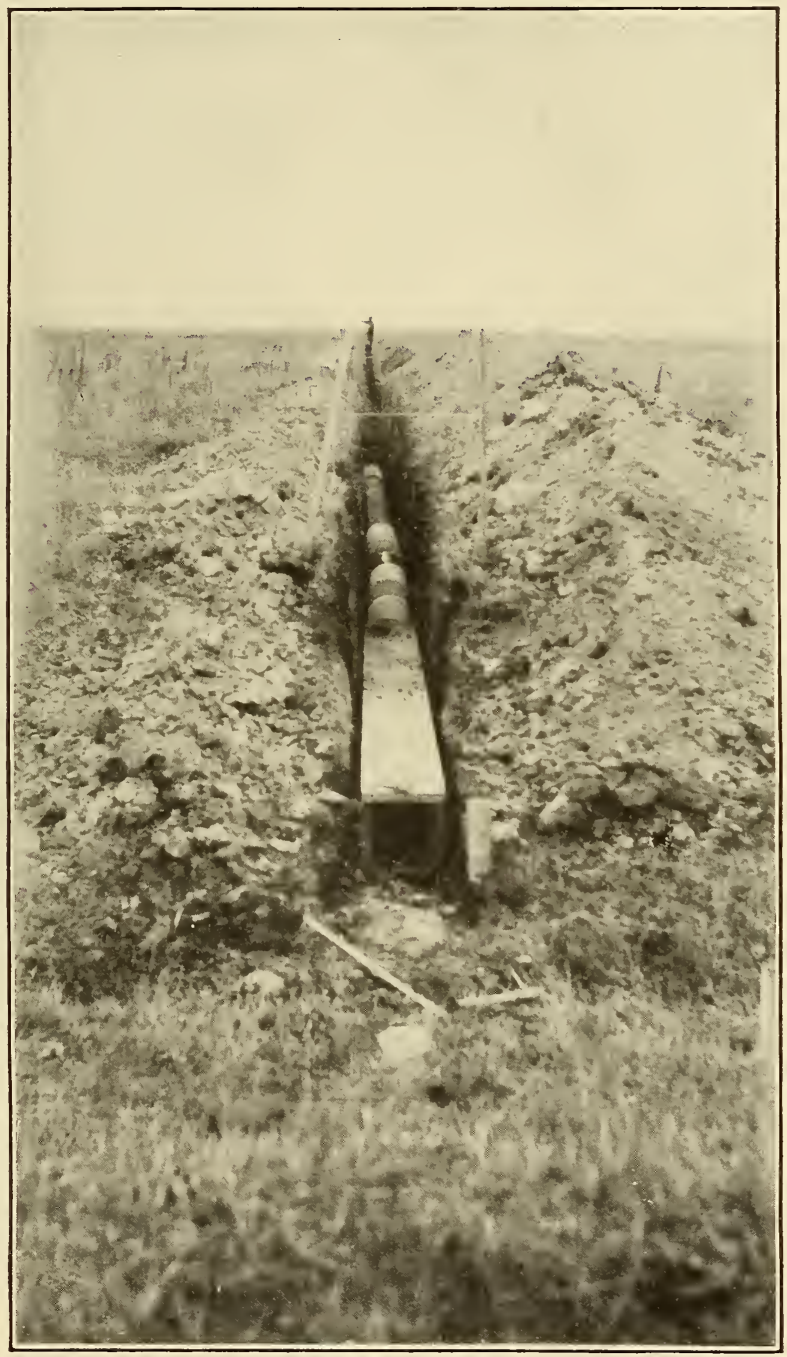

Fig. 20.-Lower end of experimental drain at Crookston, Minn., showing shallow installation of tile with box at outlet to prevent tile being washed out

was projected to corer field conditions embracing flat terrane lacking ready surface drainage and a ground water bearing only minute amounts of alkali. As is shown in Figure 20, the tile were placed in shallow installation, which circumstance may account for sereral 
specimens in a water-filled drain bursting under the freezing temperatures of the winter months.

Nothing has been found in the appearance of the tile exposed during a 10-year period to the fresh-water conditions at Crookston to indicate any harmful constituents in the soil or water.

Columbia, Mo.-On a tract of land under cultivation by the University of Missouri Agricultural School was selected a site offering a total fall of about 24 feet in the experimental drain projected for fresh-water installation. The drain line was placed to follow the

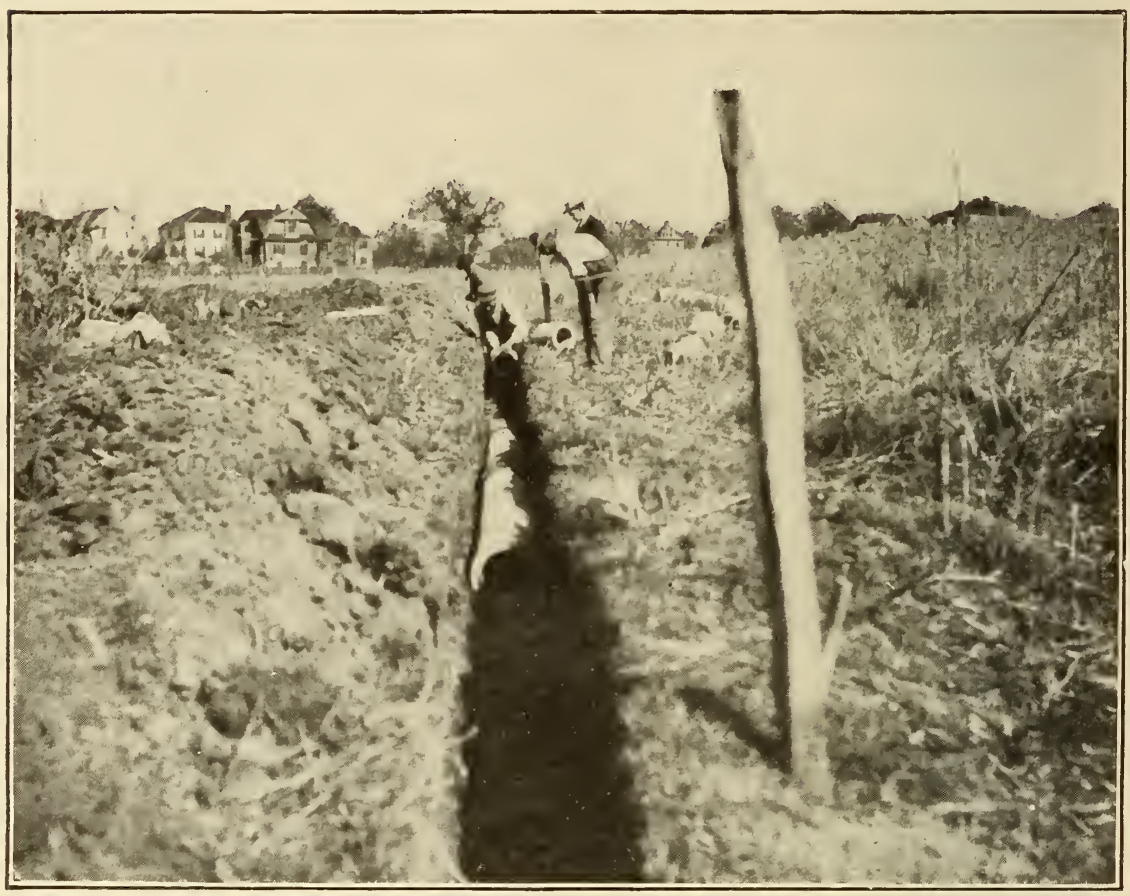

FIG. 21.-Lower end of experimental drain, Columbia, Mo., showing shallow installation of tile necessary on account of high outlet

line of a small channel which had been cut by surface water. The soil was moist, but no stream of water dereloped during the trenching. Figure 21 is a general view of the Columbia site.

At the termination of three years' exposure in fresh water conditions at Columbia some tile specimens showed evidence of disintegration on the lower, outer surface, indicated by the apparent dissolving away of cement to leave the sand grains coated with a brown stain. This action was in every case confined to the outer circumference in direct bearing on the bottom of the trench.

While the leaner mixtures of Group A were in some cases badly pitted, the richer and dense tile showed only slight surface action. 
(a)

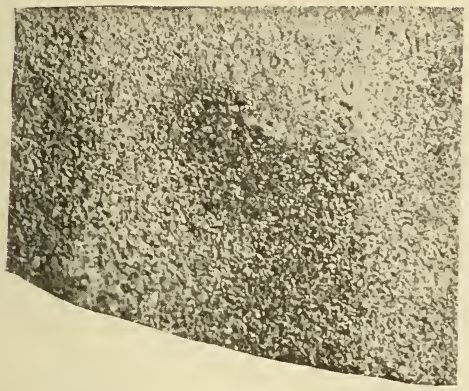

(c)

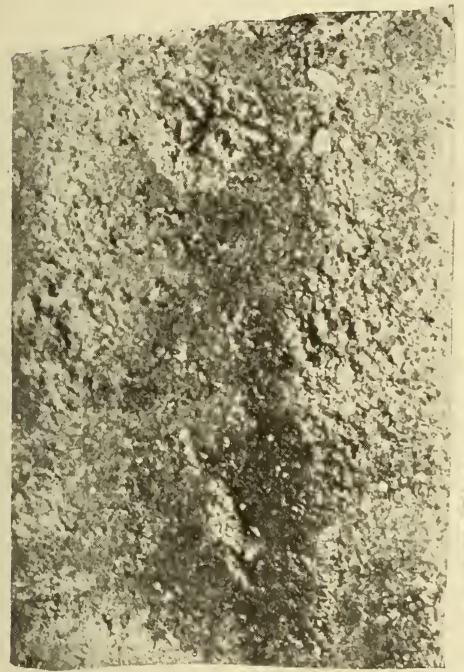

(b)
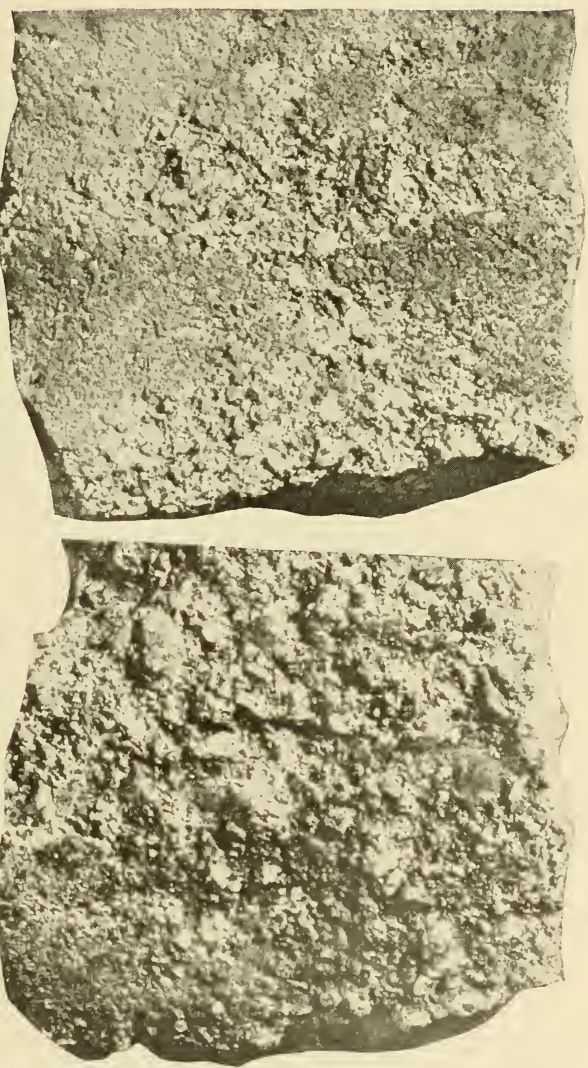

$(d)$

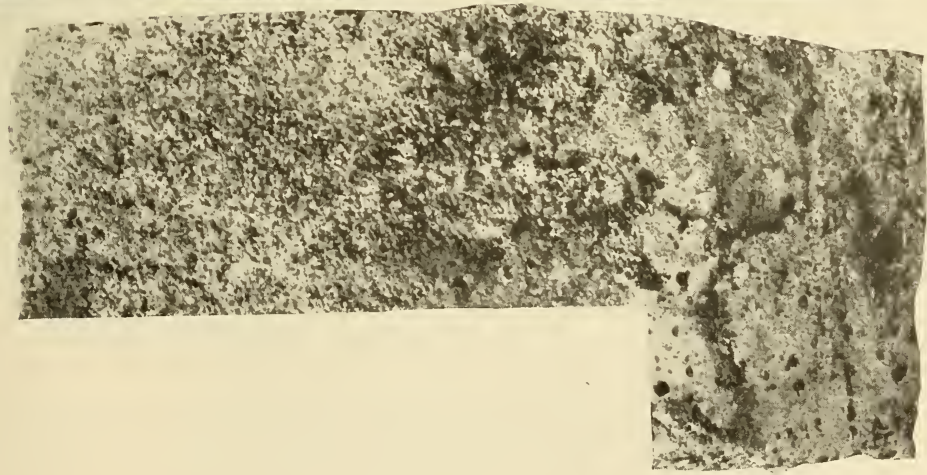

(e)

FIG. 22.-Surface disintegration of tile removed from drain at Columbia, Mo., in 1916 after three years' exposure

(a) Uninjured surface of a tile which has never been exposed in a drain; $(b)$ series 8, proportion 1-4, machinemade; (c) series 9, proportion 1-11/2, machinemade; $(d)$ series 8 ; $(e)$ series 2, proportions 1-21/2, quaking consistency, hand tamped. The lower right-hand surface is unaffected. 
Figure 22 illustrates typical cases. After six years of exposure the action was progressively worse, as illustrated in Figure 23. Tile series 3 of Group B was the most affected, while series 2 of Group C, representative of the best quality, was only slightly roughened.
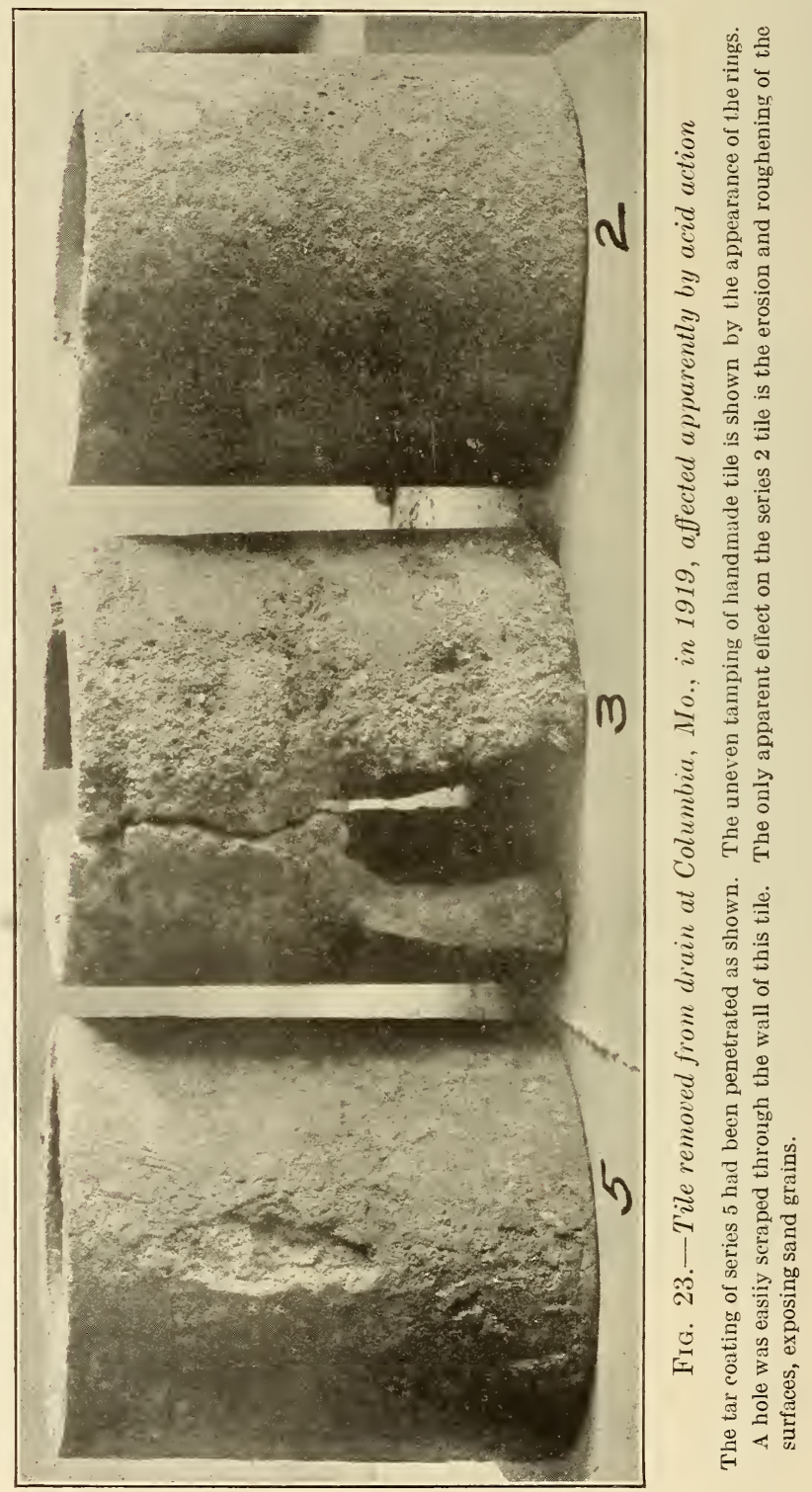

The tar coating of series 5 had been penetrated. Such surface pitting as was observed in certain specimens subjected to Columbia conditions is characteristically different from the evidences of alkali disintegration. Figure 24 illustrates the typical swelling and crack- 
ing characteristic in a tile deteriorated by alkali action. Tile excavated for observation at the termination of 10 years' exposure were taken from higher ground with less free soil water than previous

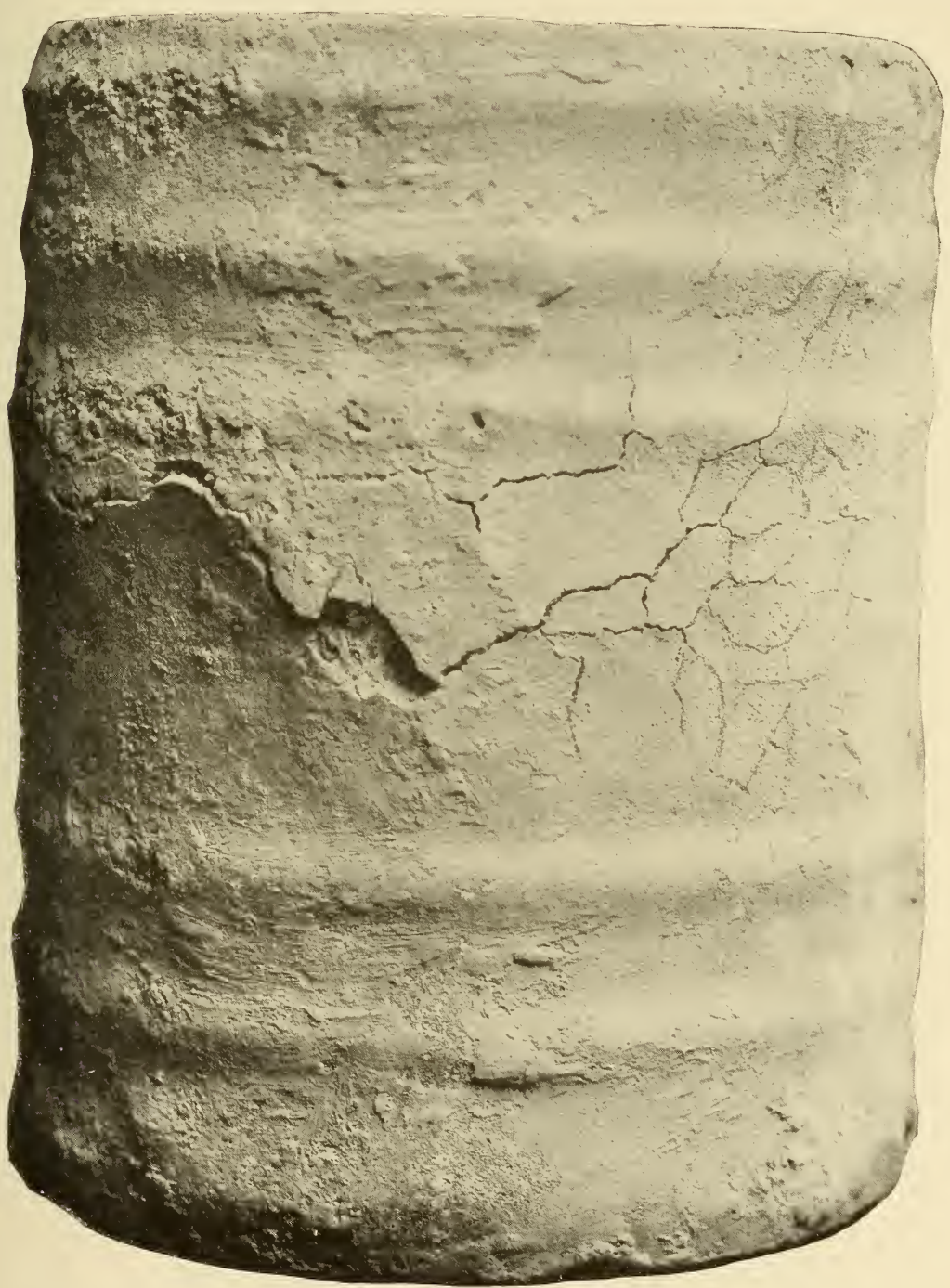

Fig. 24.--Swollen and cracked tile of series 16 after one year's exposure at Grand Junction, Colo. The interior surface is cracked similarly to the exterior

inspections embraced. This circumstance may explain why tile from the high ground were no further advanced in surface attack at the end of the tenth year than was observed in specimens after three years of contact with constantly wet soil. 
TABLE 6.-Individual results of crushing tests of experimental cement drain tile, 1923

[Total breaking load in pounds. See B. S. Tech. Papers Nos. 95 and 214 for previous tests. No inspection or test made at Poswell, N. Mex.!

\begin{tabular}{|c|c|c|c|c|c|c|c|c|c|c|}
\hline \multirow{3}{*}{$\begin{array}{c}\text { Series } \\
\text { number }\end{array}$} & \multicolumn{2}{|c|}{$\begin{array}{l}\text { Results after } \\
\text { exposure to fresh } \\
\text { water }\end{array}$} & \multicolumn{8}{|c|}{ Results after exposure to alkali water } \\
\hline & $\begin{array}{l}\text { Colum- } \\
\text { bia, } \\
\text { Mo. }{ }^{1}\end{array}$ & $\begin{array}{c}\text { Crooks- } \\
\text { ton, } \\
\text { Minn. }\end{array}$ & $\begin{array}{l}\text { Gar- } \\
\text { land, } \\
\text { Wyo. }\end{array}$ & $\begin{array}{l}\text { Fort } \\
\text { Shaw, } \\
\text { Mont. }\end{array}$ & $\begin{array}{l}\text { Sunny- } \\
\text { side, } \\
\text { Wash. }\end{array}$ & $\begin{array}{c}\text { Yuma, } \\
\text { Ariz. }\end{array}$ & $\begin{array}{l}\text { Mont- } \\
\text { rose, } \\
\text { Colo. }\end{array}$ & Grand $\mathrm{J}$ & $\begin{array}{l}\text { unction, } \\
\text { lo. }\end{array}$ & $\begin{array}{c}\text { Hunting- } \\
\text { ton, } \\
\text { Utah }\end{array}$ \\
\hline & Sec. 7 & Sec. 7 & Sec. 7 & Sec. 7 & Sec. 8 & Sec. 8 & Sec. 7 & Sec. 6 & Sec. 7 & Sec. 6 \\
\hline 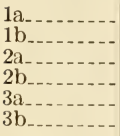 & $\begin{array}{l}2,800 \\
3,240 \\
2,630 \\
2,820 \\
2,120 \\
2,360\end{array}$ & $\begin{array}{l}(2) \\
(2) \\
3,010 \\
3,000 \\
3,320 \\
2,810\end{array}$ & $\begin{array}{l}33,460 \\
33,660 \\
73,290 \\
73,320 \\
33,560 \\
33,040\end{array}$ & $\begin{array}{l}43,760 \\
+3,350 \\
73,250 \\
73,420 \\
32,790 \\
32,250\end{array}$ & 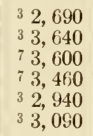 & $\begin{array}{l}33,180 \\
33,590 \\
73,230 \\
73,200 \\
33,380 \\
3 \\
3 \\
3\end{array}$ & $\begin{array}{r}52,210 \\
33,660 \\
73,750 \\
73,720 \\
32,840 \\
80\end{array}$ & & 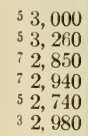 & $\begin{array}{l}\begin{array}{l}3 \\
2\end{array} 2,840 \\
52,400 \\
33,980 \\
33,360 \\
52,280 \\
52,680\end{array}$ \\
\hline $\begin{array}{l}4 \mathrm{a}_{2} \\
4 \mathrm{~b} \\
5 \mathrm{a} \\
5 \mathrm{~b} \\
6 \mathrm{a} \\
6 \mathrm{~b}\end{array}$ & $\begin{array}{l}2,830 \\
2,820 \\
2,580 \\
2,920 \\
2,070 \\
2,320\end{array}$ & $\begin{array}{l}2,200 \\
2,810 \\
1,810 \\
2,920 \\
2,820 \\
3,700\end{array}$ & $\begin{array}{r}32,900 \\
32,530 \\
+2,470 \\
(6) \\
32,780 \\
33,170\end{array}$ & $\begin{array}{r}+2,770 \\
+2,720 \\
+3,550 \\
+2,970 \\
3 \\
3,190 \\
3 \\
3,330\end{array}$ & $\begin{array}{r}+3,380 \\
+3,990 \\
32,970 \\
3 \\
3 \\
+3,710 \\
+2,690 \\
+2,670\end{array}$ & 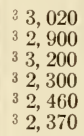 & $\begin{array}{r}5,550 \\
+3,980 \\
32,970 \\
32,390 \\
33,550 \\
80\end{array}$ & & $\begin{array}{r}52,720 \\
52,900 \\
80 \\
80 \\
80 \\
80 \\
80\end{array}$ & $\begin{array}{r}3,280 \\
73,390 \\
32,850 \\
33,380 \\
32,690 \\
32,350\end{array}$ \\
\hline $\begin{array}{l}7 \mathrm{a} \ldots \ldots \\
7 \mathrm{~b} \ldots \ldots \\
8 \mathrm{a} \ldots . . \\
8 \mathrm{~b}_{\ldots-\ldots} \\
9 \mathrm{a}_{\ldots-\ldots} \\
9 \mathrm{~b}_{\ldots-\ldots}\end{array}$ & $\begin{array}{r}1,320 \\
1,130 \\
820 \\
850 \\
1,300 \\
1,290\end{array}$ & $\begin{array}{l}1,080 \\
1,120 \\
(2) \\
(2) \\
(2) \\
1,570\end{array}$ & $\begin{array}{r}+1,130 \\
71,390 \\
3810 \\
3960 \\
+1,340 \\
71,450\end{array}$ & $\begin{array}{c}+1,380 \\
(6) \\
31,080 \\
31,250 \\
41,250 \\
+1,250\end{array}$ & $\begin{array}{r}+1,510 \\
+1,180 \\
+1,040 \\
4950 \\
71,620 \\
+1,970\end{array}$ & $\begin{array}{ll}7 & 1,460 \\
7 & 1,500 \\
3 & 1,150 \\
3 & 1,060 \\
7 & 1,950 \\
7 & 1,620\end{array}$ & $\begin{array}{r}31,320 \\
+1,570 \\
3970 \\
3930 \\
41,720 \\
+1,230\end{array}$ & $\begin{array}{l}+1,400 \\
+1,490 \\
31,050 \\
31,010 \\
+1,450 \\
+1,370\end{array}$ & & $\begin{array}{l}71,500 \\
71,300 \\
31,100 \\
31,050 \\
+1,670 \\
+1,760\end{array}$ \\
\hline $\begin{array}{l}10 \mathrm{a} \ldots \ldots \\
10 \mathrm{~b} \ldots \ldots \\
11 \mathrm{a} \ldots \ldots \\
12 \mathrm{~b} \ldots \ldots \\
12 \mathrm{~b} \ldots \ldots\end{array}$ & $\begin{array}{r}1,410 \\
1,420 \\
1,160 \\
720 \\
720 \\
800\end{array}$ & $\begin{array}{l}1,580 \\
1,690 \\
1,290 \\
1,480 \\
1,240 \\
1,070\end{array}$ & $\begin{array}{rr}3 & 1,000 \\
7 & 1,050 \\
7 & 1,200 \\
7 & 1,230 \\
3 & 690 \\
& 3830\end{array}$ & $\begin{array}{r}41,670 \\
+1,540 \\
+1,360 \\
+1,500 \\
31,030 \\
+3940\end{array}$ & $\begin{array}{l}+1,380 \\
+1,640 \\
+1,190 \\
+1,240 \\
+1,080 \\
+1,310\end{array}$ & $\begin{array}{ll}7 & 1,730 \\
7 & 1,490 \\
3 & 1,430 \\
3 & 1,530 \\
3 & 1,310 \\
3 & 1,290\end{array}$ & $\begin{array}{r}41,850 \\
31,330 \\
+1,430 \\
+1,660 \\
51,110 \\
5860\end{array}$ & $\begin{array}{l}41,640 \\
41,640 \\
+1,500 \\
51,050 \\
31,140 \\
+1,100\end{array}$ & & $\begin{array}{l}+1,830 \\
+1,610 \\
51,490 \\
51,230 \\
51,070 \\
31,100\end{array}$ \\
\hline $\begin{array}{l}13 \mathrm{a} \ldots \ldots \\
13 \mathrm{~b} \ldots \\
14 \mathrm{a}_{1} \ldots \ldots \\
14 \mathrm{~b} \ldots \ldots \\
15 \mathrm{~b} \ldots \ldots\end{array}$ & $\begin{array}{l}1,300 \\
1,240 \\
2,400 \\
2,320 \\
1,570 \\
1,580\end{array}$ & $\begin{array}{l}1,390 \\
1,300 \\
3,220 \\
2,860 \\
1,630 \\
1,620\end{array}$ & $\begin{array}{l}71,360 \\
71,470 \\
42,730 \\
72,840 \\
71,830 \\
+1,670\end{array}$ & $\begin{array}{r}5760 \\
+1,580 \\
73,070 \\
73,020 \\
+1,620 \\
+2,150\end{array}$ & $\begin{array}{l}71,860 \\
+1,500 \\
73,230 \\
73,000 \\
+2,160 \\
+2,000\end{array}$ & $\begin{array}{l}71,780 \\
72,000 \\
72,930 \\
73,040 \\
42,050 \\
+1,370\end{array}$ & $\begin{array}{r}+1,630 \\
41,310 \\
73,530 \\
53,530 \\
80 \\
80\end{array}$ & $\begin{array}{l}31,150 \\
31,330 \\
51,850 \\
3 \\
2,520 \\
3 \\
2,950 \\
3 \\
1,750\end{array}$ & $\begin{array}{r}2,720 \\
2,630 \\
80 \\
80\end{array}$ & $\begin{array}{r}+1,480 \\
+2,090 \\
+2,740 \\
52,280 \\
80 \\
50\end{array}$ \\
\hline $\begin{array}{l}16 \mathrm{a}_{1} \\
16 \mathrm{~b} \\
17 \mathrm{a} \\
17 \mathrm{~b} \ldots \\
18 \mathrm{a} \\
18 \mathrm{~b}\end{array}$ & $\begin{array}{l}630 \\
660 \\
(6) \\
\left.{ }^{6}\right) \\
1,23 C \\
1,380\end{array}$ & $\begin{array}{l}1,070 \\
1,110 \\
(2) \\
(2) \\
(2) \\
(2)\end{array}$ & $\begin{array}{l}{ }^{8} 0 \\
{ }^{8} 0 \\
(6) \\
(6) \\
(6) \\
(6)\end{array}$ & $\begin{array}{rl} & 3980 \\
& 5680 \\
7 & 1,620 \\
& (6) \\
7 & 1,780 \\
& (6)\end{array}$ & $\begin{array}{c}+1,200 \\
+1,210 \\
71,770 \\
(6) \\
71,330 \\
\quad(6)\end{array}$ & $\begin{array}{cc}3 & 1.250 \\
3 & 1,260 \\
7 & 1,320 \\
& (6) \\
7 & 1,570 \\
& (6)\end{array}$ & $\begin{array}{r}5800 \\
80 \\
80 \\
\left.{ }^{5}{ }^{6}\right) \\
80 \\
80 \\
80\end{array}$ & $\begin{array}{r}51,200 \\
80\end{array}$ & $\begin{array}{l}+1,530 \\
51,530 \\
51,700 \\
(6)\end{array}$ & $\begin{array}{r}3.010 \\
5880 \\
72,000 \\
71,430 \\
72,000 \\
51,470\end{array}$ \\
\hline $\begin{array}{l}19 a_{\ldots} \ldots \ldots \\
19 b_{\ldots} \ldots \ldots \\
20 a_{\ldots} \ldots \\
20 b_{\ldots} \ldots \ldots \\
21 \mathrm{~b}_{\ldots} \ldots \ldots\end{array}$ & $\begin{array}{r}1,450 \\
1,660 \\
1,430 \\
1,350 \\
970 \\
1,120\end{array}$ & $\begin{array}{l}1,650 \\
(6) \\
1,870 \\
(6) \\
1,190 \\
1,220\end{array}$ & $\begin{array}{cl} & (6) \\
& (6) \\
& (6) \\
& (6) \\
4 & 1,210 \\
4 & 1,080\end{array}$ & $\begin{array}{ll}7 & 1,850 \\
7 & 2,000 \\
7 & 1,770 \\
7 & 1,970 \\
3 & 1,180 \\
3 & 1,210\end{array}$ & $\begin{array}{l}71,590 \\
71,560 \\
71,650 \\
71,510 \\
41,270 \\
+1,350\end{array}$ & $\begin{array}{l}71,780 \\
71,730 \\
71,770 \\
71,680 \\
41,410 \\
41,460\end{array}$ & $\begin{array}{cc}7 & 2,150 \\
7 & 2,190 \\
7 & 1,930 \\
& (6) \\
& 5910 \\
5 & 1,050\end{array}$ & & $\begin{array}{c}31,680 \\
72,000 \\
71,770 \\
\quad(6) \\
5860 \\
51,220\end{array}$ & $\begin{array}{r}\vdots 1,670 \\
: 1,750 \\
i 2,050 \\
(6) \\
i 1,450 \\
; 1,500\end{array}$ \\
\hline
\end{tabular}

1 Disintegration in evidence on all tile series 1 to 20 . See p. 62, B. S. Tech. Paper No. 95.

2 Cracked longitudinally, apparently by freezing of water in drain while full.

3 Saturated with water; much alkali apparent on fractured surfaces. No cracking, swelling, or disin-

tegration apparent.
4 Saturated with water; traces of alkali apparent on fractured surfaces. No cracking, swelling, or disintegration apparent.

5 Saturated with water; copious alkali in tile wall attended with disintegration.

${ }_{7}^{6}$ Mo inspection or test made. apparent.

Swollen, cracked, broken in removal from drain, considered as " $O$ "' in strength averages. 
TABLE 7.-Average results of crushing tests of experimental cement drain tile

[Results in 1914 are generally average of 2 tests, in 1916 average of 4 tests, in 1919 average of 4 tests, and in 1923 average of 2 tests]

EXPOSED TO FRESH WATER

\begin{tabular}{|c|c|c|c|c|c|c|c|c|c|c|c|c|c|c|c|}
\hline $\begin{array}{l}\text { Proportion } \\
\text { Consistency } \\
\text { Method of molding. } \\
\text { Wall thickness } \\
\text { Special treatment }\end{array}$ & \multicolumn{5}{|c|}{$\begin{array}{c}1 \text { to } 21 / 2 \\
\text { Plastic } \\
\text { Hand tamped } \\
11 / 2 \text { inches }\end{array}$} & \multicolumn{5}{|c|}{$\begin{array}{c}1 \text { to } 21 / 2 \\
\text { Quaking } \\
\text { Hand tamped } \\
11 / 2 \text { inches }\end{array}$} & \multicolumn{5}{|c|}{$\begin{array}{c}1 \text { to } 2 \\
\text { Plastic } \\
\text { Hand tamped } \\
11 / 2 \text { inches }\end{array}$} \\
\hline Series number...... & \multicolumn{5}{|c|}{1} & \multicolumn{5}{|c|}{2} & \multicolumn{5}{|c|}{3} \\
\hline Year of tests_...... & 1914 & 1915 & 1916 & 1919 & 1923 & 1914 & 1915 & 1916 & 1919 & 1923 & 1914 & 1915 & 1916 & 1919 & 1923 \\
\hline $\begin{array}{l}\text { Columbia, Mo } \\
\text { Crookston, Minn }\end{array}$ & $\begin{array}{l}2,680 \\
2,670\end{array}$ & $\begin{array}{l}2,890 \\
3,250\end{array}$ & $\begin{array}{l}2,680 \\
3,380\end{array}$ & $\begin{array}{l}2,260 \\
3,260\end{array}$ & $\begin{array}{l}3,020 \\
(1)\end{array}$ & $\begin{array}{l}2,490 \\
2,915\end{array}$ & $\begin{array}{l}3,175 \\
3,125\end{array}$ & $\begin{array}{l}2,600 \\
3,340\end{array}$ & $\begin{array}{l}2,380 \\
3,250\end{array}$ & $\begin{array}{l}2,725 \\
3,005\end{array}$ & $\begin{array}{l}2,585 \\
3,000\end{array}$ & $\begin{array}{l}3,505 \\
3,100\end{array}$ & $\begin{array}{l}2,350 \\
3,300\end{array}$ & $\begin{array}{l}2,685 \\
3,015\end{array}$ & $\begin{array}{l}2,240 \\
3,065\end{array}$ \\
\hline $\begin{array}{l}\text { Grand average } \\
\text { Maximum individual } \\
\text { Minimum individual }\end{array}$ & $\begin{array}{l}2,680 \\
2,760 \\
2,580\end{array}$ & $\begin{array}{l}3,070 \\
3,600 \\
2,740\end{array}$ & $\begin{array}{l}3,030 \\
3,570 \\
2,615\end{array}$ & $\begin{array}{l}2,760 \\
3,590 \\
1,770\end{array}$ & $\begin{array}{l}3,020 \\
3,240 \\
2,800\end{array}$ & $\begin{array}{l}2,705 \\
3,085 \\
2,385\end{array}$ & $\begin{array}{l}3,150 \\
3,340 \\
2,910\end{array}$ & $\begin{array}{l}2,970 \\
3,600 \\
2,445\end{array}$ & $\begin{array}{l}2,815 \\
3,550 \\
2,330\end{array}$ & $\begin{array}{l}2,865 \\
3,010 \\
2,630\end{array}$ & $\begin{array}{l}2,790 \\
3,230 \\
2,480\end{array}$ & $\begin{array}{l}3,305 \\
3,550 \\
3,100\end{array}$ & $\left\{\begin{array}{l}2,825 \\
3,450 \\
1,995\end{array}\right.$ & $\begin{array}{l}52,850 \\
3,190 \\
2,280\end{array}$ & $\left\{\begin{array}{l}2,655 \\
3,320 \\
2,120\end{array}\right.$ \\
\hline
\end{tabular}

\section{EXPOSED TO ALKALI WATER}

Garland, Wyo.

Fort Shaw, Mont

Sunnyside, Wash

Yuma, Ariz

roma, Ariz........

Roswell, N. Mex

Grand Junction, Colo

Huntington, Utah....

Grand average

Tasimum individul Minimum individual 2, $1051,960 \quad 0 \quad 02,2102,4902,5352,7153,0902,8501,375^{1} 1,585 \quad 0 \quad 0 \quad 0$

$3,2802,3902,9303,1203,5602,9552,7603,0653,2403,3052,6551,6402,4002,5803,300$ , (1) , $5002,52,652,7353,1653,1452,9053,2753,4203,5302,2752,8702,5402,6003,01$ , , $7152,6352,7802,825$ (1) $3,1403,0103,3503,430$ (1) 2, $6652,3553,0802,935$ ( , 795 3, 005 2, $9153,4702,935$ 3, $0503,2053,2853,9753,7352,2802,2951,7701,8781,420$ , $6302,6651,7501,1703,1302,8953,4453,2753,4702,8952,1301,2851,6659252,860$ $2,2702,8053,3402,5152,6203,4553,3253,5103,4003,6701,6752,4352,3602,2152,480$

$2,7352,7152,7502,7503,1903,0203,0303,2803,4253,3852,3152,3202,3452,2552,650$

$4203,0803,8503,8303,7603,5903,5003,9504,0003,9803,3653,7603,4503,0803,560$

' No test.

EXPOSED TO FRESH WATER

\begin{tabular}{|c|c|c|c|c|c|c|c|c|c|c|c|c|c|c|c|}
\hline $\begin{array}{l}\text { Proportion } \\
\text { Consistency } \\
\text { Method of molding } \\
\text { Wall thickness... } \\
\text { Special treatment }\end{array}$ & \multicolumn{5}{|c|}{$\begin{array}{c}1 \text { to } 2 \\
\text { Plastic } \\
\text { Hand tamped } \\
11 / 2 \text { inches } \\
\text { Dipped in cement grout }\end{array}$} & \multicolumn{5}{|c|}{$\begin{array}{c}1 \text { to } 2 \\
\text { Plastic } \\
\text { Hand tamped } \\
11 / 2 \text { inches } \\
\text { Dipped in tar }\end{array}$} & \multicolumn{5}{|c|}{$\begin{array}{c}1 \text { to } 2 \\
\text { Plastic } \\
\text { Hand tamped } \\
11 / 2 \text { inches } \\
10 \text { per cent ferrous sulphate }\end{array}$} \\
\hline Series number.... & \multicolumn{5}{|c|}{4} & \multicolumn{5}{|c|}{5} & \multicolumn{5}{|c|}{6} \\
\hline Year of tests... & 1914 & 1915 & 1916 & 1919 & 1923 & 1914 & 1915 & 1916 & 1919 & 1923 & 1914 & 1915 & 1916 & 1919 & 1923 \\
\hline $\begin{array}{l}\text { Columbia, Mo } \\
\text { Crookston, Minn }\end{array}$ & $\begin{array}{l}2,670 \\
2,670\end{array}$ & $\begin{array}{l}2,785 \\
2,635\end{array}$ & $\begin{array}{l}2,520 \\
3,095\end{array}$ & $\begin{array}{l}2,370 \\
2,690\end{array}$ & $\begin{array}{l}2,825 \\
2,505\end{array}$ & $\begin{array}{l}2,345 \\
2,385\end{array}$ & $\begin{array}{l}2,760 \\
2,585\end{array}$ & $\begin{array}{l}2,670 \\
2,680\end{array}$ & 2,140 & $\begin{array}{l}2,750 \\
2,365\end{array}$ & $\begin{array}{l}2,640 \\
2,705\end{array}$ & $\begin{array}{l}2,265 \\
3,050\end{array}$ & $\begin{array}{l}2,330 \\
3,210\end{array}$ & 2,200 & $\begin{array}{l}2,195 \\
3,260\end{array}$ \\
\hline $\begin{array}{l}\text { Grand average } \\
\text { Masimum individual } \\
\text { Minimum individual }\end{array}$ & $\begin{array}{l}2,670 \\
2,950 \\
2,395\end{array}$ & $\begin{array}{l}2,710 \\
3,340 \\
2,230\end{array}$ & $\begin{array}{l}2,810 \\
2,480 \\
2,415\end{array}$ & $\begin{array}{l}2,530 \\
2,910 \\
1,990\end{array}$ & $\begin{array}{l}2,665 \\
2,830 \\
2,200\end{array}$ & & $\begin{array}{l}2,675 \\
3,080 \\
2,440\end{array}$ & $\begin{array}{l}2,675 \\
2,890 \\
2,415\end{array}$ & 52,335 & 2,560 & $\begin{array}{l}2,675 \\
2,885 \\
2,525\end{array}$ & $\begin{array}{l}2,660 \\
3,340 \\
2,140\end{array}$ & 2,770 & $\begin{array}{l}2,37 \\
2,70 \\
1,90\end{array}$ & $\begin{array}{l}2,730 \\
3,700\end{array}$ \\
\hline
\end{tabular}

EXPOSED TO ILKALI WATER

Garland, W vo

Fort Shaw, Mont

Surnyside, Wash $2,715|2,470| 2,460|2,700| 2,7152,695|2,355| 2,280|2,740| 2,470|2,125| 2,360|2,570| 2,2352,975$ $2,0852,3802,4502,710|2,7452,500| 2,8052,5302,6653,2802,630 \mid 2,2902,1252,3403,260$

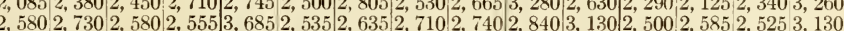

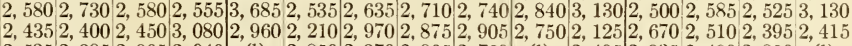
$2,5352,3952,9052,940$ (1) $2,8502,3702,9052,760$ (1) $2,495 \mid 2,3: 352,4902,800$ (1)

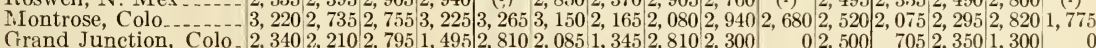

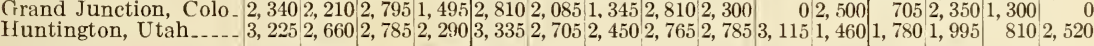

Tu Maximum individual $3,2303,0703,3353,450,3,9903,2303,0003,5003,3203,5902,9852,9203,5303,1503,590$

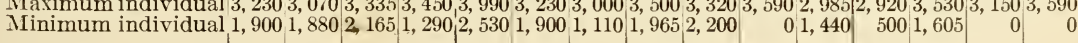

1 No test. 
TABLE 7.-Average results of crushing tests of experimental cement drain tile-Con. EXPOSED TO FRESH WATER

\begin{tabular}{|c|c|c|c|c|c|c|c|c|c|c|c|c|c|c|c|}
\hline $\begin{array}{l}\text { Proportion } \\
\text { Consistency } \\
\text { Method of molding.- } \\
\text { Wall thickness } \\
\text { Special treatment..... }\end{array}$ & \multicolumn{5}{|c|}{$\begin{array}{c}1 \text { to } 3 \\
\text { Fluid } \\
\text { Hand tamped } \\
11 / 2 \text { inches }\end{array}$} & \multicolumn{5}{|c|}{$\begin{array}{c}1 \text { to } 3 \text { sand cement } \\
\text { Fluid } \\
\text { Hand tamped } \\
11 / 2 \text { inches }\end{array}$} & \multicolumn{5}{|c|}{$\begin{array}{c}1 \text { to } 3 \\
\text { Plastic } \\
\text { Machine made } \\
7 / 8 \text { inch }\end{array}$} \\
\hline Series number & \multicolumn{5}{|c|}{14} & \multicolumn{5}{|c|}{15} & \multicolumn{5}{|c|}{7} \\
\hline Year of tests & 1914 & 1915 & 1916 & 1919 & 1923 & 1914 & 1915 & 1916 & 1919 & 1923 & 1914 & 1915 & 1916 & 1919 & 1923 \\
\hline $\begin{array}{l}\text { Columbia, Mo } \\
\text { Crookston, Minn }\end{array}$ & $\begin{array}{l}2,447 \\
2,765 \\
\end{array}$ & $\begin{array}{l}2,575 \\
2,570 \\
\end{array}$ & $\begin{array}{l}2,420 \\
3,115 \\
\end{array}$ & $\begin{array}{l}1,940 \\
3,510\end{array}$ & $\begin{array}{l}2,360 \\
3,040 \\
\end{array}$ & $\begin{array}{l}1,565 \\
1,545\end{array}$ & $\begin{array}{l}1,400 \\
1,380\end{array}$ & 1,625 & $\begin{array}{l}1,445 \\
1,750\end{array}$ & $\begin{array}{l}1,575 \\
1,625\end{array}$ & $\begin{array}{l}1,175 \\
1,465\end{array}$ & $\begin{array}{l}1,275 \\
1,230\end{array}$ & $\begin{array}{l}1,330 \\
1,395\end{array}$ & $\begin{array}{r}970 \\
1,310\end{array}$ & 1,225 \\
\hline $\begin{array}{l}\text { Grand average } \\
\text { Maximum individual } \\
\text { Minimum individual }\end{array}$ & $\begin{array}{l}2,606 \\
2,780 \\
2,340\end{array}$ & $\begin{array}{l}2,575 \\
3,080 \\
2,070\end{array}$ & $\begin{array}{l}2,770 \\
3,400 \\
1,965\end{array}$ & $\begin{array}{l}2,725 \\
3,900 \\
1,680\end{array}$ & $\begin{array}{l}2,700 \\
3,220 \\
2,320\end{array}$ & $\left\{\begin{array}{l}1,555 \\
1,770 \\
1,320\end{array}\right.$ & $\left\{\begin{array}{l}1,390 \\
1,660 \\
1,140\end{array}\right.$ & $\begin{array}{l}1,670 \\
2,035 \\
1,250\end{array}$ & $\left\{\begin{array}{l}1,600 \\
2,20 ? \\
1,300\end{array}\right.$ & $\begin{array}{l}1,600 \\
1,630 \\
1,570\end{array}$ & $\begin{array}{l}1,320 \\
1,515 \\
1,145\end{array}$ & $\begin{array}{l}1,255 \\
1,360 \\
1,190\end{array}$ & $\begin{array}{l}1,360 \\
1,575 \\
1,200\end{array}$ & $\begin{array}{r}1,140 \\
1,440 \\
850\end{array}$ & $\begin{array}{l}1,160 \\
1,320 \\
1,080\end{array}$ \\
\hline
\end{tabular}

\section{EXPOSED TO ALKALI WATER}

Garland, Wyo_______ 2, $600 \mid 2,5452,6752,8602,7851,4851,3051,7251,7851,7501,4001,2501,0751,0601,260$ Fort Shaw, Ulont_L $2,8302,5302,6002,6303,0451,5301,4451,5801,5451,8851,2451,3151,3551,3451,380$ Sunnyside 2, 495 . Y 2, 295 A riz _ 2 Roswell, N. Mex_._._2, $7352,4352,8303,025$ (1) 1, $6101,3551,7852,030$ (1) 1, $3208251,3251,120$ (1) Montrose, Colo Grand Junction, Colo _ 2, 7202, 235 2, $8503,1702,4301,7401,0951,7401,3201,1751,2551,0151,4701,3651,445$ Huntington, Utah____ 2, $8353,1852,9002,7302,5101,9151,4251,6801,960 \quad 01,5351,4901,3701,1401,400$

Grand average_..._._. 2, 705 2,745 2,880 3, $0552,9101,5651,4051,5801,6451,2301,3301,2051,3091,2501,395$ Maximum individual $3,1753,1903,4803,9403,5302,1052,0002,0952,2002,9501,6051,5151,7151,7401,570$ Minimum individual 2, $2652,2752,1452,4201,8501,2201,190 \quad 6551,290 \quad 0 \quad 900 \quad 670 \quad 950 \quad 7901,130$

1 No test.

EXPOSED TO FRESH WATER

\begin{tabular}{|c|c|c|c|c|c|c|c|c|c|c|c|c|c|c|c|}
\hline $\begin{array}{l}\text { Proportion } \\
\text { Consistency } \\
\text { Method of molding. } \\
\text { Wall thickness } \\
\text { Special treatment }\end{array}$ & \multicolumn{5}{|c|}{$\begin{array}{c}1 \text { to } 4 \\
\text { Plastic } \\
\text { Machine made } \\
7 / 8 \text { inch }\end{array}$} & \multicolumn{5}{|c|}{$\begin{array}{c}1 \text { to } 11 / 2 \\
\text { Plastic } \\
\text { Machine made } \\
7 / 8 \text { inch }\end{array}$} & \multicolumn{5}{|c|}{$\begin{array}{c}1 \text { to } 11 / 2 \\
\text { Plastic } \\
\text { Machine made } \\
7 / 8 \text { inch }\end{array}$} \\
\hline Series number & \multicolumn{5}{|c|}{8} & \multicolumn{5}{|c|}{9} & \multicolumn{5}{|c|}{10} \\
\hline Year of tests_... & 1914 & 1915 & 1916 & 1919 & 1923 & 1914 & 1915 & 1916 & 1919 & 1923 & 1914 & 1915 & 1916 & 1919 & 1923 \\
\hline $\begin{array}{l}\text { Columbia, Mo } \\
\text { Crookston, Minn }\end{array}$ & $\begin{array}{r}1,020 \\
995 \\
\end{array}$ & $\begin{array}{r}1,155 \\
985\end{array}$ & $\begin{array}{r}960 \\
1,110\end{array}$ & $\begin{array}{l}715 \\
695\end{array}$ & $\begin{array}{l}835 \\
(1)\end{array}$ & $\begin{array}{l}1,615 \\
1,580\end{array}$ & $\begin{array}{l}1,825 \\
1,635\end{array}$ & $\begin{array}{l}1,510 \\
1,785\end{array}$ & $\begin{array}{l}1,140 \\
1,015\end{array}$ & $\begin{array}{l}1,295 \\
1,570\end{array}$ & $\begin{array}{l}1,780 \\
1,815\end{array}$ & $\begin{array}{l}1,620 \\
1,325\end{array}$ & $\begin{array}{l}1,395 \\
1,545\end{array}$ & $5 \quad 1,145$ & $\begin{array}{l}1,415 \\
1,635\end{array}$ \\
\hline $\begin{array}{l}\text { Grand average } \\
\text { Maximum individual } \\
\text { Minimum individual }\end{array}$ & $\begin{array}{r}1,010 \\
1,075 \\
950\end{array}$ & $\begin{array}{r}1,070 \\
1,280 \\
880\end{array}$ & $\begin{array}{r}1,035 \\
1,240 \\
870\end{array}$ & $\begin{array}{l}705 \\
850 \\
590\end{array}$ & $\begin{array}{l}835 \\
850 \\
820\end{array}$ & $\begin{array}{l}1,600 \\
1,705 \\
1,505\end{array}$ & $\begin{array}{l}1,730 \\
1,950 \\
1,470\end{array}$ & $\begin{array}{l}1,650 \\
1,945 \\
1,425\end{array}$ & $\begin{array}{r}1,080 \\
1,350 \\
775\end{array}$ & $\begin{array}{l}1,435 \\
1,570 \\
1,290\end{array}$ & $\begin{array}{l}1,795 \\
1,870 \\
1,695\end{array}$ & $\begin{array}{l}1,475 \\
1,680 \\
1,250\end{array}$ & $\begin{array}{l}1,470 \\
1,875 \\
1,070\end{array}$ & $\begin{array}{l}0 \\
5 \\
5 \\
0 \\
0\end{array}$ & $\begin{array}{l}1,525 \\
1,690 \\
1,410\end{array}$ \\
\hline
\end{tabular}

\section{EXPOSED TO ALKALI WATER}

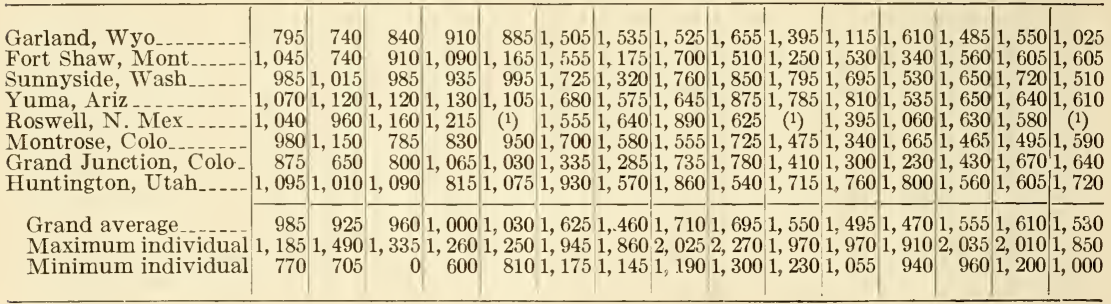


TABLE 7.-Average results of crushing tests of experimental cement drain tile-Con. EXPOSED TO FRESH WATER

\begin{tabular}{|c|c|c|c|c|c|c|c|c|c|c|c|c|c|c|c|}
\hline $\begin{array}{l}\text { Proportion } \\
\text { Consistency } \\
\text { Method of molding.-. } \\
\text { Wall thickness } \\
\text { Special treatment..... }\end{array}$ & \multicolumn{5}{|c|}{$\begin{array}{c}1 \text { to } 3 \\
\text { Plastic } \\
\text { Machine made } \\
7 / 8 \text { inch }\end{array}$} & \multicolumn{5}{|c|}{$\begin{array}{c}1 \text { to } 4 \\
\text { Plastic } \\
\text { Machine made } \\
7 / 8 \text { inch }\end{array}$} & \multicolumn{5}{|c|}{$\begin{array}{c}1 \text { to } 21 / 2 \\
\text { Plastic } \\
\text { Machine made } \\
7 / 8 \text { inch }\end{array}$} \\
\hline Series number....... & \multicolumn{5}{|c|}{11} & \multicolumn{5}{|c|}{$1 ?$} & \multicolumn{5}{|c|}{13} \\
\hline Year of tests & 1914 & 1915 & 1916 & 1919 & 1923 & 1914 & 1915 & 1916 & 1919 & 1923 & 1914 & 1915 & 1916 & 1919 & 1923 \\
\hline $\begin{array}{l}\text { Columbia, Mo....... } \\
\text { Crookston, Minn.... }\end{array}$ & $\begin{array}{l}1,200 \\
1,355\end{array}$ & $\begin{array}{l}1,300 \\
1,275\end{array}$ & $\begin{array}{l}1,370 \\
1,480\end{array}$ & 1,110 & $\begin{array}{r}940 \\
1,385\end{array}$ & $\begin{array}{l}1,170 \\
1,035\end{array}$ & $\begin{array}{l}1,125 \\
1,320\end{array}$ & $\begin{array}{l}1,070 \\
1,215\end{array}$ & $\begin{array}{l}830 \\
760\end{array}$ & $\begin{array}{r}760 \\
1,155\end{array}$ & $\begin{array}{l}1,470 \\
1,435\end{array}$ & $\begin{array}{l}1,415 \\
1,600\end{array}$ & $\begin{array}{l}1,375 \\
1,420\end{array}$ & $\begin{array}{l}1,195 \\
1,160\end{array}$ & $\begin{array}{l}1,270 \\
1,345\end{array}$ \\
\hline $\begin{array}{l}\text { Grand average } \\
\text { Maximum individual } \\
\text { Minimum individual }\end{array}$ & $\begin{array}{l}1,278 \\
1,440 \\
1,200\end{array}$ & $\begin{array}{l}1,290 \\
1,540 \\
1,010\end{array}$ & $\begin{array}{l}1,425 \\
1,595 \\
1,255\end{array}$ & $\begin{array}{r}1,030 \\
1,300 \\
500\end{array}$ & $\begin{array}{r}1,160 \\
1,480 \\
720\end{array}$ & $\begin{array}{l}1,104 \\
1,200 \\
920\end{array}$ & $\begin{array}{l}1,220 \\
1,400 \\
1,280\end{array}$ & $\begin{array}{l}1,140 \\
1,335 \\
1,000\end{array}$ & $\begin{array}{r}795 \\
1,190 \\
400\end{array}$ & $\begin{array}{l}960 \\
1,240 \\
720\end{array}$ & $\begin{array}{l}1,455 \\
1,485 \\
1,405\end{array}$ & $\begin{array}{l}1,510 \\
1,870 \\
1,230\end{array}$ & $\begin{array}{l}1,395 \\
1,545 \\
1,220\end{array}$ & $\begin{array}{r}1,180 \\
2,000 \\
690\end{array}$ & $\begin{array}{l}1,310 \\
1,390 \\
1,240\end{array}$ \\
\hline
\end{tabular}

EXPOSED TO ALKALI WATER

Garland, Wyo_._._. $|1,265| 1,445|1,2951,385| 1,215|650 \quad 865| 470 \quad 940 \quad 760|1,140| 1,320|1,4801,520| 1,415$ Fort Shaw, Mont... 1, $4251,3201,4201,3451,4301,0101,2351,0001,120$ 985 1, $2101,3301,4601,4551,170$ Sunnyside, Wash_._. $1,3501,1151,5201,3601,2151,0351,1201,1201,9001,1951,4451,7401,5551,5051,680$ Yuma, Ariz ..... 1, $3651,5151,3501,4351,480.9851,1451,1401,1101,3001,1901,4601,4201,4601,890$ Roswell, N. Mex... 1, 435 1, $0451,4901,505{ }^{\left({ }^{(}\right)} 1,0651,1201,1801,185{ }^{(1)} 1,4551,3301,5851,500(1)$ Montrose, Colo_..... 1, 195 1, $2851,3501,3301,5451,0001,205 \quad 5203359851,4951,0001,0001,3951,470$ Grand Junction, Colo__ 1, 325 1, 055 1, 360 1, 350 1, 275 1, $150 \quad 880$ 1, 090 1, 170 1, 1201,250 1, 330 1, $2101,3751,240$ Huntington, Utah_____ 1, 572 1, 615 1, 410 1, 390 1, 360 1, 1351,025960 1, 0851 1, $0851,4851,6501,3451,6651,785$

Grand average_...... $\overline{1,370} \overline{1,300} \overline{1,400} \overline{1,390} \overline{1,360} \overline{1,005} \overline{1,075} \overline{935} \overline{980} \overline{1,060} \overline{1,335} \overline{1,395} \overline{1,380} \overline{1,485} \overline{1,520}$

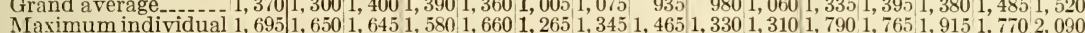

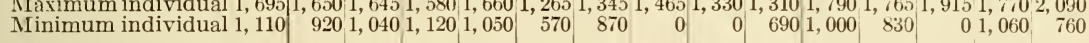

\begin{tabular}{|c|c|c|c|c|c|c|c|c|c|c|c|c|c|}
\hline \multicolumn{14}{|l|}{1 No test. } \\
\hline $\begin{array}{l}\text { Proportion } \\
\text { Consistency } \\
\text { Method of molding. } \\
\text { Wall thickness. } \\
\text { Special treatment... }\end{array}$ & \multicolumn{5}{|c|}{$\begin{array}{c}1 \text { to } 4 \\
\text { Plastic } \\
\text { Machine made } \\
7 / 8 \text { inch }\end{array}$} & \multicolumn{4}{|c|}{$\begin{array}{c}1 \text { to } 11 / 2 \\
\text { Quaking } \\
\text { Machine made } \\
7 / 8 \text { inch } \\
\text { Jigging machine }\end{array}$} & \multicolumn{4}{|c|}{$\begin{array}{c}1 \text { to } 2 \\
\text { Quaking } \\
\text { Machine made } \\
7 / 8 \text { inch } \\
\text { Jigging machine }\end{array}$} \\
\hline Series number -.- & \multicolumn{5}{|c|}{16} & \multicolumn{4}{|c|}{17} & \multicolumn{4}{|c|}{18} \\
\hline Year of tests & 1914 & 1915 & 1916 & 1919 & 1923 & 1915 & 1916 & 1919 & 1923 & 1915 & 1916 & 1919 & 1923 \\
\hline $\begin{array}{l}\text { Columbia, Mo-.-- } \\
\text { Crookston, Minn.-- }\end{array}$ & $\begin{array}{r}1,075 \\
940 \\
\end{array}$ & $\begin{array}{l}1,210 \\
1,000\end{array}$ & $\begin{array}{l}1,265 \\
1,135\end{array}$ & $\begin{array}{l}835 \\
915\end{array}$ & $\begin{array}{r}645 \\
1,090 \\
\end{array}$ & $\begin{array}{l}1,475 \\
1,320\end{array}$ & $\begin{array}{l}1,235 \\
1,440\end{array}$ & $\begin{array}{c}1,150 \\
\left({ }^{2}\right)\end{array}$ & $\begin{array}{l}(2) \\
(2)\end{array}$ & $\begin{array}{l}1,345 \\
1,295\end{array}$ & $\begin{array}{l}1,145 \\
1,590\end{array}$ & $\begin{array}{c}1.090 \\
\left({ }^{2}\right)\end{array}$ & $\begin{array}{c}1,305 \\
\left.{ }^{2}\right)\end{array}$ \\
\hline $\begin{array}{l}\text { Grand average } \\
\text { Maximum indi- } \\
\text { vidual } \\
\text { Minimum indi- } \\
\text { vidual. }\end{array}$ & $\begin{array}{l}1,010 \\
1,156\end{array}$ & $\begin{array}{r}1,105 \\
1,430 \\
940\end{array}$ & $\begin{array}{r}1,200 \\
1,375 \\
940\end{array}$ & $\begin{array}{r}875 \\
1,100 \\
650\end{array}$ & $\begin{array}{r}865 \\
1,110 \\
630\end{array}$ & $\begin{array}{l}1,400 \\
1,570 \\
1,200\end{array}$ & $\begin{array}{l}1,585 \\
1,180\end{array}$ & $\begin{array}{l}1,150 \\
1,250 \\
1,050\end{array}$ & & $\begin{array}{l}1,320 \\
1,410 \\
1,260\end{array}$ & $\begin{array}{l}1,370 \\
1,675 \\
1,030\end{array}$ & $\begin{array}{l}1,090 \\
1,120 \\
1,060\end{array}$ & $\begin{array}{l}1,380 \\
1,230\end{array}$ \\
\hline
\end{tabular}

\section{EXPOSED TO ALKALI WATER}

Garland, Wyo-Fort Shaw, Mont Sunnyside, Wash

Yuma, Ariz.

Roswell, N. Mex

Montrose, Colo

Grand Junction,

Colo Junction,

Huntington, Utah.

Grand average

Maximum indi-

vidual.

Minimum indi-

vidual

\begin{tabular}{r|r|r|r|r|r|r|r|r|r|r|r|r|r|r|r}
\hline 690 & 830 & 645 & 885 & 0 & 1,310 & 1,475 & 1,735 & $(1)$ & 1,260 & 1,385 & 1,560 & $(1)$ \\
980 & 880 & 1,020 & 1,242 & 830 & 1,465 & 1,470 & 1,680 & 1,620 & 1,295 & 1,510 & 1,805 & 1,780 \\
1,002 & 850 & 510 & 1,135 & 1,205 & 1,460 & 1,590 & 1,700 & 1,770 & 1,415 & 1,420 & 1,450 & 1,330 \\
1,050 & 1,130 & 1,240 & 1,225 & 1,255 & 1,530 & 1,590 & 1,515 & 1,320 & 1,305 & 1,350 & 1,610 & 1,570 \\
1,077 & 865 & 1,085 & 975 & $(1)$ & 1,260 & 1,220 & 1,440 & $(1)$ & 1,190 & 1,480 & 1,435 & $(1)$ \\
777 & 840 & 490 & 0 & 400 & 1,320 & 1,240 & 0 & 0 & 1,430 & 1,240 & 975 & 0 \\
760 & 1,100 & 490 & 0 & 600 & 1,315 & 1,485 & 1,630 & 1,530 & 1,395 & 1,400 & 1,550 & 1.700 \\
957 & 1,400 & 1,055 & 1,175 & 945 & 1,690 & 1,695 & 1,275 & 1,710 & 1,685 & 1,320 & 1,165 & 1,735 \\
\hline 915 & 985 & 815 & 820 & 750 & 1,420 & 1,460 & 1,370 & 1,325 & 1,370 & 1,390 & 1,445 & 1,350 \\
\hline 145 & 1,400 & 1,495 & 1,310 & 1,260 & 1,720 & 1,795 & 1,810 & 2,000 & 1,590 & 1,695 & 1,880 & 2,000 \\
\hline 490 & 770 & 0 & 0 & 0 & 1,140 & 970 & 0 & 0 & 1,045 & 1,050 & 0 & 0
\end{tabular}

1 No test.
2 No tests; tile had been cracked by water freezing in line. 
TABLE 7.-Average results of crushing tests of experimental cement drain tile-Con. EXPOSED TO FRESH WATER

\begin{tabular}{|c|c|c|c|c|c|c|c|}
\hline $\begin{array}{l}\text { Proportion } \\
\text { Consistency } \\
\text { Method of molding } \\
\text { Wall thickness } \\
\text { Special treatment }\end{array}$ & \multicolumn{3}{|c|}{$\begin{array}{l}1 \text { to } 21 / 2 \\
\text { Plastic } \\
\text { Machine made } \\
7 / 8 \text { inch }\end{array}$} & \multicolumn{4}{|c|}{$\begin{array}{l}1 \text { to } 21 / 2 \\
\text { Plastic } \\
\text { Machine made } \\
7 / 8 \text { inch }\end{array}$} \\
\hline Series number.... & & 19 & & & 20 & & 21 \\
\hline Year of tests.... & 1916 & 1919 & 1923 & 1916 & 1919 & 1923 & 1923 \\
\hline $\begin{array}{l}\text { Columbia, Mo } \\
\text { Crookston, Minn }\end{array}$ & $\begin{array}{l}1,310 \\
1,530\end{array}$ & $\begin{array}{l}1,425 \\
2,125\end{array}$ & $\begin{array}{l}1,555 \\
1,650\end{array}$ & $\begin{array}{l}1,320 \\
1,590\end{array}$ & $\begin{array}{l}1,390 \\
1,720\end{array}$ & $\begin{array}{l}1,390 \\
1,870\end{array}$ & $\begin{array}{l}1,045 \\
1,205\end{array}$ \\
\hline $\begin{array}{l}\text { Grand average } \\
\text { Maximum individual } \\
\text { Minimum individual }\end{array}$ & $\begin{array}{l}1,420 \\
1,605 \\
1,140\end{array}$ & $\begin{array}{l}1,775 \\
2,250 \\
1,370\end{array}$ & $\begin{array}{l}1,600 \\
1,660 \\
1,450\end{array}$ & $\begin{array}{l}1,455 \\
1,795 \\
1,210\end{array}$ & $\begin{array}{l}1,555 \\
1,850 \\
1,250\end{array}$ & $\begin{array}{l}1,630 \\
1,870 \\
1,350\end{array}$ & $\begin{array}{r}1,125 \\
1,220 \\
970\end{array}$ \\
\hline
\end{tabular}

EXPOSED TO ALKALI WATER

\begin{tabular}{|c|c|c|c|c|c|c|c|}
\hline $\begin{array}{l}\text { Garland, Wyo } \\
\text { Fort Shaw, Mont } \\
\text { Sunnyside, Wash } \\
\text { Yuma, Ariz } \\
\text { Roswell, N, Mex } \\
\text { Montrose, Colo } \\
\text { Grand Junction, Colo } \\
\text { Huntington, Utah. }\end{array}$ & $\begin{array}{l}1,585 \\
1,560 \\
1,490 \\
1,530 \\
1,765 \\
1,860 \\
1,620 \\
1,790\end{array}$ & $\begin{array}{l}1,775 \\
1,720 \\
1,575 \\
1,775 \\
1,595 \\
2,010 \\
1,575 \\
1,700\end{array}$ & $\begin{array}{l}(1) \\
1,925 \\
1,575 \\
1,755 \\
(1) \\
2,170 \\
1,840 \\
1,710\end{array}$ & $\begin{array}{l}1,595 \\
1,620 \\
1,620 \\
1,600 \\
1,570 \\
1,725 \\
1,465 \\
1,550\end{array}$ & $\begin{array}{l}1,760 \\
1,605 \\
1,550 \\
1,705 \\
1,555 \\
1,880 \\
1,725 \\
1,465\end{array}$ & $\begin{array}{l}(1) \\
1,870 \\
1,580 \\
1,725 \\
(1) \\
1,930 \\
1,770 \\
2,050\end{array}$ & $\begin{array}{r}1,145 \\
1,195 \\
1,310 \\
1,435 \\
(1) \\
980 \\
1,040 \\
1,475\end{array}$ \\
\hline $\begin{array}{l}\text { Grand averagc } \\
\text { Maximum individual } \\
\text { Minimum individual }\end{array}$ & $\begin{array}{l}1,655 \\
1,995 \\
1,335\end{array}$ & $\begin{array}{l}1,715 \\
2,070 \\
1,550\end{array}$ & $\begin{array}{l}1,830 \\
2,190 \\
1,560\end{array}$ & $\begin{array}{l}1,595 \\
1,805 \\
1,345\end{array}$ & $\begin{array}{l}1,655 \\
1,890 \\
1,400\end{array}$ & $\begin{array}{l}1,820 \\
2,050 \\
1,510\end{array}$ & $\begin{array}{r}1,225 \\
1,500 \\
860\end{array}$ \\
\hline
\end{tabular}

1 No test.

GRAND AVERAGES

EXPOSED TO FRESH WATER

\begin{tabular}{|c|c|c|c|c|c|c|c|c|c|c|}
\hline \multirow[b]{2}{*}{ Year of tests. } & \multicolumn{5}{|c|}{ Series 1 to 16 only. } & \multicolumn{5}{|c|}{ All tile } \\
\hline & 1914 & 1915 & 1916 & 1919 & 1923 & 1914 & 1915 & 1916 & 1919 & 1923 \\
\hline $\begin{array}{l}\text { Columbia, Mo } \\
\text { Crookston, Minn }\end{array}$ & $\begin{array}{l}1,870 \\
1,955\end{array}$ & $\begin{array}{l}2,020 \\
2,005\end{array}$ & $\begin{array}{l}1,840 \\
2,185\end{array}$ & $\begin{array}{l}1,585 \\
1,895\end{array}$ & $\begin{array}{l}1,755 \\
2,010\end{array}$ & $\begin{array}{l}1,870 \\
1,955\end{array}$ & $\begin{array}{l}1,950 \\
1,930\end{array}$ & $\begin{array}{l}1,725 \\
2,055\end{array}$ & $\begin{array}{l}1,520 \\
1,900\end{array}$ & $\begin{array}{l}1,670 \\
1,933\end{array}$ \\
\hline
\end{tabular}

EXPOSED TO ALKALI WATER

\begin{tabular}{|c|c|c|c|c|c|c|c|c|c|c|}
\hline Garland, Wyo. & 1,820 & 1,713 & 1,805 & 1,950 & 1,925 & 1,820 & 1,665 & 1,750 & 1,500 & 1,880 \\
\hline Fort Shaw, Mont & 1,835 & 1,855 & 1,885 & 1,950 & 2,090 & 1,835 & 1,800 & 1,820 & 1,900 & 1,990 \\
\hline Sunnyside, Wash. & 1,900 & 1,915 & 1,985 & 1,980 & 2,220 & 1,900 & 1,860 & 1,895 & 1,900 & 2,050 \\
\hline Yuma, Ariz $\ldots . .$. & 1,860 & 1,985 & 1,970 & 2,105 & 2,145 & $1,86^{\circ}$ & $\cdot 1,925$ & 1,875 & 2,015 & 2,005 \\
\hline Roswell, N. Mex . & 1,945 & 1,735 & 2,090 & 2,090 & & 1,945 & 1,680 & 1,975 & 1,975 & \\
\hline Montrose, Colo & 1,930 & 1,825 & 1,760 & 1,980 & 1,825 & 1,930 & 1,780 & 1,710 & 1,830 & 1,630 \\
\hline Grand Junction, Colo & 1,770 & 1,500 & 1,800 & 1,560 & 1,565 & 1,770 & 1,485 & 1,740 & 1,570 & 1,570 \\
\hline Huntington, Utah $\ldots \ldots$ & 1,940 & 1,980 & 1,995 & 1,820 & 1,960 & 1,940 & 1,945 & 1,915 & 1,735 & 1,900 \\
\hline
\end{tabular}

\section{CONCRETE BLOCKS}

The inspection made in 1923 of concrete blocks first placed in exposure to alkali waters in 1915 represented the third examination of such installations and determined condition at the termination of the eighth year exposure period. For details of condition reference is made to Table 10 . 
Referring to Table 2, it will be noted that several variables, such as concrete composition, and methods of molding and curing were put under observation for determination of respective effects on relative durability under alkali exposure, while Table 8 indicates the variations in the several alkali exposure conditions.

Series A.-Made of selected aggregate at Denver, Colo., in proportions $1: 1 \frac{1}{2}: 3$ and $1: 21 / 2: 5$, of uniform plastic consistency, cast in smooth wood, rough wood, or smooth metal forms and cured for at least one month prior to shipment and installation in alkali water.

The superior resistive properties of the specimens cast in smooth forms is demonstrated on the field evidence. Under the same exposure conditions the richer mix indicated superiority over the leaner mix; but where exposure conditions were severe even the richer mixture underwent a degree of disintegration characterized as destructive. The marked superiority of Portland cement concrete over natural and sand cement concretes, in respect to durability in alkali ground waters, was indicated by the relative resistance under parallel exposure.

Series B.-Made of aggregate found locally near installation site in commercial quantities, other factors, such as proportions, method of fabrication, and period of curing prior to alkali exposure, parallel with the A series. Series B was projected partly to derelop local information for the Reclamation Service and also to increase the range of the durability investigation by introduction of rariation in aggregate quality.

$A$ in the case of series $A$, the richer mix proved the more durable at all sites where alkali exposure condition was severe. Some of the local aggregates of this series yielded a concrete exhibiting about the same degree of tolerance for a specific alkali ground water as the corresponding specimens of Series $\mathrm{A}$. Where exposure conditions were serere, as at Mesquite, N. Mex., all blocks of all series were badly disintegrated, while at Fallon, Ner., a relatively mild exposure site, all specimens of all series were in perfect condition after eight year's' contact with local ground water.

Series C.-Similar in every respect to series B except that the specimens were cast in place with no precuring prior to exposure to alkali ground waters. As in the case of the other two series, the richer mix specimens proved to have a greater durability than the corresponding leaner mixtures. In general, the series $\mathrm{C}$ specimens exhibited a somewhat greater degree of resistance for any specific alkali exposure condition than the series B specimens.

The arerage chemical analysis of all water samples taken at any one concrete block installation site is included in Table 8. Since conditions were continually changing, the samples obtained at any site were not sufficient to furnish a complete record. There is no 
certainty that either the maximum or minimum concentrations have been detected at any site by means of the few samples taken.

The great variations in concentration which occur at the same time in seepage waters only a short distance from each other is illustrated in Table 9 by samples obtained at Orman in 1919. Blocks here were placed below a wasteway in soil which is usually moist, due to seepage from a canal. In 1919 a few inches of water stood over the surface of the ground surrounding the blocks. The concentration of salts in this water was 3.31 per cent. Subsoil water obtained a few feet away in the direction of the canal had a concentration of 0.51 per cent, while a large pool below the block site contained 0.93 per cent salt.

The relative constancy of composition of salts in solution at any site was found to be independent of the concentration of such salts. The full details of all analyses made of water samples taken at Orman and at Mesquite (Table 9), illustrate characteristic examples of such a relation.

TABLE S.-Analyses of surface and subsoil waters at block sites

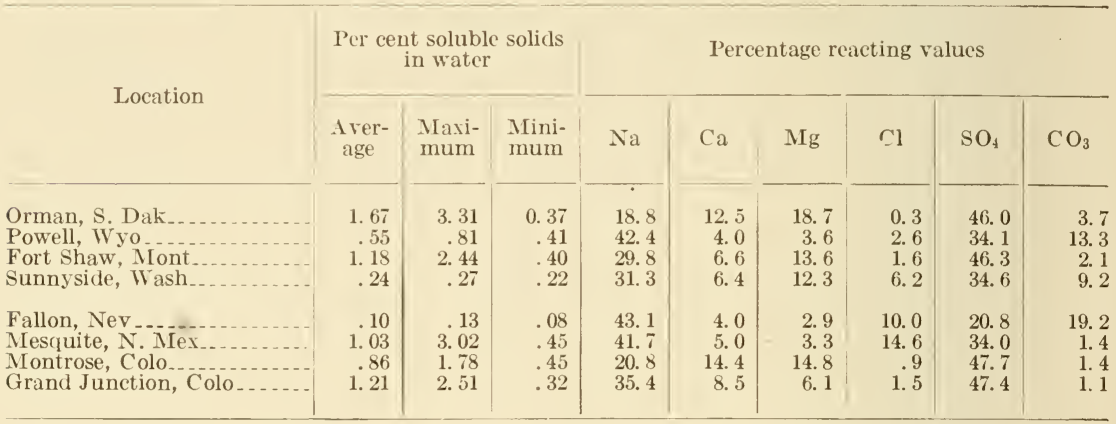

TABLE 9.-Details of analyses of surface and subsoil waters ai Orman, S. Dak., and Mesquite, N. Mex., block sites

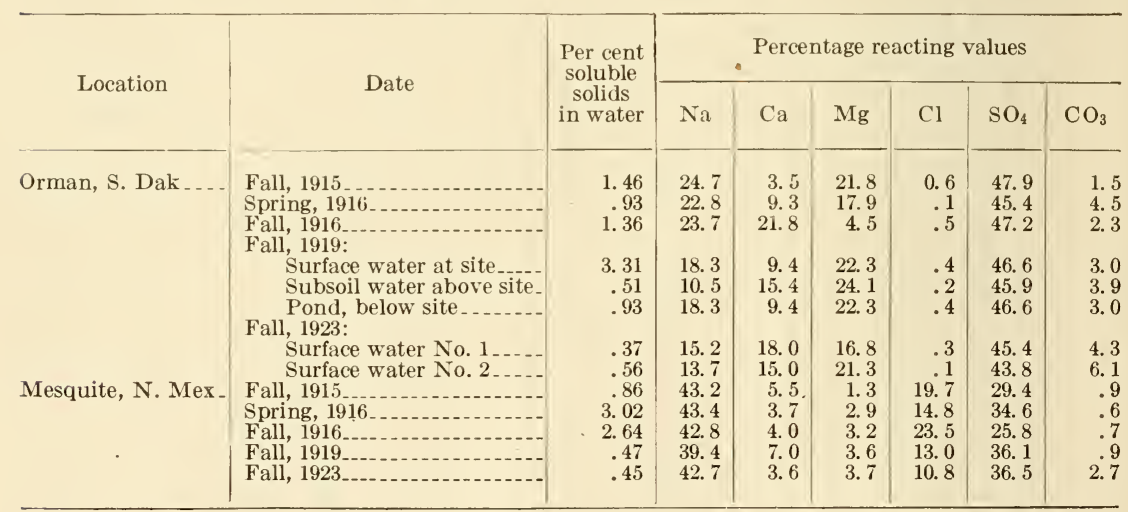


Orman, S. Dak.-The block site at Orman, moist the year around with seepage water bearing relatively high concentrations of alkali salts in solution, proved to be a severe exposure location. At the end of the eighth year of exposure only the richer mix $(1: 11 / 2: 3)$ specimens of the A series were in good condition. The leaner mix $\left(1: 2 \frac{1}{2}: 5\right)$ specimens of the same series first showed evidence of disintegration at the end of the first year of exposure and were completely broken down at the termination of the eighth year. Specimens of the B series disintegrated within a four-year exposure period, while the specimens of series $\mathrm{C}$ were either deeply shelled or scaled at the ground line or else completely destroyed at the termination of the eighth year.

Powell, Wyo.-The water level at the Powell site varied considerably, often standing as high as the top of the blocks. The average alkali environment here was not so severe as at Orman. During the first year of exposure the A series developed no signs of deterioration, while the $B$ and $C$ series indicated the first stages of disintegration such as surface scaling and pitting. By the termination of the fourth year of exposure the A series had undergone some surface attack, slightly worse by the termination of the eighth year. At this site the specimens made of local aggregate exhibited nearly the same degree of resistance for the environment as the corresponding specimens of series A made of selected Denver aggregate. Contrary to the observations made at the other sites, the specimens cast in place at Powell had somewhat less resistance to local conditions than the corresponding specimens cured for one month prior to exposure installation.

Fort Shaw, Mont.-Figure 25 shows the installation of concrete blocks in alkali-bearing seeped ground near Fort Shaw. At the termination of eight year's exposure all specimens of all series made in proportions $1: 1 \frac{1}{2}: 3$ were in good condition.

Of the $1: 2 \frac{1}{2}: 5$ proportioned specimens only representatives of series $\mathrm{C}$ were unattacked during eight years. Specimens of the A and $\mathrm{B}$ series made in the same proportions scaled and pitted somewhat during the early stages of exposure, but the rate of such attack later proved to be very slow. At this site the specimens of the $\mathrm{C}$ series cast in place proved a slight superiority over the A series, made of selected aggregate and cured for one month prior to installation.

Sunnyside, Wash.-The block site selected near Sunnyside was on the side of a small isolated pond. Analyses of water samples taken at this site indicate a relatively low and uniform concentration of salts in solution during the eight years the blocks have been in place. After four years of exposure both the A and B series showed surface scaling and shelling at the ground line, the leaner mix types to the greater extent. At the eighth year period the 1:11/2:3 proportioned 


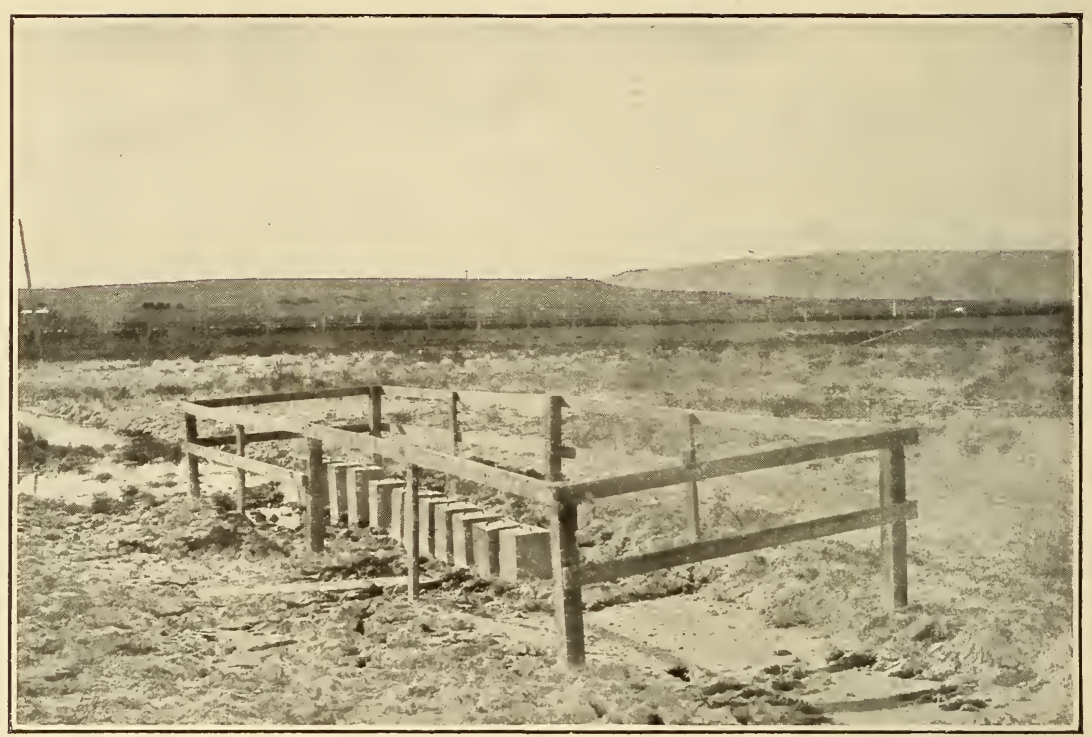

Fig. 25.-Concrete blocks in place in seeped ground near Fort Shaw, Mont., 1916. Note the alkali crust on surface of ground. Some disintegration was noted

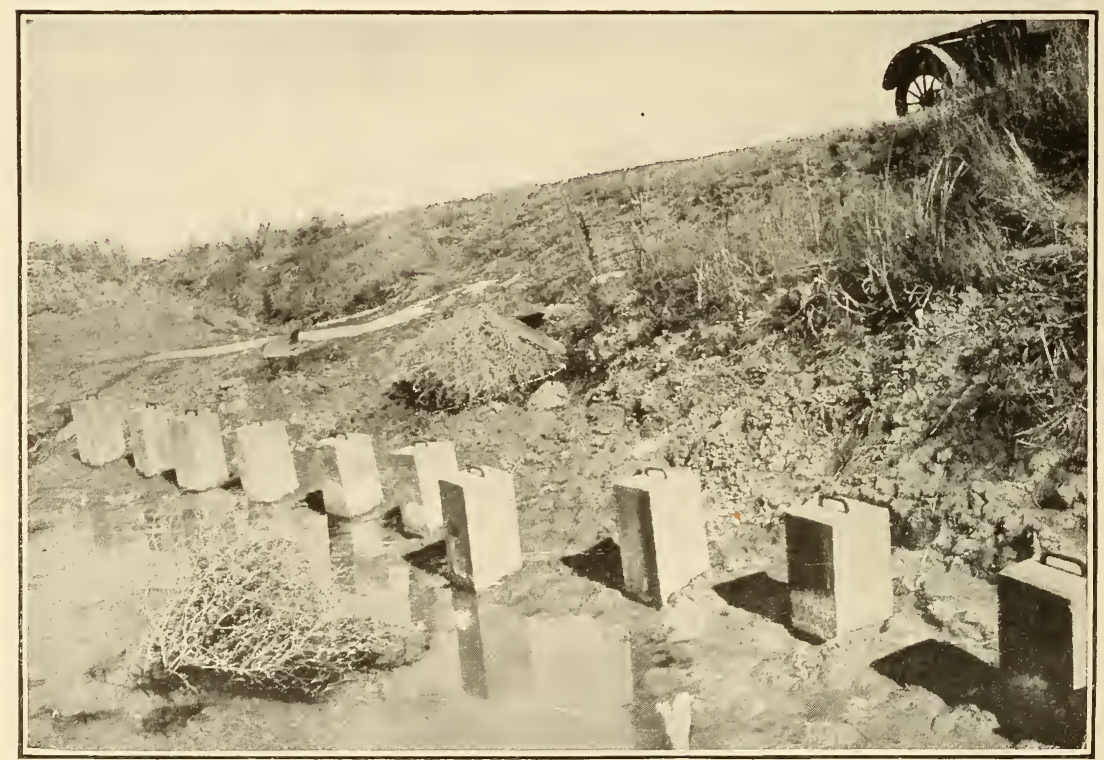

Fig. 26.-Concrete blocks in place in drainage ditch near Fallon, Nev. Note the large incrustations of alkali salts on the surfaces. The concrete is apparently unaffected 
specimens, both $\mathrm{A}$ and $\mathrm{B}$ series, were shelled out at the ground line to a depth of about one-fourth inch, while the corresponding $1: 21 / 2: 5$ proportioned specimens had undergone similar attack to the depth of about one-half inch.

Fallon, Nev.-Figure 26 illustrates the large incrustations of alkali salts on the surfaces at the Fallon site; but in such alkali as the water bears in solution at this site the carbonate radical is practically as high as the sulphate and, taking concentration into account, it is seen that the carbonate is little higher than in normal waters. It is probably significant that the Fallon site is the only location of blocks

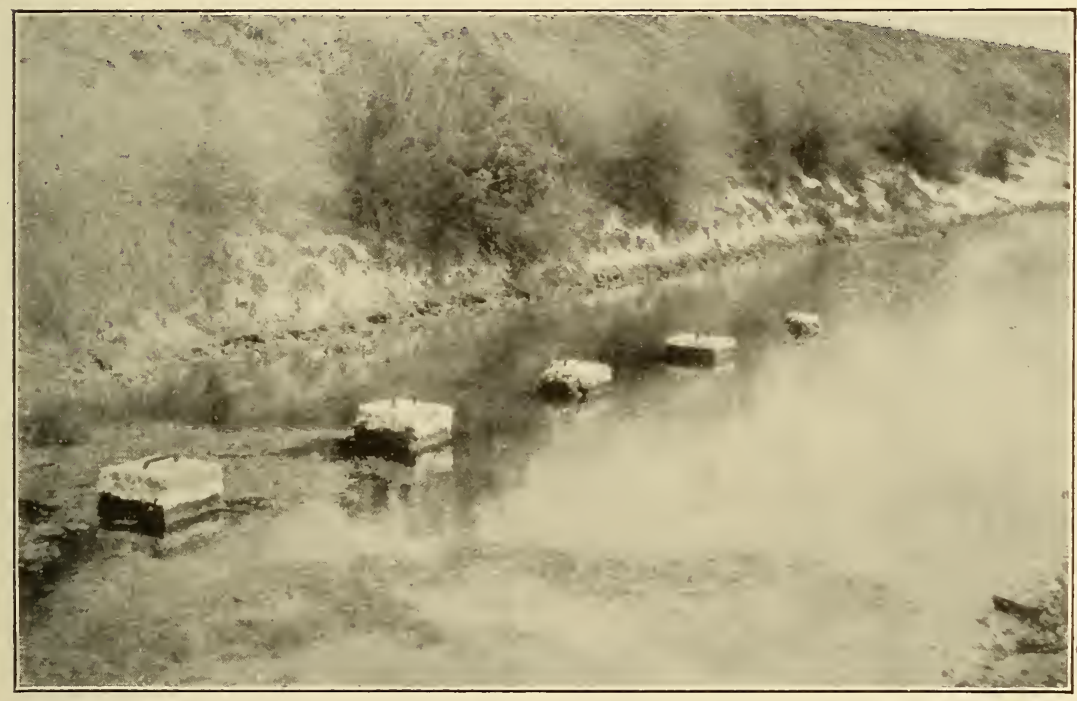

FIG. 27.-View of five blocks at Mesquite in 1919 showing cracking and disintegration

From left to right these blocks are numbered as follows: $143,147,146,54$, and 55

where the sulphate type of alkali has not overwhelmingly predominated and also the only site where the blocks underwent no apparent deterioration whatsoever during eight years of exposure.

Mesquite, N. Mex.-The site selected at Mesquite provided for partial submersion of the concrete blocks in alkaline water. Referring to Table 7 , it will be noted that the amount of alkali in the water at this site in 1916 can be characterized as an unusually high concentration. The $\mathrm{B}$ and $\mathrm{C}$ series specimens showed eridences of attack during the year 1916. After four years of exposure (see fig. 27) all specimens of all series had been seriously affected, evidenced by large cracks, pitting, shelling, or swelling. At the termination of the eighth year exposure period the entire installation of blocks was regarded as disintegrated to the point of destruction. 
Montrose, Colo. $-\Lambda$ shallow pond created by seepage from the canal of the Reclamation Service provided a site for concrete block installation near Montrose. The concentration of alkali in the pond water was subject to variation, but was invariably and orerwhelmingly, of the sulphate type. At the termination of the first year of exposure the A series of blocks indicated no deterioration, but after the fourth year the leaner proportioned specimens only were surface scaled. Of the specimens made of local aggregate only the richer proportioned specimens of the $\mathrm{C}$ series entirely resisted the local alkali environment during the four years of observations. The other specimens compounded of local aggregate were more or less scaled. At the termination of the eighth year exposure period the blocks were submerged to an extent making inspection of conditions not practicable.

Grand Junction, Colo.-At the time of installation of concrete blocks in a borrow pit just below the South Canal the indications were that seepage water from the canal would maintain at least a moist condition in the pit the year around. Howerer, at the end of the first year of specimen installation this block site dried up as the result of the silting up of the adjacent canal. The quantity of soil water present since that time at the Grand Junction site has not been sufficient to derelop the extreme conditions which the quantity of salts present in the immediate locality would seem to justify. The blocks representing the natural cement types of specimens disintegrated during three months of exposure. As was demonstrated at the other sites, the $1: 1 \frac{1}{2}: 3$ proportioned specimens of the $\mathrm{A}$ series were more resistant to the local environment than the $1: 21 / 2: 5$ mixes of the same series. The sand cement type specimens of the A series were more seriously affected than the corresponding Portland cement types. Block specimens representing local aggregate proportioned $1: 1 \frac{1}{2}: 3$ exhibited a resistance on a par with the series A specimens. Series C specimens cast in place at the site prored more resistant than corresponding specimens cured for one month prior to alkali exposure. 
TABLE 10.-Condition of concrete blocks molded and placed in 1915

[Results of inspections in 1916, 1919, and 1923]




TABLE 10.-Condition of concrete blocks molded and placed in 1915-Continued

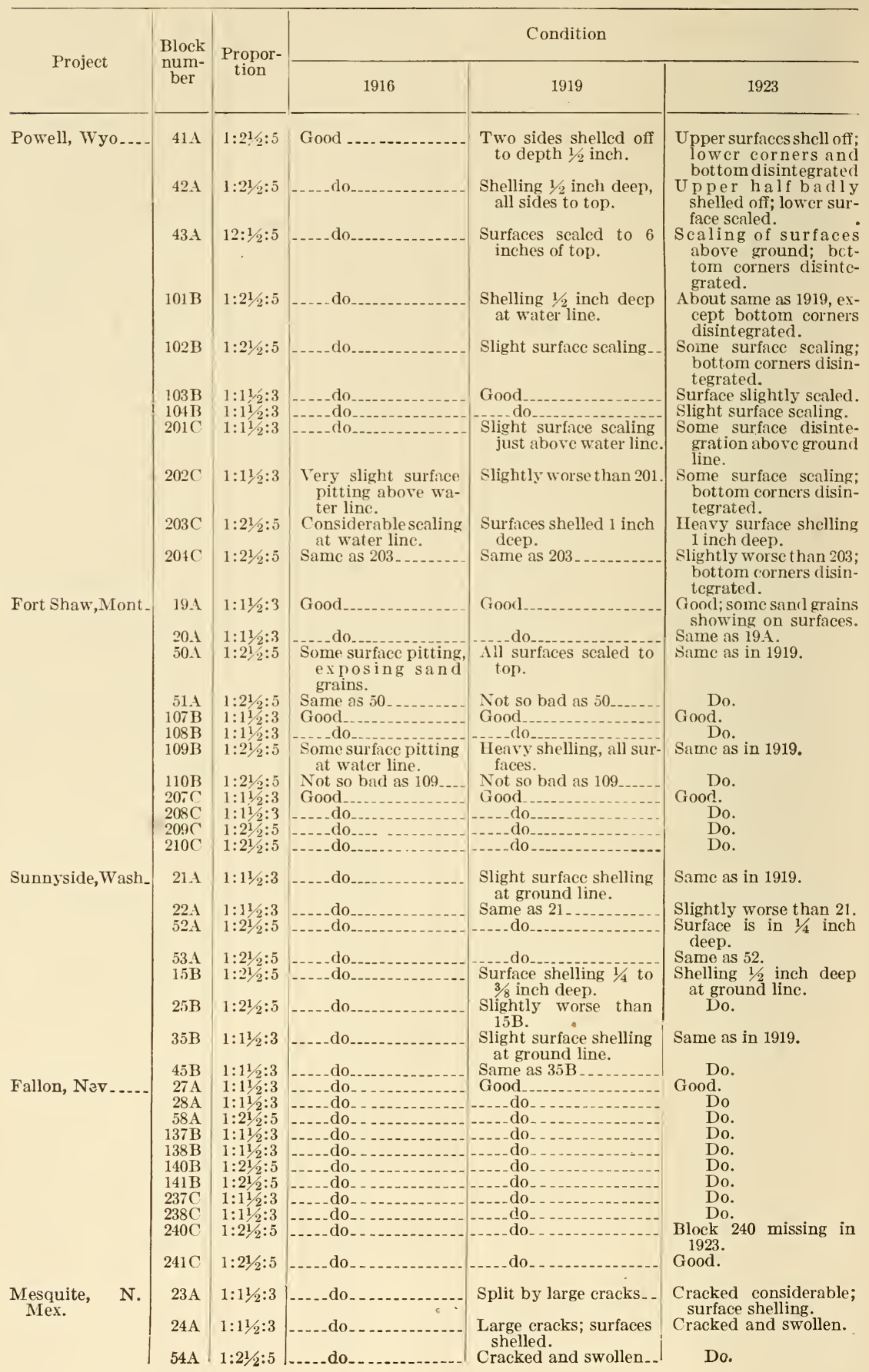


TABLE 10.-Condition of concrete blocks molded and placed in 1915-Continued

\begin{tabular}{|c|c|c|c|c|c|}
\hline \multirow{2}{*}{ Project } & \multirow{2}{*}{$\begin{array}{l}\text { Block } \\
\text { num- } \\
\text { ber }\end{array}$} & \multirow{2}{*}{$\begin{array}{l}\text { Propor- } \\
\text { tion }\end{array}$} & \multicolumn{3}{|c|}{ Condition } \\
\hline & & & 1916 & 1919 & 1923 \\
\hline $\begin{array}{l}\text { Mesquite, } \\
\text { Mex. }\end{array}$ & $\begin{array}{l}55 \mathrm{~A} \\
143 \mathrm{~B} \\
144 \mathrm{~B} \\
146 \mathrm{~B} \\
147 \mathrm{~B} \\
243 \mathrm{C} \\
244 \mathrm{C} \\
\\
246 \mathrm{C} \\
247 \mathrm{C}\end{array}$ & $\begin{array}{l}1: 1 \frac{1}{2}: 3 \\
1: 1 \frac{1}{2}: 3 \\
1: 21 / 2: 5 \\
1: 21 / 2: 5\end{array}$ & $\begin{array}{r}\text { Good _... } \\
\text { Slight surface scaling } \\
\text { Some surface scaling- } \\
\text { Slight surface scaling } \\
\text { _. }\end{array}$ & $\begin{array}{l}\text { Top sloughed off; } \\
\text { worse than 54A. } \\
\text { Cracked and swollen. } \\
\text { Badly cracked; lumps } \\
\text { easily broken off. } \\
\text { Large cracks; portion } \\
\text { of top missing. } \\
\text { Pitting of surfaces, } \\
\text { small cracks. } \\
\text { Pitted, cracked. }\end{array}$ & $\begin{array}{l}\text { No trace found. } \\
\text { Cracked and swollen. } \\
\text { Do. } \\
\text { Almost complete dis- } \\
\text { integration. } \\
\text { Do. } \\
\text { Surfaces badly shelled } \\
\text { off. } \\
\text { Better condition than } \\
243 . \\
\text { Badly cracked, pitted. } \\
\text { Do. }\end{array}$ \\
\hline Montrose, Colo & $\begin{array}{r}25 \mathrm{~A} \\
26 \mathrm{~A} \\
56 \mathrm{~A} \\
\\
57 \mathrm{~A} \\
125 \mathrm{~B} \\
\\
126 \mathrm{~B} \\
128 \mathrm{~B} \\
129 \mathrm{~B} \\
\\
225 \mathrm{C} \\
226 \mathrm{C} \\
228 \mathrm{C} \\
229 \mathrm{C}\end{array}$ & 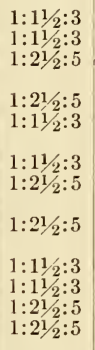 & 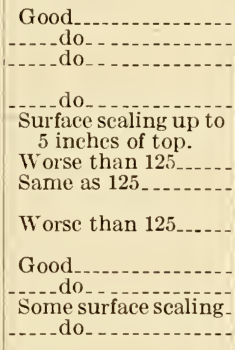 & $\begin{array}{l}\text { Good. } \\
5 \text { inches of top. } \\
\text { Decper sealing than } 56 \\
\text { Same as in } 1916 \\
\text { do } \\
\text { Shelling } 1 / 2 \text { inch decp } \\
\text { above ground line. } \\
\text { Surface shelled off } 1 \\
\text { inch deep to top. } \\
\text { Good } \\
\text { Same as in } 1916 \\
\text { do do }\end{array}$ & $\begin{array}{l}\text { No inspection } \\
\text { Do. } \\
\text { Do. } \\
\text { Do. } \\
\text { Do. } \\
\text { Do. } \\
\text { Do. } \\
\text { Do. } \\
\text { Do. } \\
\text { Do. } \\
\text { Do. } \\
\text { Do. }\end{array}$ \\
\hline $\begin{array}{l}\text { Grand Junction, } \\
\text { Colo. }\end{array}$ & $\begin{array}{r}13 \mathrm{~A} \\
14 \mathrm{~A} \\
15 \mathrm{~A} \\
16 \mathrm{~A} \\
17 \mathrm{~A} \\
18 \mathrm{~A} \\
44 \mathrm{~A} \\
45 \mathrm{~A} \\
46 \mathrm{~A} \\
47 \mathrm{~A} \\
48 \mathrm{~A} \\
\\
49 \mathrm{~A} \\
\\
63 \mathrm{~A} \\
\\
64 \mathrm{~A} \\
65 \mathrm{~A} \\
\\
66 \mathrm{~A} \\
67 \mathrm{~A} \\
\\
68 \mathrm{~A} \\
121 \mathrm{~B} \\
132 \mathrm{~B} \\
134 \mathrm{~B} \\
\\
135 \mathrm{~B} \\
303 \mathrm{~B} \\
304 \mathrm{~B} \\
305 \mathrm{~B} \\
306 \mathrm{~B} \\
231 \mathrm{C} \\
\\
232 \mathrm{C} \\
233 \mathrm{C} \\
234 \mathrm{C}\end{array}$ & $\begin{array}{l}1: 1 \frac{1}{2}: 3 \\
1: 1 \frac{1}{2}: 3 \\
1: 1 \frac{1}{2}: 3 \\
1: 11 \frac{2}{2}: 3 \\
1: 1 \frac{1}{2}: 3 \\
1: 11 / 2: 3 \\
1: 21 / 2: 5 \\
1: 21 / 2: 5 \\
1: 21 / 2: 5 \\
1: 21 / 2: 5 \\
1: 21 / 2: 5 \\
1: 21 / 2: 5 \\
1: 11 / 2: 3 \\
1: 11 \frac{1}{2}: 3 \\
1: 21 / 2: 5 \\
1: 21 / 2: 5 \\
1: 11 \frac{1}{2}: 3\end{array}$ & 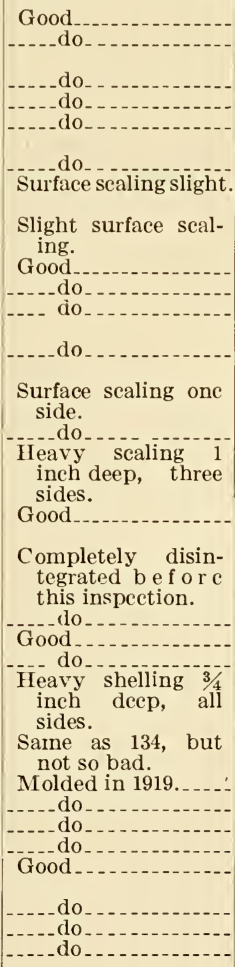 & 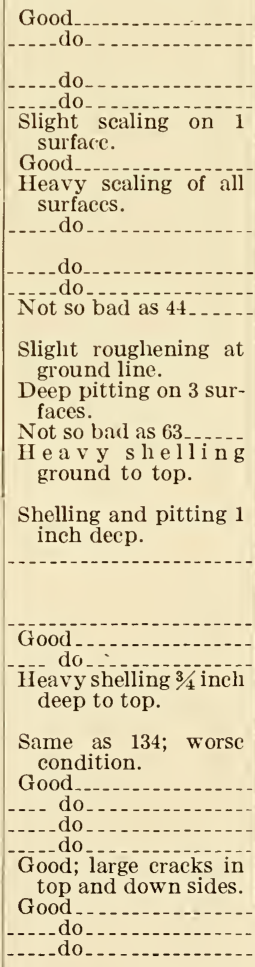 & $\begin{array}{l}\text { Good. } \\
\text { Very slight roughening } \\
\text { of surface at ground. } \\
\text { Same as } 14 \text {. } \\
\text { Good. } \\
\text { Very slight roughening } \\
\text { at ground line. } \\
\text { Do. } \\
\text { Heavy shelling of sur- } \\
\text { faces. } \\
\text { Not quite so bad as } 44 . \\
\text { Same as } 44 \text {. } \\
\text { Do. } \\
\text { Roughening at ground } \\
\text { line. } \\
\text { Not so bad as } 48 \text {. } \\
\text { Heavy shelling } 1 \text { inch } \\
\text { deep. } \\
\text { Not so bad as } 63 . \\
\text { Heavy shelling. } \\
\text { Do }\end{array}$ \\
\hline
\end{tabular}




\section{SUMMARY OF RESULTS}

\section{DRAIN TILE}

But little progress in the alkali attack since 1919, as recorded in B. S. Technologic Paper No. 214, has been observed during the 1923 inspection. Regional operations involving extensive irrigation and adequate drainage at many of the experimental drain sites have tended to reduce the severity of local exposure conditions.

Durability of cement drain tile for any given concentration appears to vary with richness of mix and consistency. Hand-tamped tile are less resistant to action than machinemade tile made of the same mortars.

Tile made with sufficient mixing water to result in such a consistency that they must be retained in the molds for several hours hare proved more durable than richer mix tile of the machinemade type of such a dry consistency that the jacket may be stripped immediately. Results to date have indicated the 1915 replacement tile (series 19 and 20), made with a combination packing and tamping machine of a consistency permitting immediate removal of the jacket, to be more resistant to alkali action than richer mixes of the same consistency marle on the packer-head type of machine or by hand. As a class it may be said that wet-mix tile hare been much less affected br alkali action than dry-mix tile.

Inspection of drain tile and concrete-structures in other localities where the alkali salts are of the chloride or carbonate types seem to justify the conclusion that these waters are not so severe as waters of the sulphate type which are found in all of our drains in the alkali districts. Results have shown that it is impossible to estimate the maximum concentrations to which tile in the drain may be exposed by analyses of water flowing in the drain. In waters of the sulphate type sererity of action appears to vary with the concentration of soluble salts. The number of types of tile affected by alkali varies roughly with concentration of water as determined by analyses of water samples taken at the outlet. In all cases where disintegration of the best quality of tile has occurred samples of the soil immediately in contact with such tile have rerealed concentrations much higher than are indicated by the drain water.

To date, one or more marked cases of disintegration have been noted in every type of tile except series 19 and 20. The fact that appreciable quantities of salt have been found in the walls of this type in some cases would indicate that this type has probably not been exposed to the extreme concentrations found for some of the test specimens of series 2,17 , and 18 . 


\section{CONCRETE BLOCKS}

The concrete blocks hare all been exposed to waters of the sulphate type. Owing to rariation and change in ground water conditions at some of the sites, some blocks hare not been exposed to the extreme conditions which might be indicated by analyses of surrounding soils. While the Denrer A series blocks hare generally been more resistant to alkali than the blocks molded on the projects, these blocks hare been seriously affected where concentrations hare been high.

As in the case of drain tile, it may be stated that sererity of action on the concrete blocks appears to rary with concentration of soluble salts. While there is no record of the maximum concentrations encountered, conditions hare been such on one project that all blocks installed may be considered as complete failures.

With the same aggregates, lean mixtures are more seriously and rapidly affected than rich mixtures. Durability appears to be dependent upon impermeability, which is mainly dependent upon richness of mix and gradation of aggregate.

\section{CONCLUSIONS}

While any conclusions drawn from the results of the inrestigation to date must be considered as tentatire, it is beliered that the scope of the work, the variety and types of concretes included, together with the widely different exposure conditions, hare resulted in extending the knowledge of what occurs when such material is exposed to alkali soils and waters. No doubt further extension of this inrestigation, as well as independent inrestigation by others who are interested in the use of concrete under such conditions, will result in more detailed conclusions and accurate limitations, but the work to date has consistently emphasized certain precautions which should be observed by anyone using cement under such conditions.

\section{CONCRETE BLOCKS}

1. Results to date indicate that materials of good quality and proper workmanship are of great importance in the production of concrete which is to be exposed to alkali soils and waters.

2. Action noted on surfaces of concrete blocks of best quality after one year exposure in sulphate waters has in most cases been progressire, depending upon conditions of exposure.

3. Extent and rapidity of disintegration in sulphate waters depends upon concentration of salts in waters to which the concrete is exposed.

4. In blocks containing reinforcing rods disintegration appears to be aided and accelerated in some cases by corrosion of embedded 
steel and consequent cracking of the concrete, as has been observed in some reinforced concrete structures exposed to sea water.

5. Structures placed in alkaline soils or exposed to alkaline seepage waters should be given all possible protection by drainage.

6. Seepage waters and alkaline soil conditions may be encountered which will disintegrate concrete of the best quality, and proper consideration should be given to soil and water conditions and protection by drainage and other means when it is proposed to expose concrete structures to conditions similar to those in which these test blocks have been placed.

7. Alkali salts are not uniformly distributed throughout the soil or large bodies of seepage waters, and it will be difficult to determine in advance the concentrations to which a structure may later be exposed. A systematic scheme for sampling soils will furnish information as to the quantities and types of salts available for solution, while analyses of seepage waters will indicate the concentrations present at the time of sampling. Disintegration is brought about only by those salts which are in solution as indicated by analyses of water samples, while the soil analyses merely represent reserve supplies which may bring about changes in the existing solutions with changing conditions of rainfall, flooding, etc. The problem of drawing conclusions as to the most serere conditions which may occur becomes more difficult when the source of supply of the salt is through underground seepage from some distant point.

8. For the same concentration of soluble salts and for the same aggregates resistance of mass concrete to alkali action appears to vary with cement content or richness of mix, within the limits employed in these tests.

\section{CEMENT DRAIN TILE}

1. The use of concrete tile in soils containing alkali salts of the sulphate type in considerable quantities is hazardous, in view of the fact that some specimens of the best quality of drain tile have been disintegrated during an exposure of less than six years.

2. Porous or permeable tile, due to the use of lean mixtures or relatively dry consistencies, are subject to disintegration in sulphate waters of relatively low concentrations.

3. Dense tile of the best quality exposed to sulphate waters are under certain not well defined conditions subject to disintegration depending among other things upon concentration of salts in seepage water and alkali and moisture conditions in the soil immediately surrounding the tile.

4. Disintegration may be manifested in sulphate waters by physical disruptions caused by expansion resulting from the crystallization of salts in the pores, but it is more likely due to chemical action 
between the salts in solution and the constituents of the cement. In the case of dense tile of low permeability exposed to sulphate waters, disintegration may occur at or just inside the surface skin and progress into the wall of the tile.

5. A thin outer skin of apparently unaffected concrete is apparent in the case of disintegration of the best quality of tile. While this relatively thin layer may be either immune to attack by salts in solution, or, perhaps, be rery slowly attacked, results indicate that this carbonated coating is not in itself waterproof, and alkali water may pass through this coating into the mass.

6. In sulphate waters with a concrete or mortar of given quality the disintegrating effect seems to rary with the concentration of the solution.

7. Tile made by the process commonly used, which allows the remoral of forms immediately after molding, are more susceptible to disintegration where exposed to sulphate soils or waters than are tile made of wetter consistency which requires their retention in the molds for a period of hours.

8. The use of hand-tamped tile of plastic consistency, such that the jacket can be remored immediately after molding, can not be recommended for use in sulphate soils and waters. Tile of plastic consistency, molded in the packer-head type of machine, are more resistant to alkali action than the hand-tamped tile, but the best quality of packer-head machine tile hare been affected in waters of high salt concentration.

9. Steam-cured tile show no greater resistance to alkali action than tile which are cured by systematic sprinkling with water.

10. Tile made of sand cement have less resistance to alkali action than tile made of Portland cement of the same proportions.

11. The tar coating as used was not effective in preventing the absorption of alkali water into the walls of the tile.

12. The cement-grout coating is not effective in preventing the absorption of alkali water.

13. No adrantage was found in introducing ferrous sulphate into the cement inixture. The use of this material resulted in a reduction of the crushing strength of the tile.

14. If cement drain tile are to be used in soils and waters containing 0.1 per cent or more salts of the sulphate type, their installation should be preceded by an examination of subsurface alkali conditions. Decision as to the adrisability of using cement drain tile should be based upon thorough examination of subsurface conditions and quality of product which it is proposed to use and upon a comparison of the data so obtained with the data presented in this report. Such an examination may indicate portions of an area 
where the use of cement tile should be avoided. Quantities of alkali salt present can be determined by chemical analyses of the soils. Concentrations to which tile may be exposed can be determined by chemical analyses of the ground waters. In drawing conclusions allowance must be made for the constantly changing concentrations of alkali in the seepage water, which at times may differ as much as several hundred per cent in adjacent areas. There can be no assurance that the concentrations found at any time are the maximum to which the tile will ever be exposed. Quality of cement drain tile can best be measured by permeability tests. With other conditions equal, tile of lowest permeability will be the most durable. There appears to be little definite relation between permeability and the related factors of porosity, absorption, and density.

15. The strength of the tile after being subjected to the action of the sulphate salts is not a true measure of the extent of the attack. Apparently the salts crystallized in the pores give a considerable amount of compressive strength to specimens even when disintegration is very marked.

\section{APPENDIXES}

\section{APPENDIX A.-ABSORPTION TESTS ON TILE OF SERIES 1 TO 21}

The results of absorption tests on samples of the tile in storage at Ames, Iowa, are shown below. These tests were conducted by W. J. Schlick, drainage engineer, Iowa State College, in 1920, using portions of tile remaining after the 1919 crushing tests of the Ames storage tile were completed. Absorption values were determined by boiling specimens 5 hours as specified in the A. S. T. M. specification for tests of drain tile and also by immersion for 72 hours in water at room temperature. Generally the value found for immersion is considerably less than for the five-hour boil. It is worthy of note that the tile of highest impermeability which have shown greatest resistance to alkali action show practically the same quantities absorbed by the two methods. The differences in permeability are in part due to greater cement content in some cases, but generally to the use of a greater quantity of mixing water than is commonly used in the manufacture of drain tile in the packer-head type of machine. It is possible that further study will indicate the rate of absorption to be a measure of the durability in alkali waters within the ranges of consistencies employed in the manufacture of tile and for equal cement contents. The absorption value obtained is alone of little value in indicating quality, since the poorest and best tile have practically the same absorption percentage. These tests suggest that permeability rather than porosity or density may be a criterion of resistance to alkali action.

\section{APPENDIX B.-THE PRESENCE AND DISTRIBUTION OF SALTS IN THE SOIL AND THEIR ACTION ON CEMENT AND CONCRETE}

The foregoing investigation has to date dealt mainly with observation and tests of mortar and concrete specimens in the form of drain tile and concrete blocks which have been exposed to alkali soils and waters in various districts of the West. Such laboratory work as has been carried on has been in connection with physical tests of cement, aggregates, and concrete and mortar test specimens, together with chemical analyses of materials used, and samples of soils, 
waters, and alkalies to which the specimens have been exposed. A discussion of the conditions which have brought about the necessity for studies of the effect of alkali on concrete, together with a summary of the results of other investigations, may be of interest.

Long exposure of rocks to the elements has resulted in their disintegration to form soil through which are found distributed the soluble salts of sodium, calcium, and magnesium. Years of rainfall in the humid regions have resulted in the leaching of the greater portion of the soluble salts from the soil, but in the arid and semiarid regions of the West relatively small quantities have been removed except where by irrigation or other means large quantities of water have been available with good natural drainage conditions. The accumulation of these salts in those regions is usually referred to as "alkali deposits." What is known as "white" alkali is usually a mixture of the sulphates and chlorides of sodium, calcium, and magnesium, while "black" alkali, so called because of its tendency to dissolve vegetation or organic matter and stain the surface of the soil a brown or black color, contains a large percentage of sodium carbonate together with smaller amounts of the white alkali. The white alkali is the most widely distributed type, and experience has shown that it is more injurious to concrete.

Disintegration of concrete structures is usually noted and is most marked at and just above the ground line and will vary with soil water conditions. Where the alkali water level is constantly below the limits of soil capillarity, disintegration may be entirely confined to portions below the ground surface. Disintegration at or near the surface is, no doubt, accelerated by frost action and alternate wetting and drying, but these effects are only contributory.

The appearance of concrete affected by alkali salts varies with the quality of the concrete, the concentration of the solution, and duration and condition of exposure. With good quality concrete of low premeability the first stage of the action is marked by the flaking or shelling off of the surface skin of neat cement of rich mortar, exposing sand grains and aggregate particles. As the action continues larger aggregate particles are exposed, and the new surface has the appearance of being abraded, and white deposits of salts appear in the pores. In the last stage the material loses its identity as concrete and appears to be a mixture of aggregate particles distributed throughout a soft, white, putty-like paste. This change may be accompanied by a considerable increase in volume. Disintegration of concrete of low permeability is essentially a sulface action which gradually progresses into the mass. In some cases the outer skin appears to be immune to attack, but it does not entirely prevent the penetration of alkali water which in reacting with the inner portion causes swelling which shatters the surface skin.

Rapidity of penetration of the action is dependent upon permeability of the concrete and concentration of salt in solution. Chipping away the affected portion will usually reveal concrete just beyond which is apparently unaffected.

In the case of permeable concrete or mortar mixtures of the type commonly used in hand-tamped drain tile or sewer pipe, a somewhat different and more rapid action occurs. The comparative ease of penetration of alkali water through the wall exposes a large volume of cement to the action of the salts and a rapid swelling and increase of volume results, the whole mass finally breaking down to form the typical white putty-like paste.

The deterioration of concrete in alkali soils when first noted and studied was generally ascribed to the use of poor aggregates or improper methods of mixing and placing concrete, and it was believed that disintegration was brought about merely by the crystallization of alkali salts in the pores of the concrete. Since these salts in crystal form occupy a greater volume than in solution, it was thought that the mechanical forces exerted were sufficient to disrupt the mass and fully 
account for the disintegration noted. If this theory were true, disintegration could be avoided by producing concrete of low permeability which would prevent appreciable quantities of salt from entering. Laboratory investigation has shown that disintegration may not be due to disruptive forces exerted by the salts in crystallizing, but rather to the chemical reaction between salts in solution and constituents of the cement. Disintegration can be induced by chemical action, and any disruption which may occur under certain conditions as the result of crystallization may be secondary.

During the process of hardening of concrete calcium hydrate is formed, and it is this material which is most readily attacked. The sulphates of sodium and magnesium in alkali waters react with the calcium hydrate to form calcium sulphate and sodium and magnesium hydrates. The part played in the process of disintegration by these newly formed compounds is not well understood and no doubt varies with the permeability of concrete and quantity and movement of the alkali waters, but the final effect can not be disputed since the changes produced in the laboratory under controlled conditions have been verified by the inspection of good quality concrete which has been exposed to somewhat similar conditions in the field.

As a result of investigations in various chemical laboratories in which the solvent action of various salt solutions on cement and concrete has been measured, certain definite conclusions have been drawn. Studies made by Burke and Pickney at Montana State Agricultural College and reported in Bulletin No. 81 may be summarized as follows:

The disintegration of cement by alkali salts is principally due to reaction between these salts and the calcium hydroxide necessarily present in set cement. As a result of these reactions relatively insoluble new compounds are formed in the body of the cement structure. These new compounds have greater weight and require greater space than the $\mathrm{Ca}(\mathrm{OH})_{2}$ replaced. New compounds force apart the particles of cement, thus weakening or breaking the binding inaterial.

The results of a laboratory investigation at the University of Wyoming Experiment Station, reported by Steik in Bulletin No. 122, lead to the conclusion that "The ultimate cause of the disintegration of cement is by the alkalies forming compounds with the elements of the cement which subsequently are removed from the cement by solution."

The results of an extensive laboratory and field investigation of the action of the salts in sea water on cement, conducted by Bates, Phillips, and Wig, of the bureau, are reported in B. S. Technologic Paper, No. 12. Their work indicated that in the presence of sea water and similar sulphate-chloride solutions "the most soluble element in the cement is lime. If the lime of the cement is carbonated, it is practically insoluble."

Thus, it is seen that such investigations as have been carried on in the chemical laboratories have led to the agreement that certain constituents of the cement are attacked and react with the salts in solution. It has been found possible in the laboratory by artificial solutions to destroy almost completely test pieces of Portland cement mortars and concretes. It was also believed that laboratory conditions were probably more severe than exposure conditions which might ordinarily be encountered in the field. For the purpose of studying the behavior of mortars and concretes of known and good quality when exposed to the normal alkali soil conditions, the investigation described in detail in the foregoing pages was planned and started in 1913 . The results, so far obtained, indicate that field conditions may be fully as severe and destructive to good quality concrete as were the early experiments carried out under laboratory conditions.

Wasmington, April 29, 1925. 